\title{
DETERMINANTS OF FOOD INSECURITY AMONG VULNERABLE WHITE AND LATINO HOUSEHOLDS: CONTEXTUALIZING THE IMPACT OF SOCIODEMOGRAPHIC AND HOUSEHOLD-LEVEL FACTORS
}

\author{
A Thesis \\ presented to \\ the Faculty of the California Polytechnic State University, \\ San Luis Obispo \\ In Partial Fulfillment \\ of the Requirements for the Degree \\ Masters of Science in Agriculture \\ with a specialization in Food Science and Nutrition
}

By

Alexandra Lund

May 2013 
(C2013

Alexandra Lund

ALL RIGHTS RESERVED 


\section{COMMITTEE MEMBERSHIP}

TITLE: Determinants of food insecurity among vulnerable White and Latino households: Contextualizing the impact of sociodemographic and household-level factors
AUTHOR:
Alexandra Lund

DATE SUBMITTED: $\quad$ May 2013

COMMITTEE CHAIR: $\quad$ Aydin Nazmi,PhD, Assistant Professor, Food Science and Nutrition Department and Interim Director of STRIDE, California Polytechnic State University, San Luis Obispo

COMMITTEE MEMBER: Ann Yelmokas McDermott, PhD, MS, LDN, Assistant Director, Johns Hopkins Global Center on Childhood Obesity, John Hopkins University Bloomberg School of Public Health

COMMITTEE MEMBER: Dawn Neill, PhD, Assistant Professor, Social Sciences Department, California Polytechnic State University, San Luis Obispo 


\title{
ABSTRACT
}

Determinants of food insecurity among vulnerable White and Latino households: Contextualizing the impact of sociodemographic and household-level factors

\begin{abstract}
Alexandra Lund
Household-level characteristics have been shown to be associated with food insecurity but studies among vulnerable populations are sparse. A food security assessment was developed to determine food security and collect sociodemographic and household level data across San Luis Obispo County. The assessments were administered to vulnerable groups through interviews at multiple sites across the County. Three household characteristics (marital status, number of children in the household and number of workers in the household) were examined in this analysis. A total of 808 surveys were collected, $69 \%$ in English and 31\% in Spanish. Through ethnicity-stratified sequentially adjusted logistic regression models, the association between food insecurity and household characteristics were tested, controlling for sociodemographic, economic and other potentially mediating variables. In the fully adjusted model for Hispanic/Latino households, associations were observed with number of children in the household and workers in the household, but confidence intervals were wide. In the fully adjusted model for White households, marital status was weakly associated with food insecurity. In both groups, per capita monthly income was strongly associated with food insecurity. Several interrelated household and individual level variables determined a households food security status. Because of this complexity, comprehensive social and economic changes are needed to improve food security in California and the rest of the United States. Also, different processes associated with race/ethnicity and coping strategies with regard to food insecurity should be considered when designing studies, planning policies, and conducting interventions.
\end{abstract}

Keywords: food security, household characteristics, Latino, Hispanic, marital status, children, workers, employment, type of employment, income 


\section{TABLE OF CONTENTS}

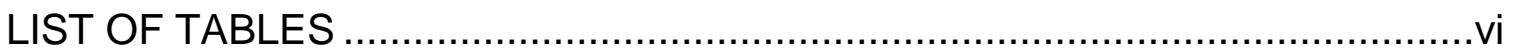

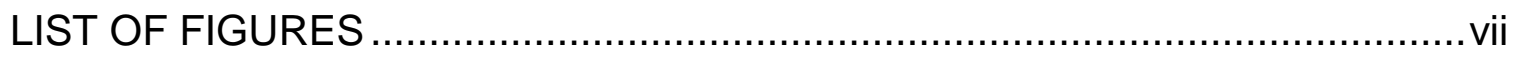

CHAPTER 1: INTRODUCTION

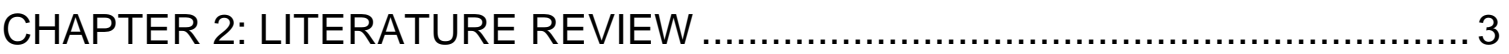

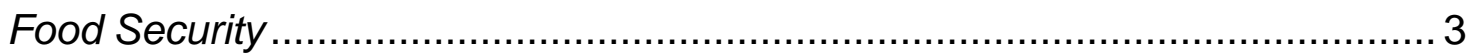

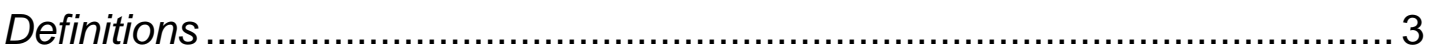

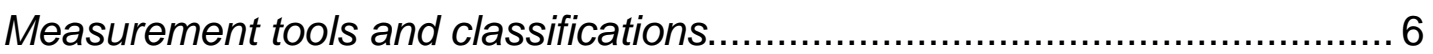

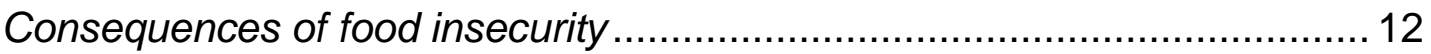

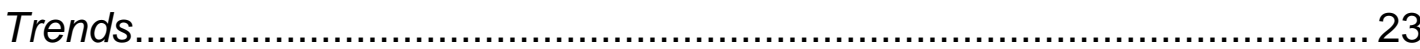

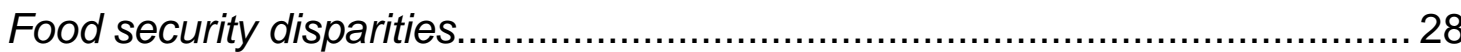

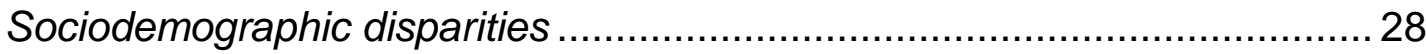

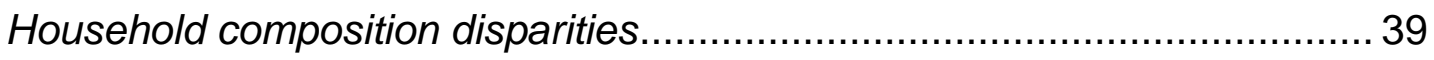

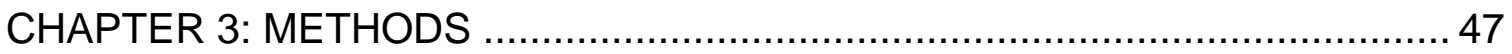

Hunger-Free Communities Project........................................................... 47

Food security assessment survey development.............................................. 48

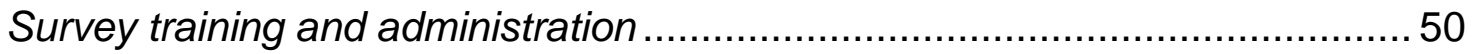

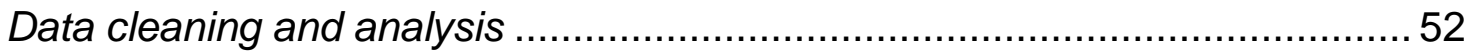

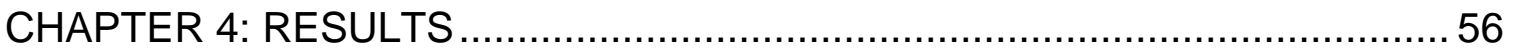

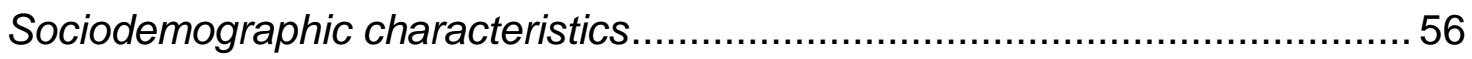

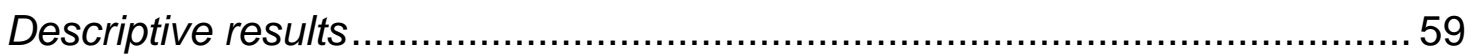

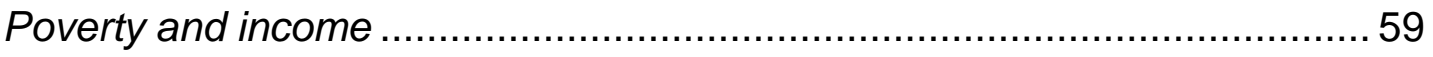

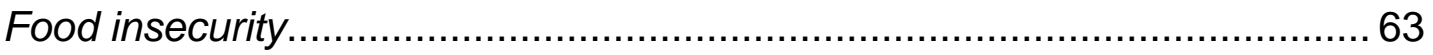

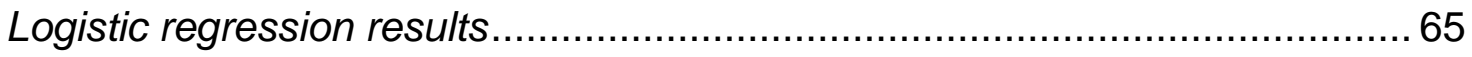

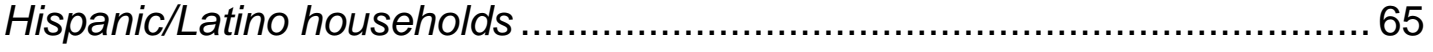

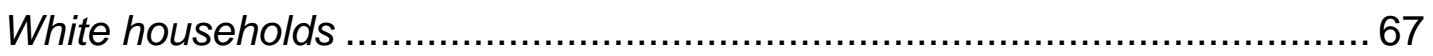

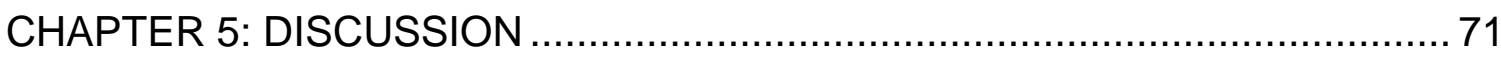

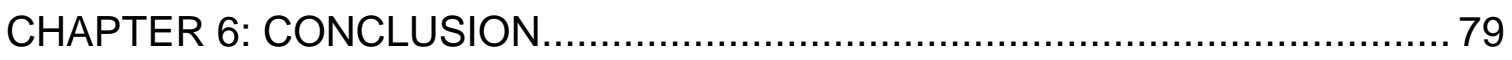

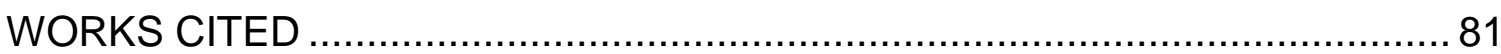

APPENDIX A: Food security assessment survey (English version) .................... I

APPENDIX B: Food security assessment survey (Spanish version) ................... VI

APPENDIX C: Informed consent forms (English and Spanish) ......................... XI

APPENDIX D: Food Security Assessment Survey Training Manual................. XIV

APPENDIX E: Modified variables for statistical analysis .............................. XVIII 


\section{LIST OF TABLES}

Table

Page

2-1: USDA food security labels old and new and their associated descriptions. 10

2-2: Questions in the 6-item household food security survey module

2-3: Adjusted association between food insecurity and obesity among women in the United States.

2-4: Prevalence of food insecurity (low and very low) among low-income Households in California 2007 and 2009, by County in ranking order.

2-5: Factors affecting food security status among Latino families by ecological systems levels. .34

3-1: Food security assessment survey sites and number of visits .50

4-1: Mean \pm SD or proportion of sociodemographic characteristics of vulnerable San Luis Obispo County households, overall and by ethnicity.

4-2: Proportion of households with incomes less than or equal to $130 \%$ of the Federal Poverty Level according to marital status, stratified by ethnicity....

4-3: Correlation matrix of household income (total and per capita) and education.

4-4: Proportion of households with incomes less than or equal to $130 \%$ of the Federal Poverty Level according to number of workers in the household, stratified by ethnicity.

4-5: Proportion of households with incomes less than or equal to $130 \%$ of the Federal Poverty Level according to food security classification, stratified by ethnicity.

4-6: Sequentially adjusted logistic regression models for the associations between household characteristics and food insecurity (OR 95\% Cl) (Hispanic/Latino).

4-7: Sequentially adjusted logistic regression models for the associations between household characteristics and food insecurity (OR 95\% Cl) (White). 


\section{LIST OF FIGURES}

Figure

Page

2-1: Energy density-cost curve showing the relation between diet costs, dietary energy density, and energy intakes

2-2: Trends in the prevalence of food insecurity and very low food

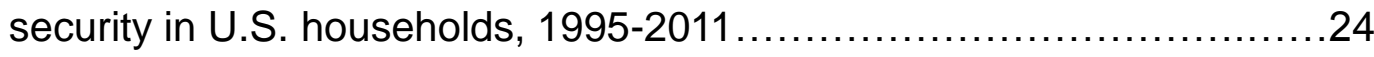

2-3: Percentages of average expenditures of major components of

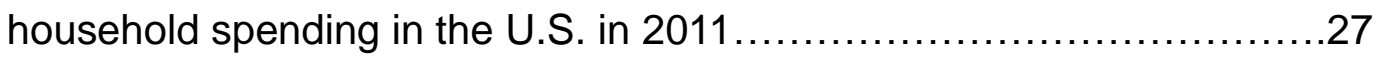

2-4: Ecological framework depicting the multiple influences on what and how people eat.

2-5: Percent distribution of the Hispanic population by state: 2010

3-1: Hierarchical conceptual framework for the relationship between examined variables and food insecurity

4-1: Proportion of households in each food security category, overall and by ethnicity..... .58

4-2: Mean household monthly income according to number of children in the household, stratified by ethnicity.

4-3: Mean per capita monthly income according to highest education level completed, stratified by ethnicity.

4-4: Proportion of households with incomes less than or equal to $130 \%$ of the Federal Poverty Level according to type of work, stratified by ethnicity..... 63 


\section{CHAPTER 1: INTRODUCTION}

Over the past decade, prevalence of food insecurity has increased throughout the United States. States such as California, hit hardest by the economic recession, have especially experienced increases in food insecurity. The high housing prices and cost of living further intensify disparities in food security among vulnerable populations in areas such as San Luis Obispo County. Growing rates of food insecurity are of critical concern given the potentially serious health and developmental consequences of not having enough food. Chronic food insecurity within certain populations perpetuates socioeconomic inequalities and limits the potential for social and economic advancement within communities.

There are many forces that are responsible for shaping the health of a household. While individual behaviors are important, the physical and social environment in which individuals and households function, may constrain or expand opportunities for optimal food security. Examining the association between household-level characteristics and food insecurity could give policy makers and public health professionals more insight into processes by which hunger manifests and potential coping capacities within at-risk households. Understanding how different variables affect food security status could help policy makers and public health officials to plan strategies that address the complex and inter-related determinants of food insecurity.

Several studies have explored these determinants among populations; however, research specifically among vulnerable populations is lacking. A 
growing vulnerable Latino population in California also demands that research specifically within ethnic subgroups be collected. Therefore, the objective of this study was to determine the association between household characteristics (marital status, number of children in the household and number of workers in the household) and food insecurity among vulnerable Hispanic/Latino and White households in San Luis Obispo County. It is hypothesized that these household characteristics will be associated with food insecurity among vulnerable households. 


\title{
CHAPTER 2: LITERATURE REVIEW
}

\author{
Food Security
}

\section{Definitions}

Food security is an inherently unobservable and complex concept. Despite prevalent literature and growing research on the subject, it remains an ambiguous topic that has eluded a precise definition. Several accepted definitions of food security exist and are utilized in scientific literature. The United States Department of Agriculture (USDA) definition is one of the most commonly used definitions, and the one that will be referenced in this review. The USDA definition asserts that "food security exists when all people at all times have enough food for an active, healthy life" (Coleman-Jensen \& Nord, 2012). If food security involves having enough food, then food insecurity involves uncertain access to enough food for an active, healthy life. Generally, food security can be examined at the national and global levels when approaching population level concerns, or at the household and individuals level when investigating behavior. Household level food security will be the focus of this analysis. Household food security expands the USDA definition to include all members of a household having enough food. An assessment of household food security determines whether the entire household gets enough food and if the nutritional needs of all household members are met (Coleman-Jensen, Nord, Andrews, \& Carlson, 2012).

Food security is assessed by two fundamental factors: food availability and food accessibility, both of which will be presented in the context of the 
household. Food availability refers to having sufficient quantities of food available on a consistent basis (Food and Agriculture Organization of the United Nations, 2006). Food availability is dependent upon whether food stores, or food patches of any sort are present in a given area and if specific foods exist at those locations. For example, many urban neighborhoods and rural towns are considered food deserts, meaning that they do not have adequate supermarkets or grocery stores and may be served only by fast food restaurants and convenience stores (United States Department of Agriculture, Economic Research Service, 2013).

Food accessibility refers to having sufficient resources to obtain those foods (Food and Agriculture Organization of the United Nations, 2006). Access is essential to food security because although food may be available to a given household, if that household cannot access food, it will remain food insecure. Access to food is determined by multiple factors, including purchasing power, various community characteristics (e.g. transportation), and government and private assistance programs (Wehler, Scott, \& Anderson, 1992). For example, limited produce may be stocked at a grocery store in a low-income community but if the cost of those items is high, then individuals may not be able to purchase them on a limited food budget. As characterized by the USDA (2012b), "food security includes at a minimum: 1 ) the ready availability of nutritionally adequate and safe foods, and 2) an assured ability to acquire acceptable foods in socially acceptable ways (i.e., without resorting to emergency food supplies, scavenging, stealing, or other coping strategies)." 
The fact that many Americans lack adequate availability of, or accessibility to food, while others excessively consume and even waste food, reflects a deep seeded issue of distributive justice, or how a society allocates benefits and burdens in a just and moral way (Hsu, Anen, \& Quartz, 2008). Many important human rights analyses have outlined the right to adequate food for all people (Kent, 2005). To assert that food insecurity is not simply an involuntary lack of food but rather a result of entitlement failure further defines food security as a human rights issue. In other words, access to adequate nutrition depends upon political and legal systems that allow people to meet their basic needs (Chilton \& Rose, 2009). While the definition of food insecurity accepted by the USDA, and the one utilized in this research, simply defines a condition, many other definitions of food security include the concept of the right to food and imply some governmental obligation to uphold a state of being among individuals. For example, The United Nations utilizes the definition for "right to food," which asserts "the right to have regular, permanent and unrestricted access, either directly or by means of financial purchases, to quantitatively and qualitatively adequate and sufficient food corresponding to the cultural tradition of the people to which the consumer belongs, and which ensure a physical and mental, individual and collective, fulfilling and dignified life free of fear" (Ziegler, 2002).

Several other terms are associated with the complexities of food security. Hunger is a physiological sensation associated with insufficient food intake (American Dietetic Association, 1990). Hunger is closely related to food insufficiency, meaning that an individual or household sometimes or often does 
not have enough food to eat (Vozoris \& Tarasuk, 2003). While hunger and food insufficiency may imply food insecurity, the terms are not mutually inclusive and should not be used interchangeably. Shortfalls in consumption may manifest in undernutrition or malnutrition, which are also potentially, but not necessarily, consequences of food insecurity. Undernutrition is caused by an inadequate intake of dietary energy; whereas malnutrition arises from deficiencies in specific nutrients or from an inappropriately balanced diet (Shetty, 2003).

\section{Measurement tools and classifications}

Due to the complex nature of food security, it is not only difficult to define but also to objectively measure. Measurement and monitoring are important in identifying and understanding the basic aspects of well-being of the population and to identify population subgroups or regions with disproportionally compromising conditions (Bickel, Nord, Price, Hamilton, \& Cook, 2000). Food insecurity varies through a continuum of successive stages as the condition becomes increasingly severe within a household. In the first stage of insecurity, members of a household feel anxiety about the sufficiency of their food and make adjustments to their diet and food budget. As the situation becomes worse, food intake in adults is reduced and they may experience physical hunger. In the third and most severe stage of food insecurity, children also suffer from reduced food intake. Each stage consists of a range of experiences and responses to these conditions. A variety of indicators are needed to fully capture the abstruse issues involved (Bickel, Nord, Price, Hamilton, \& Cook, 2000). 
In response to growing reports of increased dependency on emergency food sources in the early 1980 s, several organizations began developing measurement tools for assessing food security (Haering \& Syed, 2009). In 1984, The President's Task Force on Food Assistance report noted the absence of an agreed-upon measurement and method to estimate the extent of food insecurity (as cited in Carlson, Andrews, \&Bickel, 1999). Researchers increased efforts to develop a survey method that would reliably and consistently document food insecurity. Furthermore, in the early 1990s the USDA and the Department of Health and Human Services (HHS) initiated the US Food Security Measurement project, which sought to develop a uniform national measurement that would produce equivalent data for comparable research at the national, state and local levels (Nord \& Hopwood, 2007). Content from existing tools was drawn upon, including work from the Community Childhood Hunger Identification Project (CCHIP) and Cornell University's Department of Nutritional Sciences (Radimer, 2002). Eighteen questions were selected to form the US National Household Food Security Survey Module (HFSSM), also referred to as the Household Food Security Measure, with the same acronym (Haering \& Syed, 2009). Questions in the module were chosen to assess all components of food security (quantity, quality, psychological acceptability and social acceptability) at the household level, in both adults and children (Radimer, 2002). The classification from the HFSSM represents the condition of household members as a group but not necessarily the condition of a specific household member. While the HFSSM is only one of many measurement tools, it will be the instrument further elaborated 
on, in part because it is most frequently used in national data sets. It will be referenced in this review also because it was the tool used in data collection.

The questions in the HFSSM are posed as either 1) a statement, where the respondent is asked if in the past 12 months the statement is often, sometimes or never true, 2) direct yes or no questions, or 3) questions related to the frequency a particular event. Four kinds of situations are covered by the 18 questions: 1) anxiety or perception that household food budget or food supply are inadequate, 2) perceptions that the food eaten by adults or children was inadequate in quality, 3) reported instances of reduced of reduced food intake or consequences, for adults, and 4) reported instances of reduced food intake or its consequences for children (Haering \& Syed, 2009). The answers to each question are scored based on affirmative answers and combined into a single overall measure called the food security scale. This is a continuous, linear scale which measures the degree of food insecurity experienced by a household in terms of a single numerical value. The Scale values range from zero, a household that has not experienced any of the conditions covered by the module questions and has answered all negatively to all questions, to ten, a household that has experienced all of them and has answered affirmatively to all questions. The unit of measure used for the scale is a matter of convenience and is not based on a point-per-question scoring system. The statistical methods that underlie the food security scale are highly complex and produce a continuous measurement which is then adapted to the categorical measurement values (Bickel, Nord, Price, Hamilton, \& Cook, 2000). 
A household's raw score places it in one of four categories. Placement into categories depends on the raw score from the questionnaire and the presence or absence of children. From the initial publication of the Guide to Implementing the Core Food Security Module in 1997 up until 2006, the four categories associated with the HFSSM were food secure, food insecure without hunger, food insecure with hunger (moderate), food insecure with hunger (severe). In 2006 a panel convened by the Committee on National Statistics (CNSTAT) of the National Academies conducted a review of the food security measurement methods and recommended that the USDA make a clear and explicit distinction between food insecurity and hunger. They encouraged the USDA to consider alternative labels that conveyed the severity of food insecurity without explicitly using the word "hunger" (Nord, 2012). The USDA later introduced the following new labels (Table 2-1). The new labels are currently used in classifying levels of food security.

A variety of statistical tests for reliability, including tests specific to the Rasch model and several tests commonly used for scales developed through linear analysis have shown that the food security scale has good reliability (Hamiliton, Cook, Thompson, Buron, Frongillo, Olson, \& Wehler, 1997). The scale scores relate significantly to the poverty income ratio, weekly food expenditures and the USDA food sufficiency measure as expected, indicating good validity (Ohls, 1999). Research has also shown that the scale is highly stable over time and robust among different ethnic groups. (Tarasuk \& Beaton, 1999) and (Derrickson \& Anderson, 2000). 
Table 2-1: USDA food security labels old and new and their associated descriptions (Coleman-Jensen \& Nord, 2012).

\begin{tabular}{|c|c|c|c|}
\hline $\begin{array}{c}\text { General } \\
\text { Categories } \\
\text { (old same as } \\
\text { new) }\end{array}$ & Old Labels & New Labels & $\begin{array}{l}\text { Description of Condition (as } \\
\text { listed for new labels) }\end{array}$ \\
\hline \multirow[b]{2}{*}{ 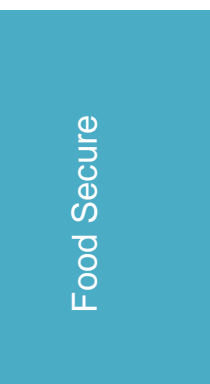 } & \multirow[t]{2}{*}{ Food Secure } & $\begin{array}{l}\text { High Food } \\
\text { Security* }\end{array}$ & $\begin{array}{l}\text { No reported indications of food- } \\
\text { access problems or limitations }\end{array}$ \\
\hline & & $\begin{array}{l}\text { Marginal Food } \\
\text { Security* }^{*}\end{array}$ & $\begin{array}{l}\text { One or two reported indications- } \\
\text { typically of anxiety over food } \\
\text { sufficiency or shortage of food in } \\
\text { the house. Little or no indication } \\
\text { of changes in diets or food } \\
\text { intake. }\end{array}$ \\
\hline \multirow{2}{*}{ 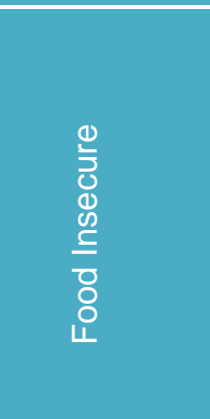 } & $\begin{array}{l}\text { Food Insecure } \\
\text { without Hunger }\end{array}$ & $\begin{array}{l}\text { Low Food } \\
\text { Security }\end{array}$ & $\begin{array}{l}\text { Reports of reduced quality, } \\
\text { variety, or desirability of diet. } \\
\text { Little or no indication of reduced } \\
\text { food intake }\end{array}$ \\
\hline & $\begin{array}{l}\text { Food Insecure with } \\
\text { Hunger (Moderate) } \\
\text { Food Insecure with } \\
\text { Hunger (Severe) }\end{array}$ & $\begin{array}{l}\text { Very Low } \\
\text { Food Security }\end{array}$ & $\begin{array}{l}\text { Reports of multiple indications of } \\
\text { disrupted eating patterns and } \\
\text { reduced food intake. }\end{array}$ \\
\hline
\end{tabular}

*the 6-item HFSSM does not distinguish between these two categories.

The USDA estimates that the 18-item HFSSM generally requires less than four minutes of survey time to administer, yet in situations where time is constrained or the survey is supplemental, a shortened version of the survey may be more appropriate (Bickel, Nord, Price, Hamilton, \& Cook, 2000). A 6-item HFSSM (Table 2-2) was created using carefully selected questions from the 18item to reliably capture the threshold of identifiable household food insecurity. The 6-item survey does not distinguish between the two sub-labels of food secure (high food security and marginal food security) but it has been shown to closely approximate the three main categories of the 18-item survey (Blumberg, 
Bialostosky, Hamiliton, \& Briefel, 1999). The short version was designed to work equally well for households with and without children, therefore the eight childfocused items were excluded. Because of this exclusion the classification power of the short version is not as strong for households with children. The 6-item survey correctly identified $95.6 \%$ of households with children compared with 99.0\% of households without (Blumberg, Bialostosky, Hamiliton, \& Briefel, 1999). However, the 6-item survey does provide a reliable measure of risk of children's hunger (Bickel, Nord, Price, Hamilton, \& Cook, 2000). Therefore, the short version is a viable tool in place of the complete scale and is recommended instead of randomly selecting questions from the full version (Radimer, 2002). 
Table 2-2: Questions in the 6-item household food security survey module (Radimer, 2002).

"The food that (I/we) bought just didn't last, and (I/we) didn't have money to get more."

Was that often, sometimes, or never true for (you/your household) in the last 12 months?

[] Often true

[] Sometimes true

[ ] Never true

[ ] DK or Refused

"(I/we) couldn't afford to eat balanced meals." Was that often, sometimes, or never true for (you/your household) in the last 12 months?

[ ] Often true

[ ] Sometimes true

[] Never true

[ ] DK or Refused

In the last 12 months, since last (name of current month), did (you/you or other adults in your household) ever cut the size of your meals or skip meals because there wasn't enough money for food?

[] Yes

[] No (Skip next question)

[ ] DK (Skip next question)

[IF YES ABOVE, ASK] How often did this happen-almost every month, some months but not every month, or in only 1 or 2 months?

[ ] Almost every month

[] Some months but not every month

[] Only 1 or 2 months

[] DK

In the last 12 months, did you ever eat less than you felt you should because there wasn't enough money for food?

[] Yes

[] No

[] DK

In the last 12 months, were you every hungry but didn't eat because there wasn't enough money for food?

[] Yes

[] No

[] DK

\section{Consequences of food insecurity}

Food insecurity is a growing public health issue considering its potentially serious health and developmental consequences. The burden of these consequences is concentrated in socioeconomically disadvantaged groups who are already consistently less healthy than their counterparts (Braveman, Cubbin, Egerter, Williams \& Pamuk, 2010) and are more likely to be medically uninsured 
(Reid, Vittinghof, \& Kushel, 2008). Negative outcomes in children are especially troublesome being that poor development and impaired academic performance may diminish national productivity and future human capital, not to mention compounded pre-existing levels of health disparities. Poor nutrition in childhood has also been linked to "programming" effects that may influence chronic diseases in adulthood (Lucas, 1994). The trajectory of many American children is being altered as a result of inadequate nutrition. In other words, consequences of food insecurity are shaping a "way of life" with respect to health and well-being later in life and seriously limiting optimal capability.

Food insecurity creates a heavy burden for individuals, as well as an exorbitant economic cost to the Country. The costs of hunger and food insecurity resulting from, direct health problems and indirect consequences (e.g. lost worker productivity), has been estimated to be approximately $\$ 90$ billion annually in the United States. Additionally, costs per year for nutrition assistance programs, including the Supplemental Nutrition Assistance Program (SNAP), the National School Lunch Program, and others, exceeded $\$ 50$ billion in 2007 (Brown, 2007). Despite the network of costly assistance programs, rates of food insecurity are increasing (Coleman-Jensen, Nord, Andrews, \& Carlson, 2012). A comprehensive view of the nutritional and non-nutritional consequences associated with food insecurity may help policy makers get a better grasp of the severity of this issue, in terms of medical, societal and economic consequences. 


\section{Nutritional outcomes}

Food insecurity is associated with suboptimal food and nutrient intake, as well as risk for specific nutrient deficiencies (Kaiser \& Townsend, 2005). In an evaluation of the National Health and Nutrition Examination Survey (NHANES) III, food insecure adults had less healthy diets, based on consumption of grains, vegetables, fruits, milk, meat, total fat, saturated fat, cholesterol, sodium and food category variety (Bhattacharya, Currie, \& Haider, 2004). Furthermore, comparisons of consumption between food secure and food insecure women with children showed that the frequency of fruit and vegetable consumption declined significantly as food insecurity status worsened. Researchers also found that significantly fewer food insecure persons consumed the recommended five daily servings of fruits and vegetables as compared to those who were food secure (3.7\% and 9\% respectively) (Kendall, Olson, \& Frongillo, 1996). Based on changes in overall diet, primarily in fruit and vegetable consumption, food insecure individuals may be exposed to micronutrient deficiencies and therefore at risk of serious health problems.

Micronutrient adequacy is crucial for overall health in all age groups but it is especially important for infants and toddlers who are at critical stages of vital organ development and for elderly persons who may have problems with nutrient absorption. All low levels of vitamins and minerals are cause for concern but iron deficiency is particularly harmful due to its role in cognitive development in children. In a cross-sectional sample of caregivers of children less than 36 months of age, food insecure children were found to be 2.4 times more likely to 
be Iron Deficient with Anemia (IDA) compared with food secure children (95\% Cl 1.1-5.2). The researchers speculate that IDA may be one of the physiological mechanisms between child food insecurity and documented psychosocial and biophysical consequences (Skalicky, Meyers, Adam, Yang, Cook, \& Frank, 2006). Another analysis of data from the NHANES III found that food insecure elderly adults were less likely to consume foods rich in iron, zinc, magnesium, riboflavin, vitamin B-6, vitamin B-12 and niacin compared to food secure elderly adults (Lee \& Frongillo, 2001)

Several studies have shown that food insecurity is associated with changes in dietary intake (Kaiser \& Townsend, 2005), whereas others have documented the mediating affect that caregivers' compromised diet can have on children's diet. The phenomenon of "child preference" is the management of household food such that at low levels of food security, adults sacrifice their own food to maintain adequate levels for children (Rose, 1999). A National Longitudinal Study of Children and Youth showed that when food was scarce, $34 \%$ of caregivers skipped meals or ate less, as opposed to only $5 \%$ of their children (Mclntyre, Conner, \& Warren, 2000). The successive stages of food insecurity explain that only at the low stages of food insecurity are adjustments made to adult's diets, and only at the very lowest stage do children suffer from reduced food intake (Bickel, Nord, Price, Hamilton, \& Cook, 2000). In a survey of low-income mothers, predominantly single-parents, $52 \%$ of respondents said that they deprived themselves of food to feed their children (Badun, Evers, \& Hooper, 
1995). Examining the diet of multiple household members uncovers a deeper understanding of the dynamics that food insecurity exacts on a family unit.

Curiously, although adults have been shown to compromise meals or quantity of food, they may still get enough, or even excess, energy (i.e.

kilocalories) from food insecure diets. After examining dietary information from a 24-hour recall included in the 1999-2002 NHANES, researchers concluded that mean energy intake in adult women did not differ between those who were food secure and food insecure $(1,896.5 \mathrm{kcal}$, SEM 30.2 and 1,902.7kcal, SEM 70.9 respectively), rather types of foods and meal behaviors differed. Food insecure adults consumed fewer but larger meals and more snacks (Zizza, Duffy \& Gerrior, 2008). Studies have also shown that low-income families purchased lower cost items and spent their limited resources on more fats, sweets and alcohol (Wilde, McNamara, \& Ranney, 2000). Even with the protection of "child preference" feeding, children in a food insecure household have also been shown to have diminished quality of diet. In a cross-sectional, nationally representative sample of households and children, researchers found that when compared to higher-income food-sufficient households, children from low-income food-insufficient households consumed slightly fewer calories and total carbohydrates but had significantly higher rates of cholesterol intake (Casey, Szeto, Lensing, Bogle, \& Weber, 2001). Therefore members of food insecure households may in fact be consuming enough energy but primarily from energydense, nutrient-poor sources, leading to severe nutrient imbalances. 
Malnutrition may exist concurrently in food insecure individuals who are still maintaining adequate caloric intake. Basiotis (1992) confirmed a behavior model in which household members faced with diminishing incomes consume less expensive foods to maintain energy intakes at a lower cost. For example, potato chips offer a substantial number of kilocalories and are very inexpensive. According to the hypothesis that energy density and energy cost are inversely linked (Figure 2-1), consumers undertake a deliberate strategy to save money by first eliminating less energy-dense, high cost foods (Drewnowski \& Specter, 2004). For example, one would have to eat much more broccoli, at a much higher cost to get the same amount of kilocalories as one would from a bag of potato chips. Only when income diminishes still further did households reduce dietary energy to intakes below daily requirements (Basiotis, 1992).

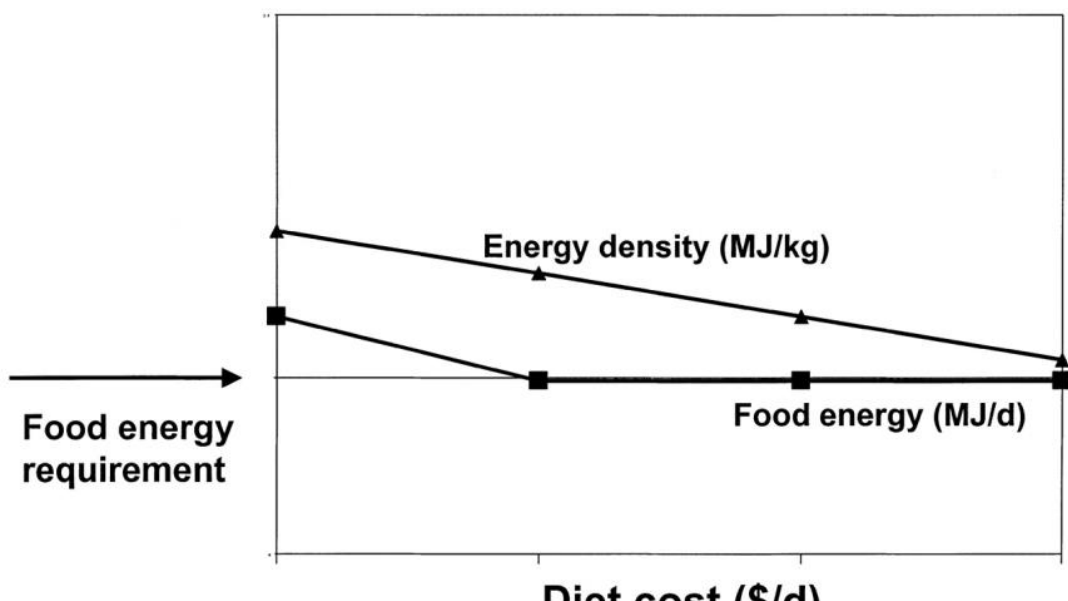

Diet cost (\$/d)

Figure 2-1: Energy density-cost curve showing the relation between diet costs, dietary energy density, and energy intakes. Figure from (Drewnowski \& Specter, 2004). 
Low-income consumers may preferentially choose energy-dense foods; however, their choices may also be the results of changes in the types of foods that are produced and promoted, as well as changes in the social and political mechanisms that have been implemented to address hunger. These prominent forces have established a paradoxical situation in the food insecure population. An examination of current literature regarding the obesity-food insecurity paradox found that there is a relationship between increased body weight and food insecurity in the United States (Dinour, Bergen, \& Yeh, 2007). Although food insecurity is typically associated with a lack of food and obesity with excess, it is possible for the two to co-exist. A cross-sectional analysis of NHANES data from 1999-2000 and 2001-2002, found that after adjusting for confounding variables, women who were food insecure had twice the odds of being obese compared to food secure women, they also had higher mean BMI and mean waist circumferences (Table 2-3) (Seligman, Bindman, Vittinghoff, Kanaya, \& Kushel, 2007). Several other studies corroborate these findings.

Table 2-3: Adjusted association between food insecurity and obesity among women in the United States. Table from (Seligman, Bindman, Vittinghoff, Kanaya, \& Kushel, 2007).

\begin{tabular}{llll}
\hline & $\begin{array}{c}\text { Odds of obesity } \\
(\mathrm{BM} \geq 30), \mathrm{p}- \\
\text { value }\end{array}$ & $\begin{array}{c}\text { Women mean } \\
\mathrm{BMI} \\
\left(\mathbf{k g} / \mathbf{m}^{2}\right), \mathrm{p} \text {-value }\end{array}$ & $\begin{array}{c}\text { Mean waist } \\
\text { circumference } \\
(\mathbf{c m}), \mathrm{p}-\mathrm{value}\end{array}$ \\
\hline Food secure & 1 & 28.9 & 95.5 \\
$\begin{array}{l}\text { Mild food } \\
\text { insecurity }\end{array}$ & $2.0(<0.001)$ & $30.9(<0.001)$ & $98.3(0.001)$ \\
$\begin{array}{l}\text { Severe food } \\
\text { insecurity }\end{array}$ & $1.0(0.9)$ & $28.9(0.8)$ & $95.5(0.8)$ \\
\hline
\end{tabular}

Note. All values are weight to represent the US population. Results are adjusted for age, race/ethnicity, parity, income, educational attainment, occupational physical activity, and leisure-time physical activity. 
Although studies have shown some associations between income and obesity in children (Alaimo, Olson, Frongillo, 2001), associations between food insecurity and obesity are less conclusive. In an analysis of children from kindergarten to third grade, researchers found that children from persistently food insecure households had greater gains in BMI and in weight compared to children from persistently food secure households (Jyoti, Frongillo, \& Jones, 2005). However, other studies found no significant difference in the prevalence of overweight or obesity in different food secure groups (Gundersen, Lohman, Eisenmann, Garasky, \& Stewart, 2008). Rose and Bodor (2006) speculate that inconsistencies in weight status among food insecure individuals of different age

groups could be due to young children being protected by adults in food insecure households, or to the means by which food insecurity affects weight status which may take years to develop.

\section{Non-nutritional outcomes}

Food insecurity has consequences not only in health outcomes but also in academic performance, social skills and mental well-being. Academic incompetencies related to food insecurity are especially distressing since they extend beyond a single test score, to children's ability to learn over a period of time, which may further limit future opportunities (Winicki \& Jemison, 2003). Children from food insufficient families were more likely to score lower on arithmetic tests, have been held back in a grade of school and seen a psychologist at school compared to children from food sufficient households 
(Alaimo, Olson \& Frongillo, 2001). Longitudinal evidence from food secure families, that later become food insecure, further affirms the relationship between child hunger and poor academic performance. Households with children that went from food secure to food insecure showed a significantly smaller improvement in reading and mathematics scores between kindergarten and third grade compared to families that remained food secure (Jyoti, Frongillo \&Jones, 2005). Another study found that starting participation in SNAP during a child's kindergarten to third grade years was associated with academic improvement in reading and math, compared to stopping participation during the same time period, showing the importance of having adequate nutrition and the potentially critical role of nutrition assistance programs (Frongillo, Jyoti, \& Jones, 2006).

Social development issues associated with food insecurity may further compound problems at school. An analysis of children's scores on a Pediatric Symptom Checklist, a parent-reported questionnaire that assessed children's emotional behavior symptoms, found virtually all behavioral and emotional problems were more prevalent in hungry children than those who were not, and that aggression and anxiety had the strongest degree of association. The additive burden of hunger was clear in that hungry children had higher levels of anxious and irritable, aggressive and oppositional behaviors than their lowincome, but not hungry, peers (Kleinman, Murphy, Little, Pagano, Wehler, Regal, \& Jellinek, 1998). Social problems as a result of food insecurity may even extend into later adolescence and young adulthood. Teenagers from food insufficient households were more likely to have seen a psychologist, been suspended from 
school and had difficulties getting along with others even after adjusting for multiple indicators of socioeconomic status, family situation and health(Alaimo, Olson \& Frongillo, 2001).

Issues of mental health have been associated with food insecurity as well. In an analysis of NHANES III data on the prevalence of depression in adolescents, results for food security were the most striking of all characteristics studied. Food insufficient adolescents were four times (95\% Cl 1.6-10.0) more likely to have had chronic depression; two times $(95 \% \mathrm{Cl} 1.2-3.3)$ more likely to have had thoughts of death, three and a half times $(95 \% \mathrm{Cl} 1.7-14.6)$ more likely to have had a desire to die and five times $(95 \% \mathrm{Cl} 1.7-14.6)$ more likely to have attempted suicide. These associations remained significant after several confounding variables were controlled for including family income, suggesting that other indicators of well-being may exert independent influence on depression (Alaimo, Olson \& Frongillo, 2002).

Stress was also a prominent consequence of food insecurity noted in a series of in-depth interviews with food insecure individuals. Stress was expressed through a range of reactions from decreased interest in food as nourishment (e.g. no more desire to cook), to fear and worry over losing custody of children (Hamelin, Habicht \& Beaudry, 1999). Many interviewees described socio-familial consequences and disturbed household dynamics as a result of modified eating patterns. Interviewees cited the lack of food in their household as a source of conflict within normal family relationships, especially between parents and children. Parents recalled being less available to children due to increased 
time spent trying to procure food and having conversational gaps with their children because they were unable to face their incapacity to adequately feed their children (Hamelin, Habicht \& Beaudry, 1999). Parental stress from food insecurity may negatively impact a parent's motivation and ability to improve their family's condition, making it more difficult to move into food security.

Considering that nearly $15 \%$ of American families are food insecure, broader social implications of food insecurity beyond individual level findings are important to consider. Population level chronic food insecurity and its implications (e.g. adolescent depression or disrupted household dynamics) perpetuate socioeconomic inequalities and limit the potential for social and economic advancement within communities. Human capital theory describes the unique capabilities and expertise of individuals as stock of human capital, which is useful to communities as an input into desirable work and activity (Becker, 1975). Human capital can be increased by things such as additional education, training, and investments in a healthy lifestyle. Similarly, it can be diminished by malnutrition, disease and illness, oppression and stress (Becker, 1975). Nutritional and non-nutritional outcomes of food insecurity are all potentially damaging to initial human capital endowments and, with concentrations in particular groups, can be destructive to entire communities. In this framework, adequate nutrition represents a key component in providing communities with adequate stock to invest in desirable work and activities to reduce growing disparities. 


\section{Trends}

Globally, close to one billion people are food insecure with concentrations in the lowest income countries (Food and Agriculture Organization of the United Nations, 2012). The reasons for food insecurity are vast and include complex social, regional and political issues such as chronic or historic poverty, population growth, environmental degradation, war, limited agricultural technology, and disease (Shapouri, Rosen, Peters, Tandon, Gale, Mancino, \& Bai, 2011). The United States has one of the highest Gross Domestic Products in the world and may seem relatively insulated from the problems that perpetuate food insecurity in developing countries. However, millions of households in the United States still suffer from food insecurity and the number of affected households is growing.

In $2011,14.9 \%$ of U.S. households, or 17.9 million families, were food insecure at some point during the year. The majority of food insecure households were able to avoid substantial reductions in food intake but in many cases households relied on a limited variety of foods and often compromised their food choices. Still, 6.8 million households were classified as having very low food security, meaning that in those households, there were multiple incidences of disturbed eating patterns and reduced food intake. Children were food insecure in $10 \%$ of all households with children, equating to nearly 4 million households (Coleman-Jensen, Nord, Andrews, \& Carlson, 2012).

Over the previous decade, food insecurity in the United States increased from $10 \%$ in 2000 to nearly $12 \%$ in 2004 , with a slight stabilization until 2007 , followed by a significant increase in 2008 to about 14\% (Figure 2-2) (Coleman- 
Jensen, Nord, Andrews, \& Carlson, 2012). Given the dramatic effects of the economic recession, it is expected that more households, from all socioeconomic and demographic groups, may fall below the threshold of food security. And while the total percentage of food insecure households has increased in the past ten years, there have been disparate increases among different socioeconomic and demographic groups.

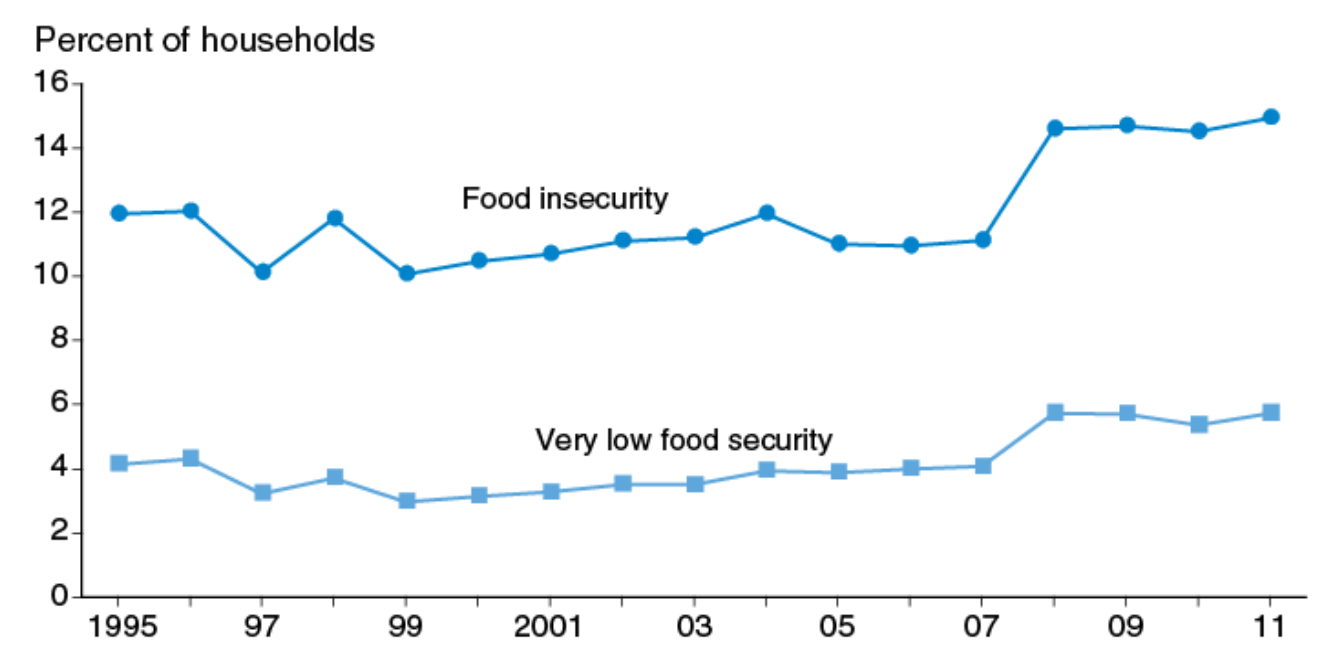

Figure 2-2: Trends in the prevalence of food insecurity and very low food security in U.S. households, 1995-2011. Figure from (Coleman-Jensen, Nord, Andrews, \& Carlson, 2012)

The prevalence of food insecurity varies considerably from state to state. In combined data from 2009-2011, the prevalence of food insecurity in California was significantly higher than the national average (Coleman-Jensen, Nord, Andrews, \& Carlson, 2012). California was one of the states hit hardest by the economic recession. From 2007 to 2009, the rate of poverty in California rose faster than the national levels (Bohn, 2011) and unemployment increased in every County in the state. In 2009 , unemployment was as high as $28 \%$ in some 
counties, with increases in unemployment as great as 10 percentage points higher from 2007 in other counties (USDA, 2011). In 2009, 40\% of low-income adults (defined as at or below 200\% Federal Poverty Level) in California were food insecure, five percentage points higher than in 2007 (Chaparro, Langellier, Birnbach, Sharp \& Harrison, 2012). Policy makers speculate that without the American Recovery and Reinvestment Act of 2009 (ARRA), Californians would have fallen even deeper into poverty and food insecurity (Chaparro, Langellier, Birnbach, Sharp \& Harrison, 2012).

San Luis Obispo County is a rural County on the central coast of California that had one of the lower rates of food insecurity in the state in 2009. However, $23 \%$, or 11,000 families of low-income households were food insecure and $7 \%$, or 3,000 families had very low food security (Table 2-4) (Chaparro, Langellier, Birnbach, Sharp \& Harrison, 2012). The median household income of the County is relatively high, yet $12 \%$ of the population lives below the poverty level (United States Census Bureau, 2012a), with higher concentrations in several critical need communities. Countywide, the population according to census data is $21 \%$ Hispanic/Latino (United States Census Bureau, 2012a); however several communities have disproportionally higher rates of low income Latino families.

San Luis Obispo is an agriculturally rich area where farmers in the County are estimated to produce enough fruits and vegetables for each County resident to receive 7.5 pounds of nutritious food a day (Cuddy, 2012), yet the number of people who cannot get enough to eat is increasing. The Food Bank Coalition of 
San Luis Obispo has seen a $90 \%$ increase in the number of people who accessed their services over the past five years (Cuddy, 2012).

Housing prices and the cost of living in the County may further intensify disparities in food security among residents. San Luis Obispo County has one of the most unaffordable housing markets in the nation (National Association of Home Builders, 2012). Percentage of spending on "housing" is already the highest among major spending components in US households and is even higher in California (Figure 2-3). Renters especially carry the burden of an overpriced housing market. Of occupied housing units in San Luis Obispo County in 2010, $59.7 \%$ were owner occupied and $40.3 \%$ were renter occupied. A higher proportion of renters in San Luis Obispo County spent more than 35\% of their household income on rent between 2007 and 2011 than did residents from the entire state, $52 \%$ and $46 \%$ respectively (The United States Census Bureau, 2012a). High housing costs force residents to spend an even greater percentage of their income on housing and are then left with fewer financial resources to pay for other necessities, such as transportation and food. 
Table 2-4: Prevalence of food insecurity (low and very low) among low-income households in California 2007 and 2009, by County in ranking order (Chaparro, Langellier, Birnbach, Sharp \& Harrison, 2012).

\begin{tabular}{|c|c|c|c|c|c|c|c|c|c|}
\hline & \multirow[b]{2}{*}{ County } & \multicolumn{2}{|c|}{$\begin{array}{c}2009 \\
\text { Food } \\
\text { Insecurity }\end{array}$} & \multicolumn{2}{|c|}{$\begin{array}{c}2007 \\
\text { Food } \\
\text { Insecurity }\end{array}$} & \multicolumn{2}{|c|}{$\begin{array}{l}2009 \\
\text { Very low } \\
\text { Food } \\
\text { Security }\end{array}$} & \multicolumn{2}{|c|}{$\begin{array}{l}2007 \\
\text { Very Low } \\
\text { Food } \\
\text { Security }\end{array}$} \\
\hline & & $\%$ & $\begin{array}{l}\text { Est. } \\
\text { Pop. }\end{array}$ & $\%$ & $\begin{array}{l}\text { Est. } \\
\text { Pop. }\end{array}$ & $\%$ & $\begin{array}{l}\text { Est. } \\
\text { Pop. }\end{array}$ & $\%$ & $\begin{array}{l}\text { Est. } \\
\text { Pop. }\end{array}$ \\
\hline \multirow{5}{*}{$\begin{array}{l}\text { Most } \\
\text { Food } \\
\text { Insecure }\end{array}$} & Contra Costa & 57.8 & 96,000 & 16.1 & 25,000 & 24.5 & 41,000 & 5.9 & 9,000 \\
\hline & Orange & 52.4 & 379,000 & 33.7 & 211,000 & 18.3 & 132,000 & 11.9 & 74,000 \\
\hline & Napa & 52.2 & 13,000 & 37.2 & 7,000 & 28.5 & 7,000 & 15.2 & 3,000 \\
\hline & Sonoma & 50.5 & 51,000 & 24.8 & 17,000 & 22.4 & 23,000 & 10.3 & 7,000 \\
\hline & Alameda & 49.1 & 169,000 & 33.8 & 95,000 & 14.9 & 51,000 & 14.3 & 40,000 \\
\hline \multirow{5}{*}{$\begin{array}{l}\text { Least } \\
\text { Food } \\
\text { Insecure }\end{array}$} & Placer & 19.0 & 8,000 & 41.3 & 13,000 & 3.4 & 1,000 & 12.0 & 4,000 \\
\hline & Humboldt, Del Norte & 20.5 & 9,000 & 28.0 & 10,000 & 8.7 & 4,000 & 16.8 & 6,000 \\
\hline & Siskiyou, Lassen, Trinity, Modoc & 20.8 & 6,000 & 33.1 & 10,000 & 8.2 & 2,000 & 25.4 & 7,000 \\
\hline & San Luis Obispo & 23.0 & 11,000 & 28.6 & 15,000 & 7.0 & 3,000 & 18.0 & 9,000 \\
\hline & Tehama, Glenn, Colusa & 28.4 & 12,000 & 40.1 & 15,000 & 10.9 & 5,000 & 17.5 & 7,000 \\
\hline
\end{tabular}

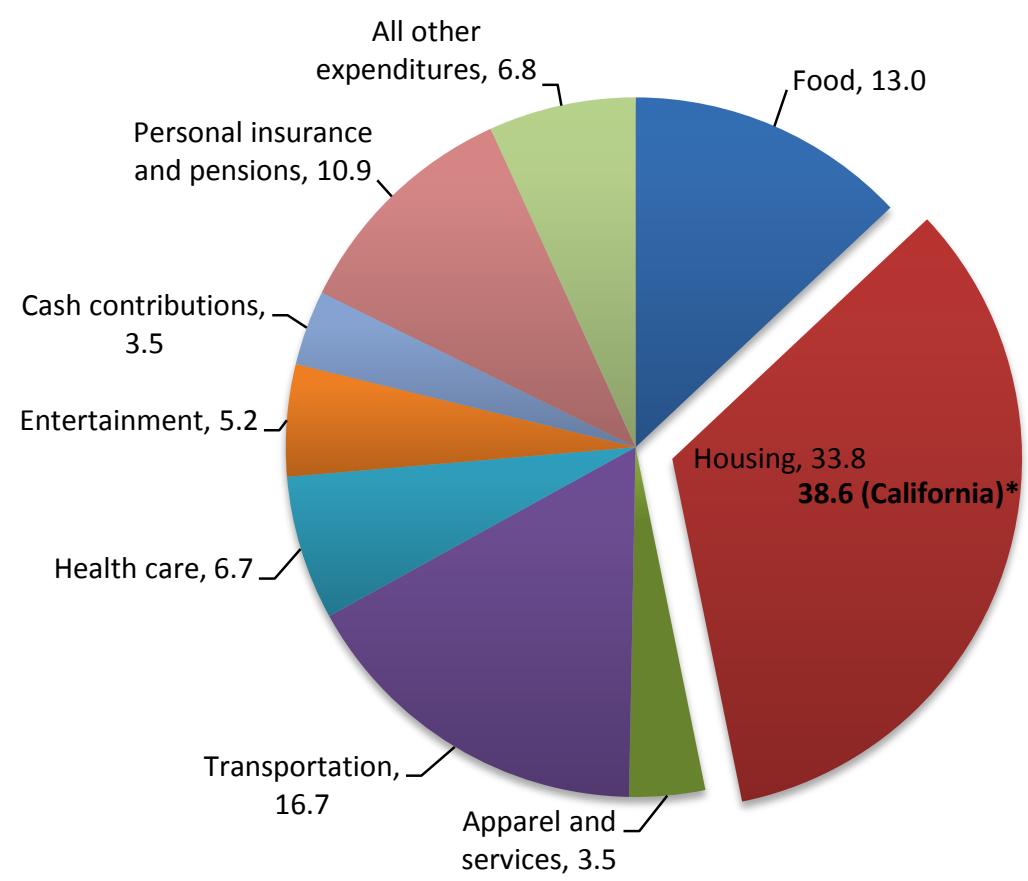

Figure 2-3: Percentages of average expenditures of major components of household spending in the U.S. in 2011 (Bureau of Labor Statistics, 2012).

*Average of San Francisco, Los Angles, and San Diego metropolitan areas 


\section{Food security disparities}

The behaviors of an individual or individuals within a household, significantly impact health. While it is clear that individuals hold responsibility for their own behaviors, there are a host of other forces that mold habits, create opportunity structures and, ultimatley affect lifestyle. The environment, physical and social, in which a person lives may constrain or expand his or her oportuntities for optimal health. An ecological framework (Figure 2-4) emphasisis these connections between people and their environement; it views behaviors and conditions as affecting and being effected by multiple levels of interacting influences (Story, Kaphingst, Robinson-O’Brien, \& Glanz, 2008). Disparities in health, as well as food security, can be more comprehensibly understood through this framework.

Sociodemographic disparities

Racial and ethnic disparities in health in the United States are substantial, with rates of heart disease, cancer and mortality much higher among racial and ethnic minorities (Williams \& Jackson, 2005). Issues of individual, structural and historical racism are the underlying cause of many of these health disparities, as well as the cause of wide gaps in food security. Socioeconomic status, whether measured by income, education or occupation, is another strong predictor of variations in health (Marmot, 2002). While ethnicity-based and class-based models are each valuable in understanding tensions in health, it is critical to examine the two together. Ethnicity and class are closely related such that 
indicators of socioeconomic status are strongly patterned by race. Ethnic differences in socioeconomic status are what contribute to ethnic differences in health and food security (Williams \& Jackson, 2005). Health and food security disparities are embedded in much larger historical, sociocultural, economic and political contexts. For the purposes of this analysis, specifically ethnicity and income will be explored in broad terms and in the framework of their associations with food security status. 


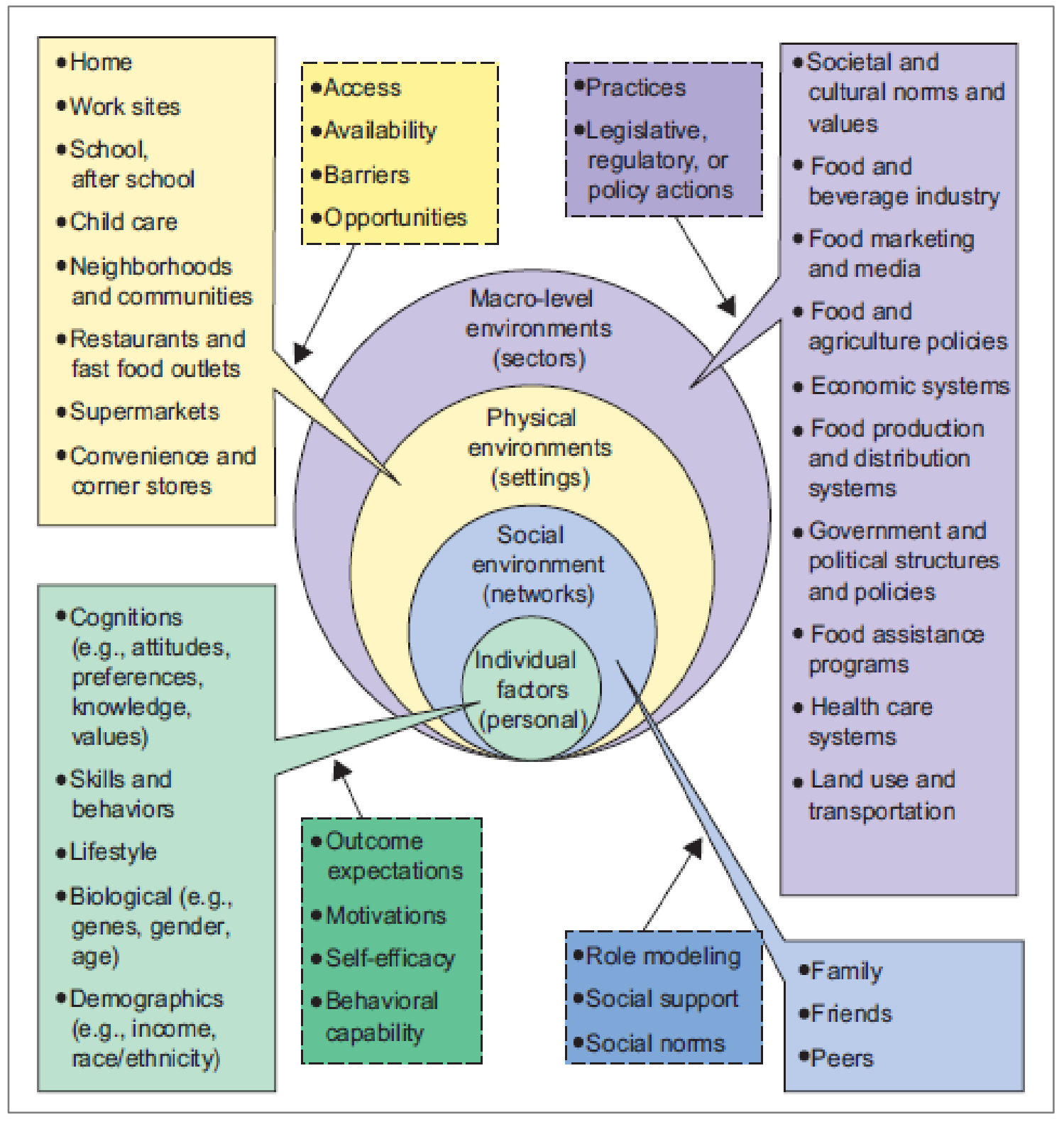

Figure 2-4: Ecological framework depicting the multiple influences on what and how people eat (Story, Kaphingst, Robinson-O'Brien, \& Glanz, 2008). 


\section{Race/Ethnicity}

The U.S. population is becoming more racially and ethnically diverse, with Hispanic/Latino populations leading in growth. More than half of the growth in the total population of the United States between 2000 and 2012 was due to the increase in the Hispanic population. As of July 2011, there were roughly 52 million Hispanic/Latinos living in the United States, representing $16.7 \%$ of the total U.S. population. By July 2050, the Hispanic/Latino population is estimated to reach 133 million, constituting more than $30 \%$ of the U.S. population by that date. California has the largest Hispanic/Latino population of any state at 14.4 million, which constitutes $27.8 \%$ of the total Hispanic population in the Country (Figure 2-5) (Ennis, Rios-Vargas, \& Albert, 2011).

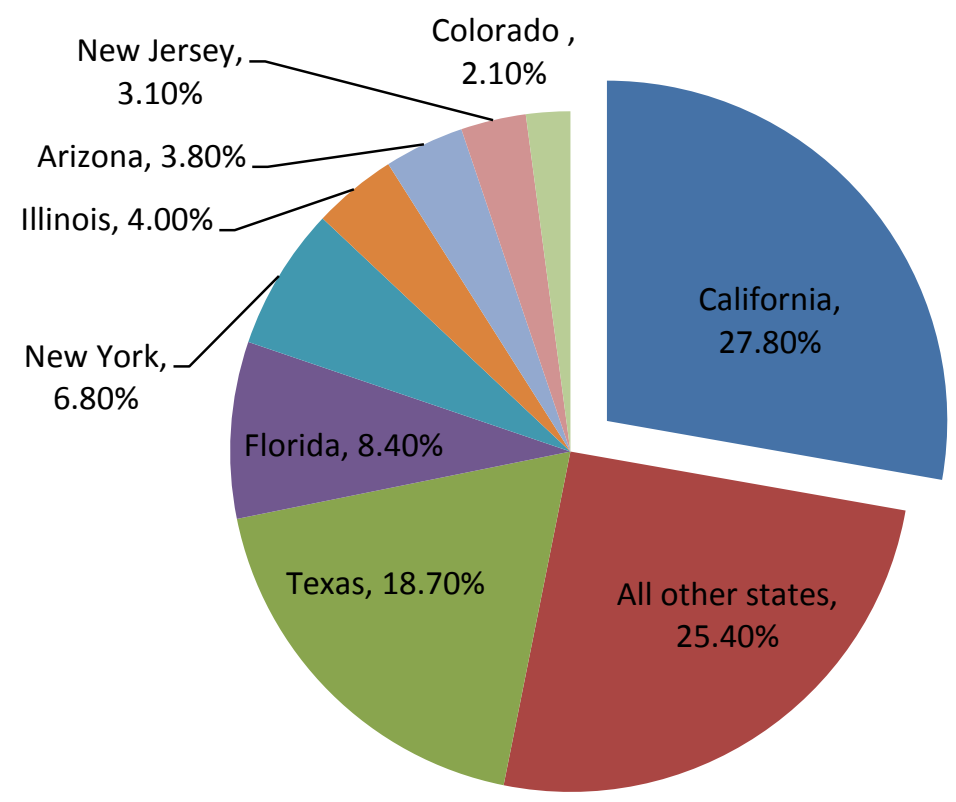

Figure 2-5: Percent distribution of the Hispanic population by state: 2010 (Ennis, RiosVargas, \& Albert, 2011). 
In 2011, more than one in four Hispanic/Latino families experienced food insecurity, the highest rate among any racial/ethnic group. Rates of food insecurity were higher in Hispanic households (26.2\%) compared to Black (25.1\%) and White non-Hispanic households (11.4\%). Hispanic/Latino families with children struggled even more, with nearly one in three households being food insecure (Coleman-Jensen, Nord, Andrews, \& Carlson, 2012). The prevalence of food insecurity was also higher among non-citizens compared to US-born and naturalized citizens, and twice as high among families whose adults did not speak English compared to English speaking families (Capp, Horowitz, Fortuny, Bronte-Tinkew, \& Zaslow, 2009). If rates of food insecurity persist at disproportionally high levels among the Hispanic/Latino population, future generations will remain at precariously elevated risk of health, economic, and social consequences.

Conclusions from investigations into elevated rates of food insecurity in Hispanic/ Latino populations are conflicting. Some studies have found that food insecurity among Latinos is attributed to the conventional factors associated with food insecurity, such as low income and low educational attainment, which are more prevalent among Latinos compared to other racial/ethnic groups. Other research has concluded that even after controlling for these socioeconomic factors, Latinos are at higher risk of food insecurity than other groups due to deeper inequalities (Mazur, Marquis, \& Jensen, 2003).

In a study that examined how low-income Latino immigrant families' met their food needs, interviews with Latino mothers revealed a variety of factors that 
affected food security status at different ecological levels (Table 2-5) (Sano, Garasky, Greder, Cook, \& Browder, 2011). The study concluded that food security involved an array of interrelated factors for each family. Interviews also suggested that even families who were in the consistently food secure group were still fearful of food insecurity and knew that food insecurity could be only a step away, be it as a result of illness or the loss of employment (Sano, Garasky, Greder, Cook, \&Browder, 2011). 
Table 2-5: Factors affecting food security status among Latino families by ecological systems levels (Sano, Garasky, Greder, Cook, \&Browder, 2011).

\begin{tabular}{|c|c|c|c|c|}
\hline & Microsystem & Mesosystem & Ecosystem & Macrosystem \\
\hline $\begin{array}{l}\text { Food } \\
\text { secure }\end{array}$ & $\begin{array}{l}\text { - Good health } \\
\text { - Many life skills } \\
\text { - Legal residency } \\
\text { - Homeownership }\end{array}$ & $\begin{array}{l}\text { - Stable employment } \\
\text { - Insurance through employer } \\
\text { - Homeownership: Family of } \\
\text { origin } \\
\text { - Extended family: Financial } \\
\text { stable } \\
\text { - Social support available from } \\
\text { friends and family (not used) }\end{array}$ & $\begin{array}{l}\text { - Local economy } \\
\text { - Community } \\
\text { atmosphere } \\
\text { - Medicaid for } \\
\text { children }\end{array}$ & $\begin{array}{l}\text { - Immigration } \\
\text { laws } \\
\text { - Public policies }\end{array}$ \\
\hline Fragile & $\begin{array}{l}\text { - Significant health } \\
\text { problem } \\
\text { - Reduced food } \\
\text { intake }\end{array}$ & $\begin{array}{l}\text { - Unstable employment } \\
\text { - Intermittent health insurance } \\
\text { - Pawn goods } \\
\text { - Borrow money from family and } \\
\text { friends } \\
\text { - Financial remittance to } \\
\text { extended family members in } \\
\text { USA or Mexico } \\
\text { - Social support from extended } \\
\text { family members for daily } \\
\text { activities, such as childcare and } \\
\text { transportation } \\
\text { - Sporadic use of public and } \\
\text { private assistance programs }\end{array}$ & $\begin{array}{l}\text { - Local economy } \\
\text { - Community } \\
\text { atmosphere } \\
\text { - Availability of } \\
\text { private } \\
\text { assistance } \\
\text { programs }\end{array}$ & $\begin{array}{l}\text { - Immigration } \\
\text { laws } \\
\text { - Public policies }\end{array}$ \\
\hline $\begin{array}{l}\text { Food } \\
\text { insecure }\end{array}$ & $\begin{array}{l}\text { - Low literacy rate } \\
\text { - Few life skills } \\
\text { - Little work } \\
\text { experience } \\
\text { - Young children in } \\
\text { the household } \\
\text { - Unexpected } \\
\text { pregnancy } \\
\text { - Occasional } \\
\text { hunger }\end{array}$ & $\begin{array}{l}\text { - Low literacy skills: Family of } \\
\text { origin } \\
\text { - Low socio-economic status: } \\
\text { Family of origin } \\
\text { - Financial remittance to } \\
\text { extended family members in } \\
\text { Mexico } \\
\text { - Many household members, } \\
\text { including extended family } \\
\text { members } \\
\text { - Limited social support from } \\
\text { family and friends } \\
\text { - Landlords who did no properly } \\
\text { maintain housing units }\end{array}$ & $\begin{array}{l}\text { - Local economy } \\
\text { - Community } \\
\text { atmosphere } \\
\text { - Lack of } \\
\text { affordable and } \\
\text { safe housing } \\
\text { - Lack of } \\
\text { enforcement of } \\
\text { housing codes }\end{array}$ & $\begin{array}{l}\text { - Immigration } \\
\text { laws } \\
\text { - Public policies } \\
\text { - Cultural } \\
\text { values against } \\
\text { receiving } \\
\text { assistance }\end{array}$ \\
\hline
\end{tabular}


Environmental and structural issues in the United States may be crippling Latino families' ability to maintain food security. For example, in neighborhoods of predominantly racial minorities, supermarkets are significantly less prevalent than in predominantly White neighborhoods (Morland, Wing, Diez Roux, \& Poole, 2002). Zip codes with predominantly Latino residents had only a third the number of chain supermarkets compared to zip codes with predominantly White residents even after controlling for differences in neighborhood income (Powell, Slater, Mirtcheva, Bao, \& Chaloupka, 2007). With fewer supermarkets, desirable and/or healthy foods may be absent and with limited availability of chain supermarkets, residents may face higher prices of food, making available food less accessible.

Limited use of government aid may be indicative of another structural barrier that compromises Latino households' food security. Supplemental nutrition programs have been shown to improve the quantity and quality of food for struggling low-income families, but there may be barriers preventing eligible Latinos from accessing the programs. Hispanic participation in SNAP is lower compared to non-Hispanic Black and White populations. Studies suggest that confusion about complex restrictions or concerns about immigration status, rather than ineligibility, may be keeping participation rates low in certain groups (Ryan, 2010). Other studies have found that lack of a permanent address due to recent homelessness or shared residence can be a barrier to Hispanic families receiving nutrition assistance, as well as limited English language skills (Algert, Reibel, \& Renvall, 2006). Undocumented immigrants are likely to make up a large population of Latinos with limited English language skills and while they are 
ineligible for SNAP, their children born in the United States are eligible to receive full benefits (Algert, Reibel, \& Renvall, 2006). Educating at-risk groups and making programs they are eligible for more accessible may mean the difference in their food security status.

Housing affordability and availability in the United States and especially in high cost of living areas such as California, compromises the ability of Latino families to meet their other household needs. Latino immigrants in small and midsized communities face an increased shortage of available housing (Quinn, 2001). In order to reduce costs, many Latino families often share housing with extended kin, increasing their household size. While a larger household may mean more total income, it usually also means more mouths to feed, which can put those families at additional risk of food insecurity (Sano, Garasky, Greder, Cook, \&Browder, 2011).

Employment may also be a factor that impacts a family's risk of food insecurity. Low-income Latino households may experience seasonal cycles of food insecurity as a result of changes in agricultural or other temporary employment (Kaiser, Melgar-Quinonez, Lamp, Johns, Harwood, \& Sutherlin, 2002). In $2004,36 \%$ of the nation's farmworkers were employed in California and nearly all were Hispanic (99\%). Of Hispanic farmworkers employed in California, $61 \%$ had seasonal employment, $20 \%$ were employed year round and $19 \%$ did not know whether their current job was year-round or seasonal (Aguirre International, 2005). In a California study of Mexican-American households during the winter, food insecurity was significantly associated with higher intakes 
among children of beans and tortillas but with lower intakes of milk, cooked vegetables, pizza and cookies. These households may have been able to afford bulk supplies, such as beans and tortillas, in the summer and save them for winter consumption but were unable to afford as many fresh foods or other snack or convenience foods, such as vegetables and cookies in unemployed months (Kaiser, Melgar-Quinonez, Lamp, Johns, Harwood, \& Sutherlin, 2002). In a crosssectional study of low-income Latino households in six California counties, researchers suspected that the relatively higher rates of food insecurity among low-income Latinos could have been due to data collection being conducted in the winter months (Kaiser, Melgar-Quinonez, Townsend, Nicholson, Fuji, Martin, \& Lamp, 2003).

\section{Income}

Income is the most influential determinant of household food insecurity because of its direct effect on ability to purchase food. Evidence from the 2011 Current Population Survey (CPS) showed that $41 \%$ of households with incomes $<185 \%$ of the Federal Poverty Limit (FPL) were food insecure, whereas only $7 \%$ of households with incomes $>185 \%$ FPL were food insecure (Coleman-Jensen, Nord, Andrews, \& Carlson, 2012). Even after controlling for other confounding variables such as ethnicity, education, region of the Country and household composition, those living in poverty were still more than 3.5 times as likely to be food insufficient than those living above the poverty threshold demonstrating the importance of income (Rose, 1999). Moreover, food security is related to income in a dose-response fashion, whereby individuals who were food secure had a 
higher income than those mildly and moderately insecure and the mildly insecure had a higher income than the moderately insecure (Townsend, Peerson, Love, Achterberg, \& Murphy, 2001).

In 2011, the average U.S. household spent $\$ 47.50$ per person per week on food (Coleman-Jensen, Nord, Andrews, \& Carlson, 2012). Households with higher incomes spent a higher percentage of their income on food than did lower income households. Households with incomes below the poverty limit spent about $7 \%$ less than the cost of the Thrifty Food Plan (a USDA designated food plan which specifies foods and amounts of foods to provide adequate nutrition), whereas households above $185 \%$ FPL spent $26 \%$ more than the Thrifty Food Plan. Other groups that spent less on food, as compared to their counterparts included households with children under 18 years old, households headed by single women, and Black non-Hispanic and Hispanic households. These patterns are consistent with lower average rates of income and higher prevalence rates of food insecurity among these groups (Coleman-Jensen, Nord, Andrews, \& Carlson, 2012). Changes in income also modify the types of foods that are purchased (Drewnowski \& Specter, 2004). Income largely determines how much and what types of food are accessible to a household, but research has shown that it also determines how much and what types of foods are available. In an analysis of 221 census tracts, researchers found that there were more than three times $(95 \% \mathrm{Cl} 1.4-7.9)$ as many supermarkets in wealthier neighborhoods compared to the lowest-wealth areas. Fast-food restaurants and bars and taverns also became more prevalent as wealth decreased (Morland, Wing, Diez 
Roux, \& Poole, 2002). Lower socioeconomic status groups were also less likely to have private vehicles for use for food shopping which can make the location of food stores even more crucial to these groups (Turrell, 1996). Thus, households living in poverty tend to have less income to spend on food and also have fewer food options available to them.

It is important to recognize that the national poverty guidelines are one dimensional and do not capture the true condition of poverty. The federal poverty limit does not take into account price differences in food, housing or employment status, nor does it respond to nuanced family situations such as being a single parent or living with additional family members. The poor are typically the most vulnerable but there are factors that contribute to vulnerability beyond income. A greater examination of other household characteristics would further determine increased risk of food insecurity as well as coping capacities and the outcome of inability to attain food for a family. Understanding these characteristics may be critical for policy makers and public health professionals to better plan strategies to more completely address food insecurity.

\section{Household composition disparities}

According to life history theory, decisions about how to invest energy and resources are made at the molecular, physiological and behavioral level. Hill (1993) explains that total energy available to an individual is finite and can only be selectively spent. With limited energy and resources available, tradeoff strategies must be considered when examining household composition. Embracing this model, it is apparent how allocation patterns of an individual or 
household can affect offspring, marital status and employment. Each of these characteristics of household composition is modified by conscious or subconscious energy investments and each subsequently influences long-term health and food security.

\section{Children}

Having children puts households at increased risk for food insecurity. Food insecurity was more prevalent in households with children (20.6\%) than in households without children (12.2\%). Households with children under 6 years were even more likely to be food insecure (21.9\%). Among all households with children, $10.6 \%$ of households had only adults who were food insecure but in the other 10\% (3.9 million households), both children and adults were food insecure at some point during the year (Coleman-Jensen, Nord, Andrews, \& Carlson, 2012). Additionally, food insecurity among children was more than twice as prevalent in households headed by Black and Hispanic persons as those headed by White non-Hispanic persons (Nord, 2009). Hispanic women also tend to have more children, based on total fertility rates (United States Census Bureau, 2010), and are therefore at additional risk of food insecurity. Food insecurity was also more prevalent in larger families, especially in those with three or more children (Nord, 2009). Therefore, children represent an important economic investment for parents.

Parental investment, which contributes to food security status, includes transfers of items requiring production (food) and direct caregiving (time) (Hofferth \& Anderson, 2003). Acknowledgement of quality-quantity tradeoffs in 
parental investment, whereby parents face a decision between having fewer "high-quality" versus more "low-quality" offspring, may clarify economic decisions that leave households with more children more food insecure. Dependent on available resources, optimal investment per offspring will differ. As life history and parental investment theory predict, in environments where parents have unprecedented access to food and resources they are likely to have fewer children and invest more resources in them, whereas in deprived situations the opposite pattern is true (Hill \& Kaplan, 1999).

There may also be a distinct difference in the nature of food-related hardship in food insecure households with or without children. An analysis of specific questions from the HFSSM found that households with children were much more likely to answer affirmatively to being "worried food would run out" (22.2\%), as opposed to households without children (11.3\%). Households with children also more often answered affirmatively to the question asking about "balanced meals" (12.5\%) compared with only $8.5 \%$ of households without children. Holding constant the approximate level of food security, it appears that the manifestations of struggle are qualitatively different among different types of households and that households with children may react differently to food insecurity (Wilde, 2004). These differences are important to consider in understanding diverse types of households, and how household composition may change the outcomes of a condition. 


\section{Marital status}

In 2011 , rates of food insecurity were below the national average of $14.9 \%$ for married-couple families with children (13.9\%), whereas rates for households headed by single women or single men with children were much higher than the national average (35\% and 25\%, respectively) (Coleman-Jensen, Nord, Andrews, \& Carlson, 2012). Single-parent households may have extra expenses due to child care and lower income than households with two parents, which could contribute to their higher rates of food insecurity and poverty. Female-headed households with children under 18 were four times more likely to live in poverty in 2011 as opposed to households with a married couple (United States Census Bureau, 2012b). Additionally, studies have shown that families headed by a single parent allocate their food budgets differently than do married-couple families and are likely to spend a smaller proportion of their food budget on fruits and vegetables and a greater proportion on alcohol (Ziol-Guest, DeLeire, \& Kalil, 2006). Consequently, the limited income that single parents do have to allocate towards food for their family may be further diminished by personal food or beverage choices.

Economic consequences could be expected to deter adults from opting into a single-parent situation; however, rates of single-parent households continue to rise in the US. The percentage of single-parent households in the United States has been growing since the 1960's and increased from $27.0 \%$ in 2000 to $29.5 \%$ in 2008 (United States Census Bureau, 2012c). Causes of this shift are unknown but have been attributed to the economic independence of 
women, the decline in men's earning power relative to women's, and shifts in social norms and values (McLanahan, 2001). Regardless of the causes, it is important to recognize single-parents as a growing population who disproportionality suffers from economic problems and food insecurity. There may also be important differences within single- or married-parent families when considering the employment status of all parents(Ziol-Guest, DeLeire, \& Kalil, 2006), which may ultimately determine income, further putting single parents at risk for food insecurity.

\section{Employment}

Work (paid employment outside of the house) influences health behaviors such as food choices and dietary practices, as well as energy expenditures and requirements (Popkin, Duffey, \& Gordon-Larsen, 2005). Employment also affects income, which is directly associated with food security. An analysis of data from a longitudinal study on the well-being of children and families in the wake of welfare reform, found that as mothers move into employment, rates of food insecurity and financial strain decline. The researchers warned that these links may not prove directionality or causality and that women's psychological wellbeing, employment and welfare status may be particularity endogenous, meaning that it may be difficult to tease apart the individual impacts of these highly correlated variables. Other findings from the study showed that mothers who moved into employment reported feeling better about themselves and showed significant increases in self-esteem and decline in indicators of depression. These changes in psychological well-being may further convolute the relationship 
between employment and food security (Coley, Lohman, Votruba-Drzal, Pittman, \& Chase-Lansdale, 2007). While employment per se may impact food security, other conditions associated with employment may also have an independent influence on household food security.

Employment is only one measure of economic stability, and may be too superficial to represent overall financial condition. Another study of single mothers sampled from welfare offices found that child development effects stemming from poverty were the result of more proximal factors that were related to phenomena such as maternal mental health and support networks. These proximal determinants were found to be shaped more consistently by long-term economic security rather than short-term employment, demonstrating the relatively lesser impact of employment per se. Even when selecting women who had worked during the past year, food security status remained robust in determining proximal determinants. There was a similar pattern among mothers with higher quality jobs (those with at least health benefits). These findings underscore the importance of addressing income and broader issues of economic security, as opposed to strictly unemployment status (Fuller, Caspary, Kagan, Gauthier, Haung, Carroll, \& McCarthy, 2002). Rose (1999) also stresses that indirect measures of well-being, such as income or employment status, are not sensitive to the hunger condition and may therefore fail to recognize food insecurity as a dynamic situation. He has looked more specifically at the role of an explicit event, such as job loss, that then puts additional stress on a household, tipping a borderline family into food insecurity. 
It is important to recognize the group of working poor families within food insecure families, who are often overlooked due to common misconceptions about hunger. In 2010, 10.5 million people were among the working poor, meaning that they had spent at least 27 weeks in the labor force but still had incomes that fell below the national poverty level. Those at higher risk of being among the working poor include part-time workers, Blacks and Hispanics, and female headed households. Additionally, among families with at least one member in the labor force, those with children were four times more likely than those without children to live in poverty (United States Census Bureau, 2012d). These individuals are at particular risk of food insecurity because although they are earning an income, they may nonetheless have to choose between paying for housing, medical expenses, or food (Nazmi \& Lund, 2012). Compounding the problem, they may not qualify for some supplemental nutrition programs. This is evidenced by the fact that in California the percentage of food insecure individuals who reported being employed increased from $28.4 \%$ in 2001 to $42.6 \%$ in 2012 (Chaparro, Langellier, Birnbach, Sharp \& Harrison, 2012).

Rates of food security follow rates of employment, which parallel the nation's economic status such that when the economy is in an expansionary phase and unemployment is low or declining, food insecurity tends to also decline (Cook, 2002). Through an analysis of historic economic periods in the United States, Cook suggests that the "full employment" unemployment rate (i.e. the lowest unemployment rate that the U.S. could ever reach and possibly sustain) is not lower than four percent. This means that unemployment is unlikely 
to fall below four percent and that poverty and food insecurity are unlikely to ever completely resolve, even during major economic booms (Cook, 2002). 


\section{CHAPTER 3: METHODS}

\section{Hunger-Free Communities Project}

In 2010, The Food Bank Coalition of San Luis Obispo County was awarded an 18-month planning and assessment grant from the USDA in the value of $\$ 99,561$, one of only 14 nationwide. This award was part of the HungerFree Communities section of the 2008 Food, Conservation and Energy Act (a.k.a. 2008 Farm Bill), which appropriated $\$ 5$ million in grant funding for the USDA to provide public funding to end hunger at the community level (USDA, 2012a).

The objective of the Hunger-Free Communities (HFC) project was to identify the extent and causes of hunger in San Luis Obispo County, including assessing household food security, determining accessibility of food resources, identifying low availability and high cost food areas, assessing community food production resources and identifying other barriers to food security (USDA, 2012a). The Food Bank Coalition partnered with other nutrition, agriculture and environmental organizations in San Luis Obispo in order to fulfill these objectives. The STRIDE (Science through Translational Research in Diet and Exercise) Program at California Polytechnic State University, San Luis Obispo was engaged to conduct household-level food security assessments. The STRIDE team included STIRDE staff, students involved with the Program and community partners. 
Food security assessment survey development

A primary objective of the HFC project was to sample vulnerable groups who had been historically under-represented in similar studies, and to better understand food insecure populations, rather than to measure food security status of the County as a whole. To define the vulnerable population, more than 50 community agencies that provide services to at-risk groups were consulted. These agencies approximated characteristics and numbers of the counties vulnerable populations. The following populations were identified as vulnerable: working poor/low-income families, low-income seniors, farm workers, physically or mentally disabled, veterans, homeless, and single women/mothers. Most agencies agreed that their clients were generally $60 \%$ English speaking and $40 \%$ Spanish speaking; and all agencies agreed that there had been an increased need for service in their specific population over the last five years.

A custom food security assessment survey was developed to characterize factors associated with household food insecurity among the identified vulnerable populations in the County (Appendix A). The food security assessment survey was designed to reflect food security at the household level among vulnerable populations and to capture characteristics specific to groups that may be at risk of food insecurity. Questions in the survey were separated into three parts: sociodemographic information, food security assessment, and community assessment. Sociodemographic information collected included sex, age, race/ethnicity, marital status, living situation, among others, and utilized questions from previously standardized and validated surveys, including an 
established acculturation scale (Hazuda, 1988). The USDA 6-item HFSSM (Table 2-2) was used in the food security assessment portion of the survey, along with questions from the USDA Adult Food Security Module (USDA, 2012b) and the Food Security Supplement from the Current Population Survey (USDA, 2009). The community assessment portion of the survey asked an open ended question with regard to how the interviewee thought that the community could reduce hunger. The entire survey, as well as the written informed consent form, was translated into Spanish (Appendix B) for the purpose of administering the survey to non-English speakers or persons who felt more comfortable answering the questions in Spanish. The survey was translated and back translated by native Spanish speaking staff members of the Food Bank Coalition to ensure clarity and meaning.

Following initial development of the food security assessment survey instrument, key informant interviews were conducted with members of partner community agencies. Interviews allowed for specialists in the community to give feedback on survey content and verbiage so the survey could be understood by all target populations and address their potential issues in an appropriate manner. These interviews and other discussions with community partners also helped to determine the interview site locations (Table 3-1) and geographic breakdown of where surveys would be conducted throughout the County. Public places such as parks, churches and laundromats were also included in survey sites to capture vulnerable populations that may otherwise not have been 
represented in the sampling estimates of established agencies and

organizations.

Table 3-1: Food security assessment survey sites and number of visits

\begin{tabular}{|c|c|c|c|}
\hline Site, Location: & $\begin{array}{l}\# \\
\text { visits }\end{array}$ & Site, Location: & $\begin{array}{l}\# \\
\text { visits }\end{array}$ \\
\hline Anderson Hotel, San Luis Obispo & 2 & Nipomo Health Fair, Nipomo & 1 \\
\hline CapSLO site, San Luis Obispo & 1 & Noor Clinic, San Luis Obispo & 1 \\
\hline Central Market, Oceano & 1 & Market, Shandon & 1 \\
\hline Coin-Op Laundromat, Cambria & 1 & Oak Park Recreation, Paso Robles & 1 \\
\hline Community Center, Los Osos & 1 & Oceano Dunes, Oceano & 1 \\
\hline Community Center, San Miguel & 1 & Oceano Elementary School, Oceano & 1 \\
\hline Cookie Crock Grocery, Arroyo Grande & 1 & Oceano Family Resource Center, Oceano & 1 \\
\hline D. Sinton's Farm, Creston & 1 & Oceano Senior Center, Oceano & 2 \\
\hline Del Mar Elementary School, Morro Bay & 1 & Pacheco Elementary School, San Luis Obispo & 1 \\
\hline Family Resource Center, Paso Robles & 1 & People Self-Help Housing, Los Osos & 1 \\
\hline Grace Church, Paso Robles & 1 & Prado Day Center, San Luis Obispo & 2 \\
\hline Grace Church, San Luis Obispo & 1 & Redemption Center, San Luis Obispo & 1 \\
\hline Grande Hall, Atascadero & 1 & Salvation Army, Morro Bay & 1 \\
\hline Health Fair, Arroyo Grande & 1 & Santa Rosa Elementary School, Atascadero & 1 \\
\hline Heritage Ranch, Paso Robles & 1 & Senior Center, San Luis Obispo & 1 \\
\hline Home Visits by Belen, County wide & 1 & Senior Center, Santa Margarita & 1 \\
\hline Junior High School, Atascadero & 1 & Shouts of Grace Church, Grover Beach & 1 \\
\hline La Mexicana Market, Los Osos & 1 & Soto Park, Arroyo Grande & 2 \\
\hline Laundromat, San Luis Obispo & 1 & St. Joseph's Catholic Church, Nipomo & 2 \\
\hline Laundromat, Grover Beach & 1 & St. Patrick's Church, Arroyo Grande & 1 \\
\hline Laundromat, Oceano & 1 & Transitions Facilities, San Luis Obispo & 1 \\
\hline Laundromat, Shandon & 1 & United Methodist Church, Shandon & 1 \\
\hline Lillian Larson, San Miguel & 1 & Veterans Hall, Morro Bay & 3 \\
\hline Loaves \& Fishes, Paso Robles & 1 & Villa Paseo Apartments, Paso Robles & 1 \\
\hline Mercy Church, San Luis Obispo & 1 & Vineyard Church, San Luis Obispo & 1 \\
\hline Mission View Health Center, San Luis Obispo & 1 & Virginia Peterson Elementary School, Paso Robles & 1 \\
\hline Mitchell Park, San Luis Obispo & 1 & WIC Office, County wide & 1 \\
\hline
\end{tabular}

Survey training and administration

Administration of the food security assessment surveys at determined

sites (Table 3-1) was conducted by 98 trained research assistants, including 
students from California Polytechnic State University, San Luis Obispo Kinesiology, Nutrition and Spanish departments, as well as community volunteers and members of partner agencies. A comprehensive training manual (Appendix D) was developed to instruct interviewers on standardized survey methods. The training manual covered general interviewing techniques (e.g. nonverbal cues, interpreting responses) and specific instructions on individual questions (e.g. responses may be entered in years or month depending on interviewee response). All interviewers completed a two-day training in which they read the manual, clarified concerns with lead researchers and piloted the survey among other trainees. Spanish-speaking interviewers were trained in English but piloted the survey in Spanish with other Spanish speakers. In specific cases where it was unsuitable to bring unfamiliar people to a site to conduct surveys, an established contact within the agency was trained individually by one of the lead researchers. The contact then conducted an assigned number of surveys at their site and the completed surveys were picked up at the end of the month. For example, at remote farm sites, which primarily employ undocumented workers, it was more appropriate to train an established and trusted contact who worked directly with the farm workers to administer the surveys.

Food security assessment surveys were conducted by groups of research assistants at designated sites, or by trained members of partner agencies at their own sites, between October and November of 2011. Groups of students and volunteers were overseen by at least one lead researcher, who served as the 
point person for visited agencies staff and for the interviewers. The lead researcher also logged and collected all completed surveys at a given site.

Depending on the nature of the site, the lead researcher established a plan for the interviewers; for example, at a food pantry distribution site, the interviewers were to approach people in line and invite them to take the survey while they were waiting. At some church sites, participants were offered coffee and snacks if they would be willing to sit with an interviewer and complete the survey. The survey was voluntary, and the majority of people approached complied with participation and many were excited to hear about the project and happy to share their stories with the research assistant.

\section{Data cleaning and analysis}

Food security assessment data was collected on paper surveys by individual interviewers. Each survey was coded to ensure an organized filing system and the hardcopy of each survey was kept as a reference. Custom electronic databases were created using Microsoft Access to input data from paper surveys. All surveys underwent double data entry and comparison for quality control by research assistants and STRIDE staff. Entered data was coded based on a numerical scheme designed by the lead researchers and the STRIDE data base team. Primary data cleaning involved cross comparisons between duplicate entries to capture potential errors in data entry. Secondary cleaning included removing implausible data and the recoding of variables. Several continuous variables were categorized into groups. For example, the number of children in a household was collected as an ordinal variable, and for this 
analysis, children were grouped into categorical ranges. New variables were also created from collected data. For example, per capita monthly income was calculated from reported total monthly income and total number of household members. Appendix E shows all modified variables used in this analysis.

The outcome variable of interest in this analysis was the presence of food insecurity (dichotomous), defined by the USDA 6-item HFSSM. The USDA designates "low food security" and "very low food security" classifications (Nord, 2012); however, for the logistic regression models of this analysis the two classifications were combined to reflect a single "food insecurity" variable. In other descriptive data the variable is presented in the three classifications: food secure, low food security and very low food security. Three household characteristics were investigated as independent variables: marital status, number of children in the household and number of workers in the household. Some of these variables were modified or created for the purpose of this analysis (Appendix E).

Descriptive analysis was conducted for each section of the survey, for the overall sample and by race/ethnicity (Hispanic/Latino and White). Bivariate analyses included chi-squared tests (Pearson's and chi-squared tests for trend) and Analysis of Variance (ANOVA) tests. A wide range of literature on the racial/ethnic differences of the determinants of food security suggests that models should be stratified, and interaction analyses confirmed this. Sequentially adjusted logistic regression models were created to test the association between each of the descriptive variables and the outcome variable while controlling for 
potentially confounding and mediating variables. Statistical analysis was conducted using Stat/IC 10 (College Station, USA).

A hierarchical conceptual framework was constructed to contextualize associations between variables and to guide statistical analyses (Figure 3-2). Variables range from most proximal, to most distal in their determination of the outcome (food security status). Those variables higher up in the framework affect, directly or indirectly, other variables below them and most likely work through a number of inter-related proximate determinants (Victora, Huttly, Fuchs \& Olinto, 1997). The hierarchical nature of this model lends itself to a consecutive series of causal effects; however, those pathways are not necessarily ordered or linear.

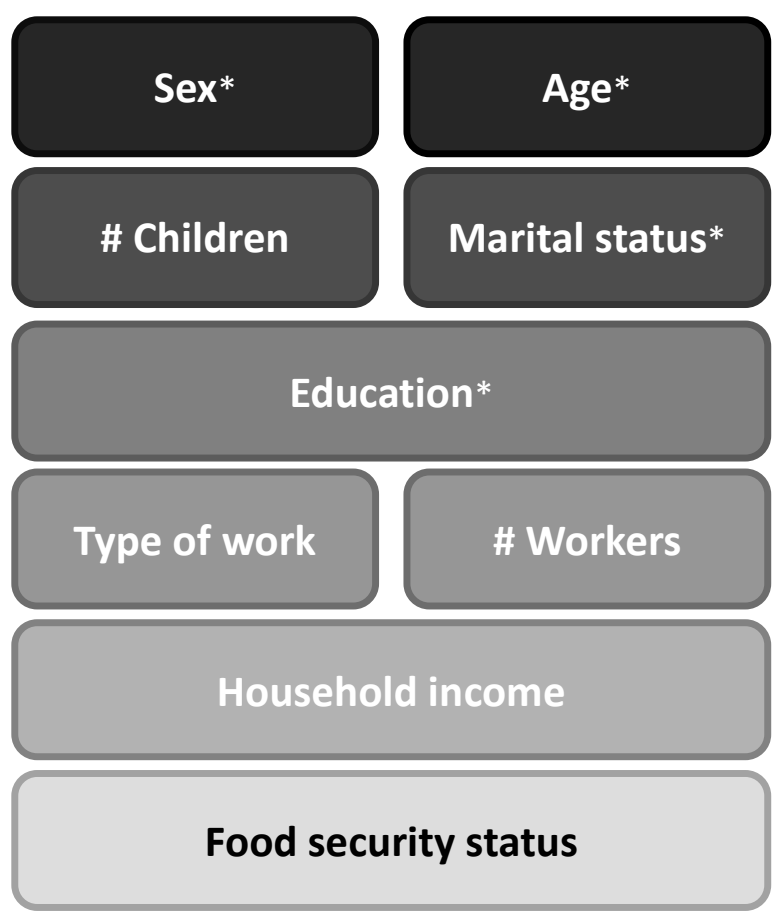

Figure 3-1: Hierarchical conceptual framework for the relationship between examined variables and food security

*Individual level data used to represent the household 
The California Polytechnic State University Institutional Review Board approved all aspects and phases of the study. Participants provided written informed consent (Appendix C). Consent forms were included with each survey in the appropriate language; one to be signed by the interviewee and kept on record with the completed survey, and one for the interviewee to keep with University contact information included. 


\section{CHAPTER 4: RESULTS}

\section{Sociodemographic characteristics}

A total of 808 food security assessment surveys were collected, 559 (69\%) in English and 249(31\%) in Spanish. Sociodemographic characteristics of households appear in Table 4-1. Respondents of a race/ethnicity other than Hispanic/Latino or White were excluded from this analysis ( $11 \%$ of total sample) to better examine these two specific groups. Survey respondents were primarily women (64\%), with a broad representation from all age groups. The average White respondent completed 13.2 years of school and the average Hispanic/Latino respondent completed 9.7 years $(p<0.001) .{ }^{1}$ The mean per capita monthly income of all households was $\$ 673.00$ with significant differences between Hispanic/Latino and White households $(p<0.001)$. Ninety percent of all households had incomes at or below $185 \%$ of the Federal Poverty Level (FPL), with $60 \%$ at or below $100 \%$ FPL. Most respondents were married and differences in marital status existed between Hispanic/Latino and White households ( $p$ $<0.001)$. There were also differences in number of children $(p<0.001)$, such that Hispanic/Latino households had more children than White. Similarly, Hispanic/Latino households had more workers $(p<0.001)$. Type of work also varied between the groups $(p<0.001)$. The majority of workers in Hispanic/Latino households worked full-time with no benefits, whereas a larger proportion of White households had part-time workers.

\footnotetext{
${ }^{1}$ Survey respondents answered some individual questions as representatives of their households in addition to household level questions.
} 
Table 4-1: Mean \pm SD or proportion of sociodemographic characteristics of vulnerable San Luis Obispo County households, overall and by ethnicity

\begin{tabular}{|c|c|c|c|c|}
\hline & $\begin{array}{l}\text { Overall } \\
(n=712)^{\infty}\end{array}$ & $\begin{array}{l}\text { Hispanic/Latino } \\
(n=377) \infty\end{array}$ & $\begin{array}{l}\text { White } \\
(n=335) \infty\end{array}$ & $p$-value \\
\hline $\operatorname{Sex}^{*}$ & & & & $<0.001$ \\
\hline Male & 36 & 25 & 49 & \\
\hline Female & 64 & 75 & 51 & \\
\hline Age, in years ${ }^{*}$ & & & & $<0.001$ \\
\hline $14-30$ & 18 & 23 & 12 & \\
\hline $31-40$ & 23 & 36 & 9 & \\
\hline $41-50$ & 15 & 17 & 13 & \\
\hline $51-64$ & 26 & 16 & 37 & \\
\hline 65 or older & 18 & 7 & 29 & \\
\hline Monthly income, $\$^{\mathrm{a}}$ & $1535.93 \pm 1285.31$ & $1661.16 \pm 1155.25$ & $1414.08 \pm 1391.49$ & $<0.001$ \\
\hline Per capita monthly income, $\${ }^{a}$ & $673.00 \pm 702.04$ & $501.39 \pm 556.36$ & $840.54 \pm 785.16$ & $<0.001$ \\
\hline$\leq 100 \%$ Federal Poverty Level (FPL) & 60 & 68 & 53 & $<0.001$ \\
\hline$\leq 130 \% \mathrm{FPL}$ & 77 & 82 & 71 & 0.002 \\
\hline$\leq 185 \% \mathrm{FPL}$ & 90 & 94 & 85 & 0.001 \\
\hline Years of school completed ${ }^{*}$ & $11.4 \pm 3.8$ & $9.7 \pm 3.9$ & $13.2 \pm 2.7$ & $<0.001$ \\
\hline Education level completed ${ }^{*}$ & & & & $<0.001$ \\
\hline None to elementary & 14 & 25 & 2 & \\
\hline$<$ High School & 25 & 35 & 15 & \\
\hline High School & 26 & 23 & 30 & \\
\hline Some College & 23 & 13 & 34 & \\
\hline College & 12 & 5 & 20 & \\
\hline Marital Status ${ }^{*}$ & & & & $<0.001$ \\
\hline Married/ Civil union & 48 & 67 & 27 & \\
\hline Single & 28 & 22 & 34 & \\
\hline Divorced/Separated & 17 & 9 & 25 & \\
\hline Widowed & 8 & 3 & 13 & \\
\hline Number of children in household ${ }^{b}$ & & & & $<0.001$ \\
\hline 0 & 43 & 16 & 73 & \\
\hline 1 & 11 & 13 & 10 & \\
\hline $2-3$ & 29 & 43 & 13 & \\
\hline $4-5$ & 14 & 23 & 3 & \\
\hline 6 or more & 3 & 4 & 1 & \\
\hline Number of workers in household & & & & $<0.001$ \\
\hline 0 & 39 & 16 & 63 & \\
\hline 1 & 39 & 49 & 28 & \\
\hline 2 & 17 & 25 & 7 & \\
\hline 3 or more & 6 & 10 & 1 & \\
\hline Type of employment ${ }^{c}$ & & & & $<0.001$ \\
\hline Full-time with benefits & 21 & 22 & 20 & \\
\hline Full-time without benefits & 41 & 45 & 30 & \\
\hline Part-time & 21 & 14 & 38 & \\
\hline Seasonal or temporary & 17 & 19 & 12 & \\
\hline
\end{tabular}

$\infty \mathrm{N}$ varies by analysis due to missing data

$\sim$ p-values (Hispanic/Latino vs. White) by Pearson's chi ${ }^{2}$ test or one-way ANOVA

${ }^{*}$ characteristics of survey respondent

${ }^{a}$ total combined monthly income for household from all sources

${ }^{\mathrm{b}}$ children of any age

${ }^{c}$ type of work of primary employed member of household 
Figure 4-1 illustrates the proportion of vulnerable households in each food security category, as classified by the USDA 6-item HFSSM. Throughout this analysis food security is classified either in three categories, high/marginal food security, low food security and very low food security, or as a dichotomous variable, food secure or food insecure (where low and very low food security are combined). Definitions of labels are explained in Table 2-1. Seventy four percent of the overall sample was food insecure. Differences exsisted between Hispanic/Latino and White households when examining food security in the three category convention $(p<0.001)$ but not in the dicotonous convention $(p=0.3)$. A larger proportion of food insecure White households were considered to be very low food security, as opposed to food insecure Hispanic/Latino households.

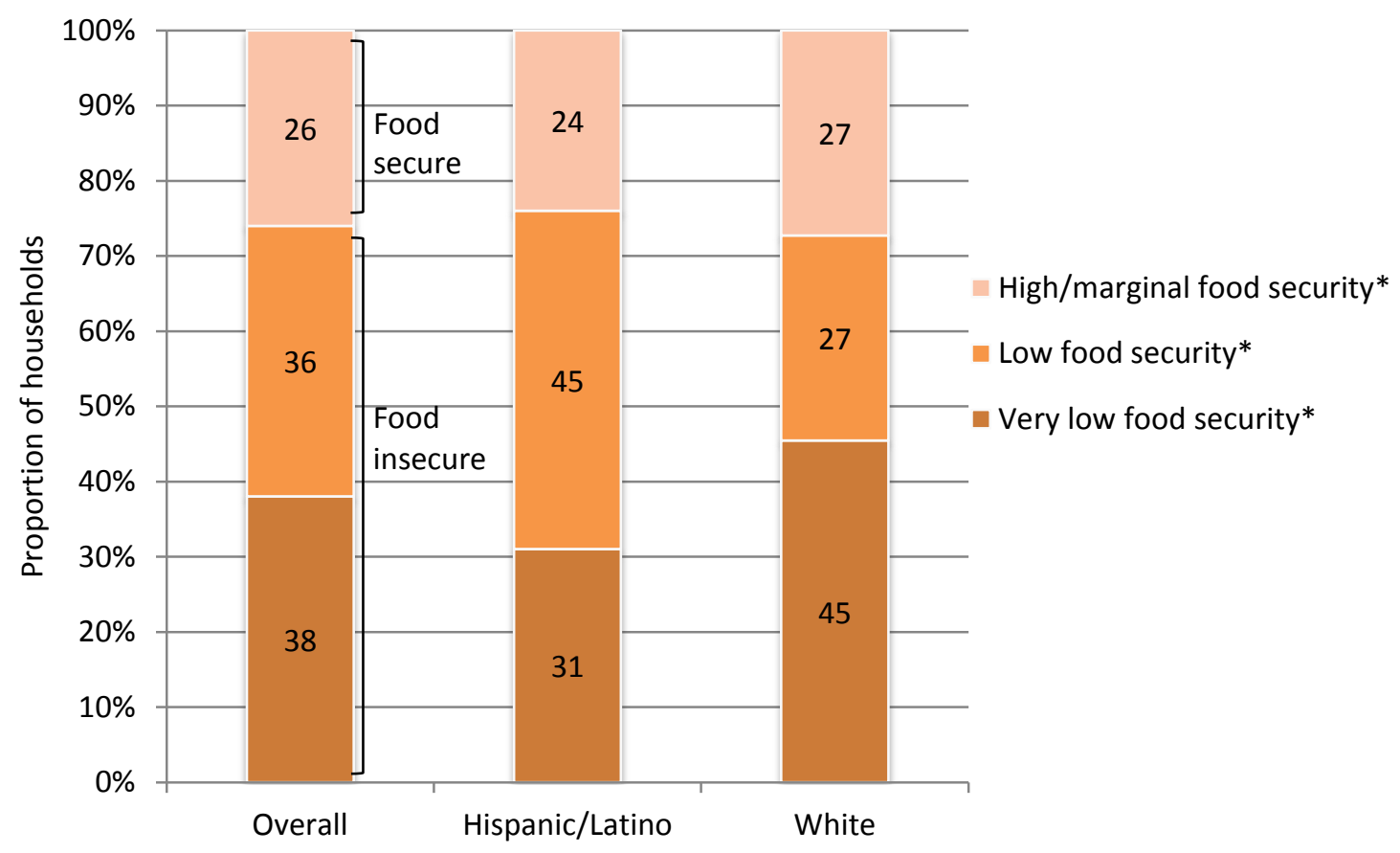

Figure 4-1: Proportion of households in each food security category, overall and by ethnicity p-value for difference between Hispanic/Latino and White $=<0.001$ as classified by the USDA 6-item HFSSM 


\section{Descriptive results}

Poverty and income

The proportion of households living in poverty, at all FPL cutoffs, varied according to marital status of the respondent in White households $(p=0.008$ for $\leq 100 \% \mathrm{FPL},<0.001$ for $\leq 130 \% \mathrm{FPL}$ and 0.001 for $\leq 185 \% \mathrm{FPL}$, only $130 \% \mathrm{FPL}$ shown). Fifty three percent of White households with respondents who were married were at or below $130 \% \mathrm{FPL}$, as opposed to $80 \%$ of households with a divorced respondent (Table 4-2). Differences between marital status and poverty were not significant in Hispanic/Latino households at any of the FPL cutoffs ( $p=$ 0.3 for $\leq 100 \% \mathrm{FPL},<0.2$ for $\leq 130 \% \mathrm{FPL}$ and 0.4 for $\leq 185 \% \mathrm{FPL})$.

Table 4-2: Proportion of households with incomes ${ }^{a}$ less than or equal to $130 \%$ of the Federal Poverty Level according to marital status, stratified by ethnicity

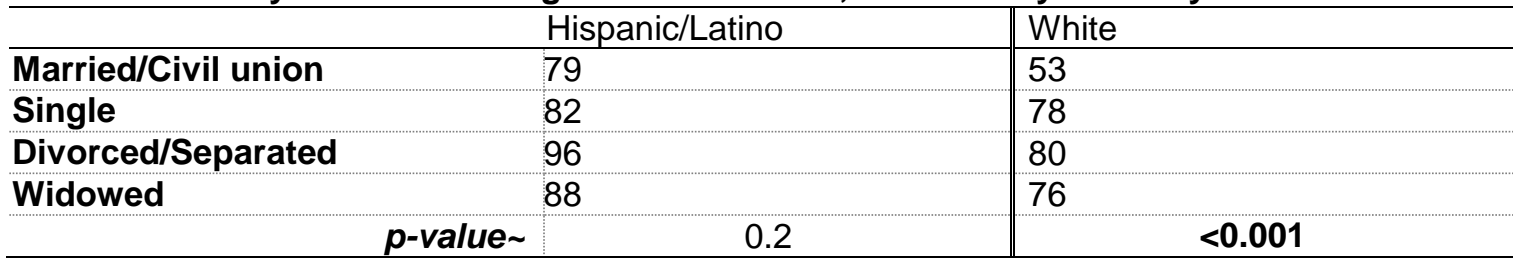

$\sim p$-values from Pearson's chi-squared tests

${ }^{a}$ total combined monthly income for household from all sources

In White households, the number of children and the household income were strongly and directly related $(p<0.001$, Chi-squared test for trend $p<0.001)$. An association was less clear in Hispanic/Latino households but there was still a strong trend within the group $(p=0.2$, Chi-squared test for trend $p<0.001)$

(Figure 4-2). Number of children was strongly associated with education in Hispanic/Latino households $(p=0.001)$, but not in White households $(p=0.9)$ (not shown). 


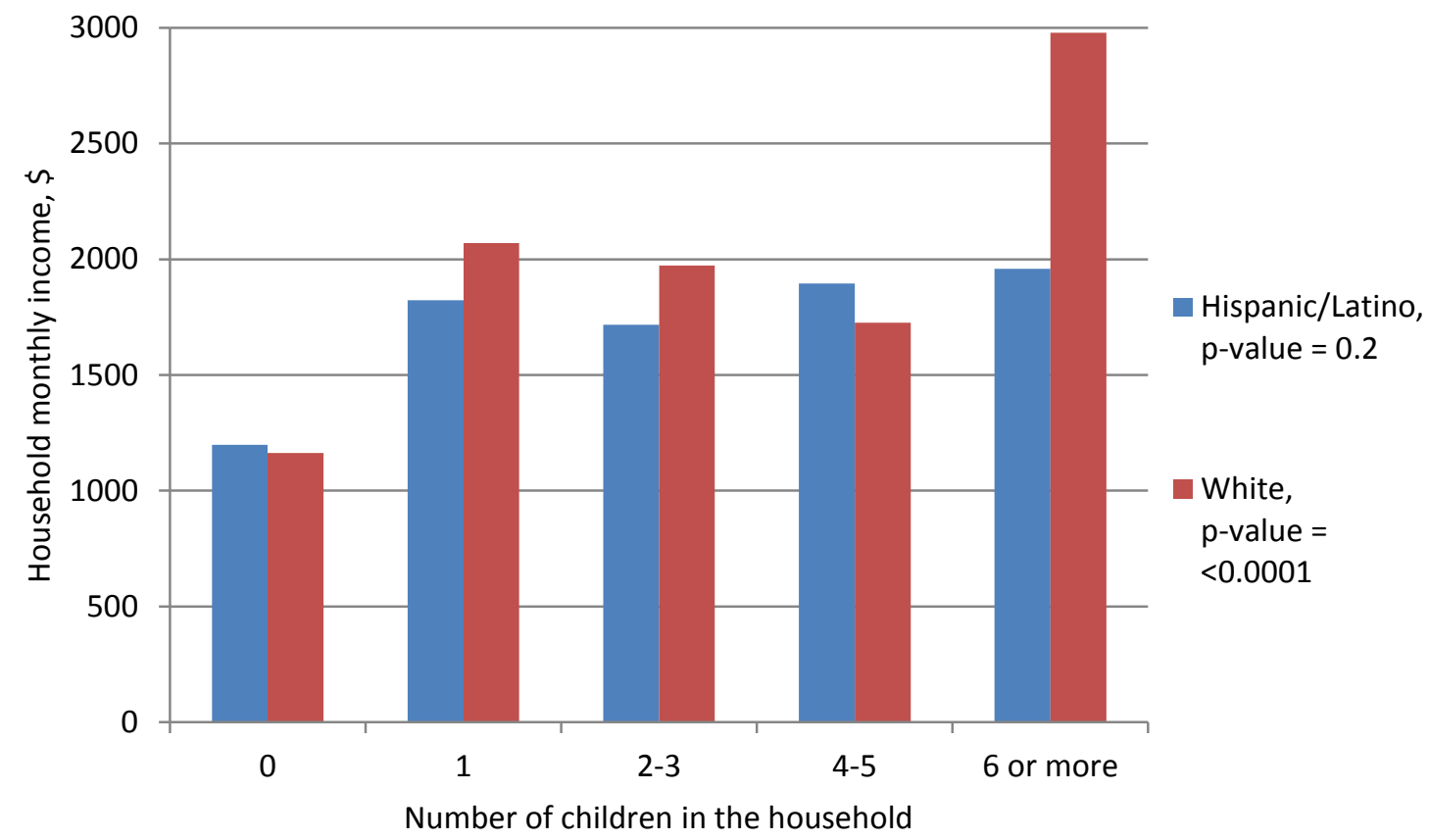

Figure 4-2: Mean household monthly income according to number of children in the household, stratified by ethnicity

Chi-squared test for trend $p=<0.001$ for Hispanic/Latino and $<0.001$ for White

There was an association between education and household income in Hispanic/Latino and White households ( $p=0.01$ for both groups) (Figure 4-3). There was also a linear trend in both groups (Chi-squared test for trend $p<0.001$ for Hispanic/Latino and $<0.001$ for White). Mean income increased significantly between households with an individual in the lowest and highest levels of education ( $\$ 490$ for Hispanic/Latino households and $\$ 600$ for White households), but Hispanic/Latino households had lower income at every category of education. The range of incomes in each education level was wide for both Hispanic/Latino and White households.

Table 4-3 shows the correlation between household income and education. Monthly household income and per capita monthly income were 
positively correlated $(r 0.63, p<0.001)$. Education was significantly correlated with both measures of income but was more strongly correlated with per capita monthly income ( $r 0.29, p<0.001)$.

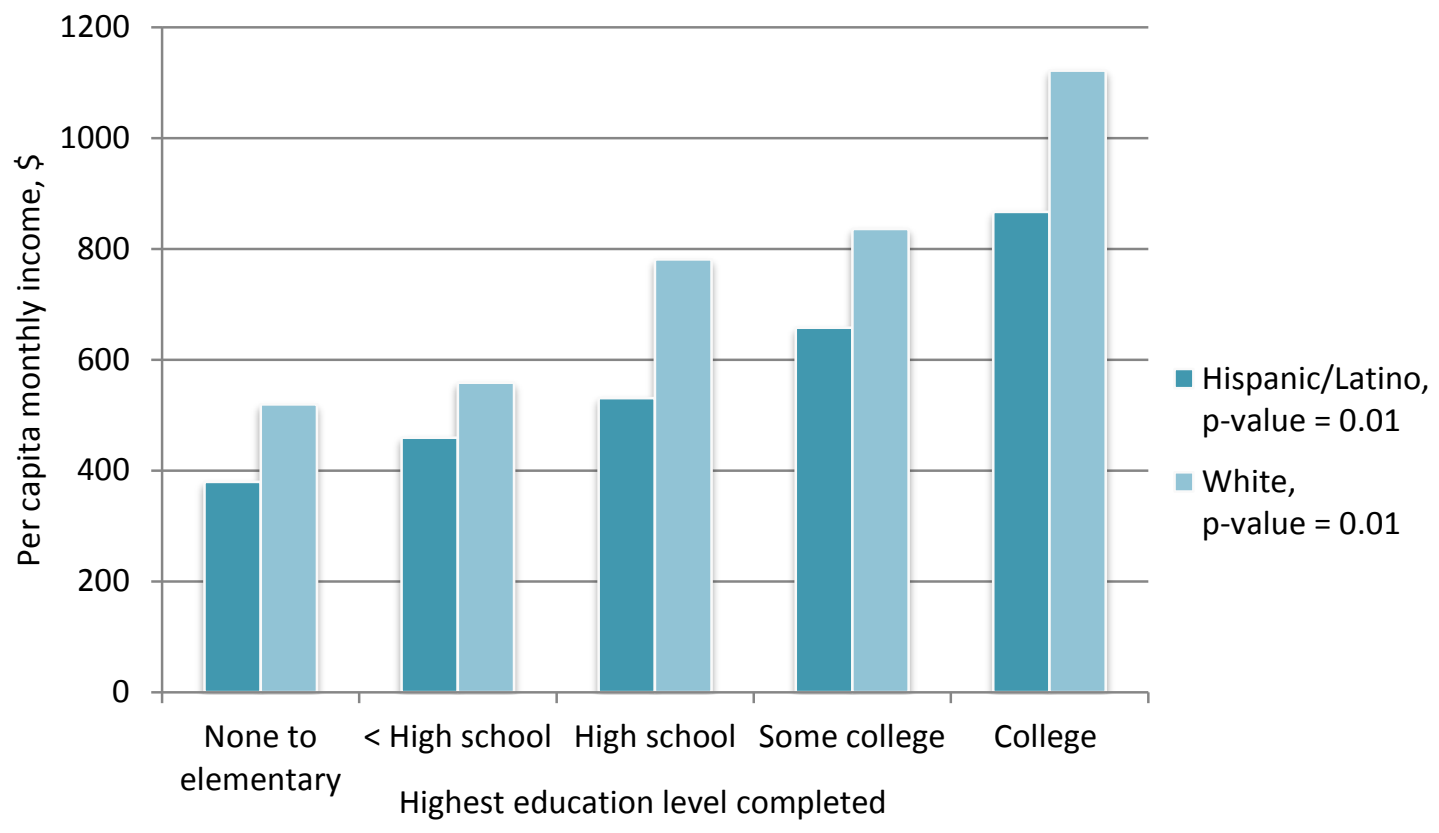

Figure 4-3: Mean per capita monthly income according to highest education level completed, stratified by ethnicity

Chi-squared test for trend $\mathrm{p}<\mathbf{0 . 0 0 1}$ for Hispanic/Latino and $<0.001$ for White

Table 4-3: Correlation matrix of household income (total and per capita) and education

\begin{tabular}{|c|c|c|c|}
\hline & $\begin{array}{l}\text { Monthly household } \\
\text { income }\end{array}$ & $\begin{array}{l}\text { Per capita monthly } \\
\text { income }\end{array}$ & Years of education \\
\hline $\begin{array}{l}\text { Monthly } \\
\text { household } \\
\text { income }\end{array}$ & 1.0 & - & - \\
\hline $\begin{array}{l}\text { Per capita } \\
\text { monthly } \\
\text { income }\end{array}$ & $0.63(p<0.001)$ & 1.0 & - \\
\hline $\begin{array}{l}\text { Years of } \\
\text { education }\end{array}$ & $0.13(p=0.001)$ & $0.29(p<0.001)$ & 1.0 \\
\hline
\end{tabular}


In White households, the number of workers was inversely associated with poverty status $(p=0.003$, Chi-squared test for trend $p<0.001)$. There was no association in Hispanic/Latino households $(p=0.4$, Chi-squared test for trend $p=$ 0.08) (Table 4-4). In Hispanic/Latino households, the type of employment of the primary worker was more significantly associated with poverty $(p<0.001)$ than employment per se (Figure 4-4). The proportion of households living at or below $130 \%$ FPL increased from $56 \%$, in households with a full-time benefited worker to $100 \%$, in households with a seasonal or temporary worker $(p<0.001)$. There was also a large variance in households living in poverty between households with full-time workers who had benefits and those who did not $(56 \%$ and $80 \%$ respectively $p<0.001)$.

Table 4-4: Proportion of households with incomes less than or equal to $130 \%$ of the Federal Poverty Level according to number of workers in the household, stratified by ethnicity

\begin{tabular}{|c|c|c|}
\hline & Hispanic/Latino & White \\
\hline 0 & 88 & 77 \\
\hline 1 & 83 & 66 \\
\hline 2 & 77 & 50 \\
\hline 3 or more & 75 & 25 \\
\hline$p$-value & 0.4 & 0.003 \\
\hline chi-squared test for trend & 0.08 & $<0.001$ \\
\hline
\end{tabular}

$\sim p$-values from Pearson's chi-squared tests 


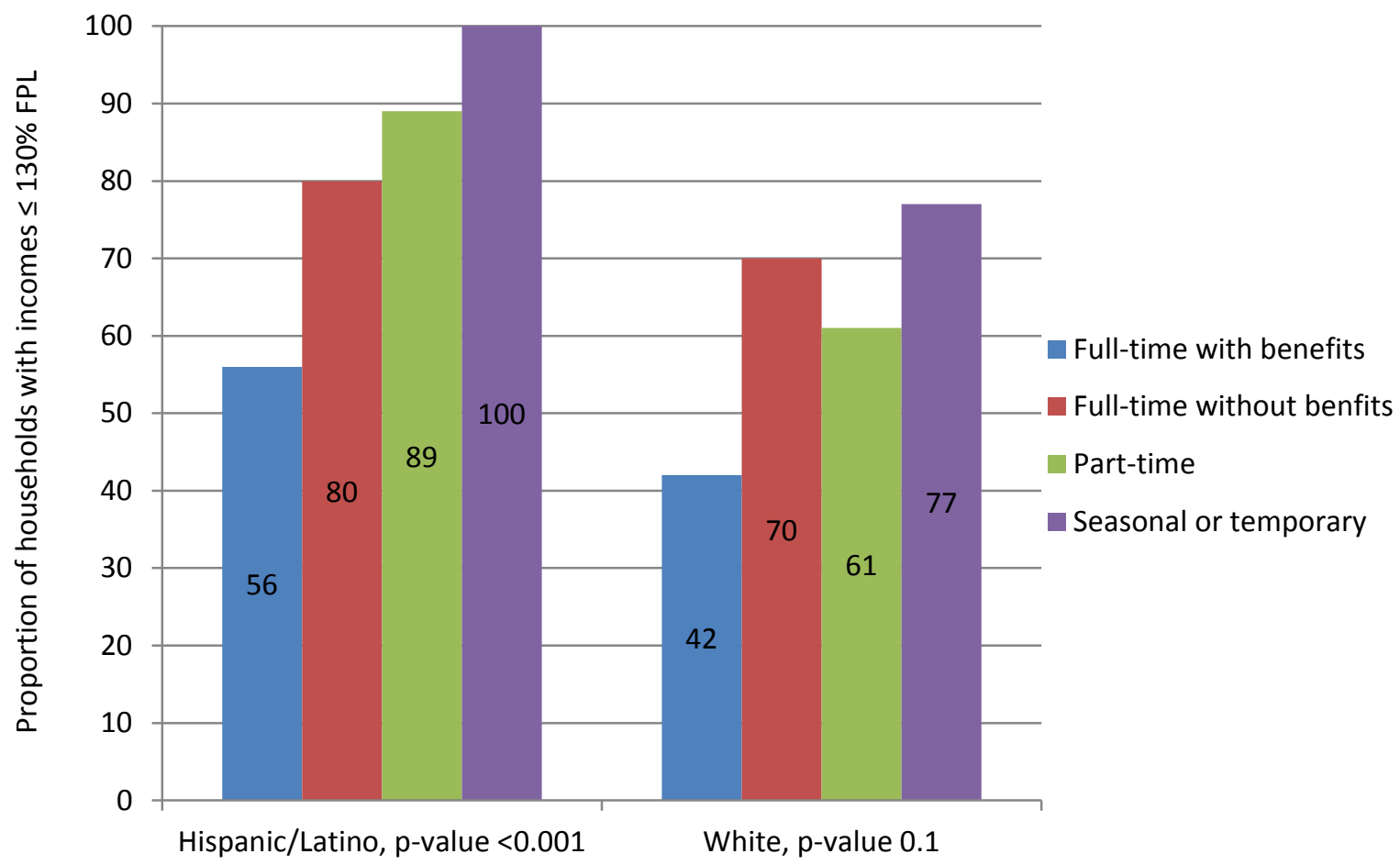

Figure 4-4: Proportion of households with incomes less than or equal to $130 \%$ of the Federal Poverty Level according to type of work, stratified by ethnicity

Chi-squared test for trend $\mathrm{p}<\mathbf{0 . 0 0 1}$ for Hispanic/Latino and $<\mathbf{0 . 0 0 1}$ for White

\section{Food insecurity}

The proportion of households living at or below $130 \%$ FPL varied dependent on food security status in both Hispanic/Latino and White households ( $p<0.001$ for both groups). In Hispanic/Latino households, the proportion of households living in poverty decreased between low and very low food security, whereas in White households the proportion increased (Table 4-5). Per capita income was also associated with food security status in all households $(p<0.001$ for Hispanic/Latino and White, not shown). At each level of food security, Hispanic/Latino households earned less income than White households (not shown). 
Table 4-5: Proportion of households with incomes less than or equal to $130 \%$ of the Federal Poverty Level according to food security classification, stratified by ethnicity High/marginal food security 18

Low food security 46

Very low food security Hispanic/Latino

$\sim$ p-values from Pearson's chi-squared tests

Marital status did not appear to be associated with food security status ( $p$ $=0.2 \mathrm{Hispanic} /$ Latino and 0.1 White). The number of children in the household was associated with food security status in Hispanic/Latino households $(p=$ $0.006)$, but not in White households $(p=0.9)$. Between households with one child and those with two to three, there was a substantial decrease in the proportion of households that were classified as high/marginal food security (30\% to $14 \%$ respectively).

The number of workers in a household was not associated with food security status ( $p=0.5$ for both groups), although in Hispanic/Latino households, type of employment showed a strong association $(p=0.03)$. The proportion of high/marginal food secure Hispanic/Latino households varied greatly between households with a full-time worker with benefits (42\%) and all other employment types (19\% full-time without benefits, $19 \%$ part-time, and $17 \%$ seasonal or temporary employment). 


\section{Logistic regression results}

Tables 4-6 and 4-7 show the associations between food insecurity and age, sex, years of education, marital status, number of children in the household, number of workers in the household, type of work and per capita monthly income in sequentially adjusted logistic regression models. Models were stratified by race/ethnicity based on existing literature and interaction analyses. In sequence, the models control for potentially confounding and mediating variables. There is a sequential decrease in the number of observations in each model due to missing data. In model two, there were 285 observations for Hispanic/Latino households and 319 for White; and by the final model, there were 165 observations for Hispanic/Latino and 99 for White.

\section{Hispanic/Latino households}

Among Hispanic/Latino households, age and sex did not appear to be associated with food insecurity. In the unadjusted model, education was strongly and inversely associated with food insecurity such that with each additional year of education, odds of household food insecurity decreased by $15 \%$ in Hispanic/Latino households (OR $0.85,95 \% \mathrm{Cl} 0.79-0.92$ ). The magnitude of effect and significance levels for education remained similar in all adjusted models.

In the fourth model, adjusted for age, sex, education, marital status and number of children, households with a respondent who reported being single or divorced were more likely to be food insecure compared with households where respondents were married, but confidence intervals were somewhat wide (OR 
1.91, 95\% Cl 0.80-4.55 and OR1.99, 95\% Cl 0.68-5.84, respectively). In subsequent models, households with a respondent who reported being single remained positively associated with food insecurity; however, households with a divorced respondent become negatively associated and these confidence intervals were similarly wide. In the fourth model Hispanic/Latino households with two or three children were 6.23 times $(95 \% \mathrm{Cl} 2.23-16.57)$ more likely to be food insecure than households with no children and households with four or five children were 3.12 times more likely $(95 \% \mathrm{Cl} 1.16-8.39)$. The magnitude of effect for both groups varied somewhat but in all models households with two or three children were the most likely to be food insecure.

As the number of workers in the household increased, odds of food insecurity decreased. However, confidence intervals for all odds ratios included the one and households with zero workers did not fit the model due to lack of sample size. Type of work was strongly associated with food insecurity in the unadjusted model and remained associated in the final model. In the unadjusted model, households with the primary worker employed full-time without benefits or employed part-time, were three times more likely to be food insecure than if the person was employed full-time with benefits $(3.01,95 \% \mathrm{Cl} 1.47-6.17$ and $2.99, \mathrm{Cl}$ 1.06-8.47, respectively). In the fully adjusted model, a difference remained between households with a full-time worker with benefits and a full-time worker without benefits (OR 3.2, 95\% Cl 1.17-8.72) or a part-time worker (OR 3.75, 95\% Cl 0.83-16.88). Per capita monthly income remained associated in all models. In the final model each one-hundred dollar increase in per capita monthly income 
was associated with a decreased risk for food insecurity by $12 \%$ (OR $0.88,95 \%$ Cl 0.78-1.00).

White households

Among White households, the age of the respondent was slightly inversely associated with food insecurity, and odds ratios were near one in all models. Households with a female respondent were at marginally increased odds of being food, especially in model five when age, sex, education, marital status, number of workers and type of work were controlled for (OR 1.64, 95\% Cl 0.604.48).

Marital status was not significantly associated with household food insecurity in any of the models, but in all models, the odds ratio for households with a respondent who reported being single was slightly higher than a household with a married respondent (fully adjusted model OR $2.07,95 \% \mathrm{CI}$ 0.43-9.90). Although not significant, households with a respondent who was widowed appeared to have lower odds of being food insecure than households with a married respondent (fully adjusted model OR $0.46,95 \% \mathrm{Cl} 0.06-3.81$ ). Having any number of children in the household appeared to slightly decrease a households odds of being food insecure, yet odds ratios varied and confidence intervals were wide in all models.

Number of workers in the household was not associated with food insecurity in any of the models. In households with three or more workers, the odds of food insecurity appeared to be lower, yet all confidence intervals were 
wide. Type of work was not strongly associated in any model among White households. Per capita monthly income was associated with food insecurity in the unadjusted model (OR $0.92,95 \% \mathrm{Cl} 0.88-0.96)$. In the fully adjusted model, White households were at $9 \%(95 \% \mathrm{Cl} 0.85-0.98)$ decreased risk for food insecurity per each additional one-hundred dollars of income. 
Table 4-6: Sequentially adjusted logistic regression models for the associations between household characteristics and food insecurity ${ }^{\text {(OR }}$ 95\% CI) (Hispanic/Latino)

\begin{tabular}{|c|c|c|c|c|c|c|}
\hline & 1.Unadjusted & $\begin{array}{l}\text { 2. Adjusted for } \\
\text { age and sex }\end{array}$ & 3. + education & $\begin{array}{l}\text { 4. + marital status } \\
\text { and number of } \\
\text { children }\end{array}$ & $\begin{array}{l}\text { 5. + \# of workers } \\
\text { and type of work }\end{array}$ & 6. + income \\
\hline $\operatorname{Age}^{b}$ & $1.00(0.98-1.02)$ & $1.00(0.98-1.02)$ & $1.00(0.98-1.02)$ & $1.01(0.99-1.03)$ & $1.02(0.99-1.06)$ & $1.04(1.00-1.08)$ \\
\hline \multicolumn{7}{|l|}{$\operatorname{Sex}^{\mathrm{b}}$} \\
\hline Male & (ref) & (ref) & (ref) & (ref) & (ref) & (ref) \\
\hline Female & $0.91(0.50-1.65)$ & $0.84(0.46-1.56)$ & $0.72(0.37-1.40)$ & $0.64(0.31-1.34)$ & $0.73(0.30-1.77)$ & $0.96(0.35-2.63)$ \\
\hline Education, years ${ }^{b}$ & $0.85(0.79-0.92)$ & - & $0.85(0.78-0.92)$ & $0.86(0.79-0.94)$ & $0.85(0.77-0.95)$ & $0.92(0.81-1.05)$ \\
\hline \multicolumn{7}{|l|}{ Marital status ${ }^{\mathrm{b}}$} \\
\hline Married/civil union & (ref) & - & - & (ref) & (ref) & (ref) \\
\hline Single & $0.87(0.46-1.63)$ & - & - & $1.91(0.80-4.55)$ & $1.58(0.54-4.62)$ & $1.94(0.56-6.72)$ \\
\hline Divorced/Separated & $1.17(0.45-3.06)$ & - & - & $1.99(0.68-5.84)$ & $0.77(0.19-3.01)$ & $0.69(0.17-2.84)$ \\
\hline Widowed & $1.53(0.17-13.44)$ & - & - & $2.24(0.20-25.42)$ & $1.75(0.48-6.42)$ & $*$ \\
\hline \multicolumn{7}{|l|}{ Children in household } \\
\hline 0 & (ref) & - & - & (ref) & (ref) & (ref) \\
\hline 1 & $1.81(0.77-4.24)$ & - & - & $2.09(0.79-5.54)$ & $1.75(0.48-6.42)$ & $1.64(0.29-9.32)$ \\
\hline $2-3$ & $4.79(2.23-10.29)$ & - & - & $6.23(2.34-16.57)$ & $4.57(1.40-14.96)$ & $2.44(0.43-13.64)$ \\
\hline $4-5$ & $2.20(1.03-4.70)$ & - & - & $3.12(1.16-8.39)$ & $2.81(0.81-9.73)$ & $1.34(0.21-8.62)$ \\
\hline 6 or more & $4.55(0.92-22.46)$ & - & - & $4.50(0.84-29.87)$ & $4.75(0.65-34.49)$ & $2.11(0.16-27.28)$ \\
\hline \multicolumn{7}{|l|}{ Number of workers in household } \\
\hline 0 & $0.78(0.37-1.66)$ & - & - & - & * & * \\
\hline 1 & (ref) & - & - & - & (ref) & (ref) \\
\hline 2 & $0.72(0.36-1.41)$ & - & - & - & $0.76(0.33-1.75)$ & $0.71(0.27-1.89)$ \\
\hline 3 or more & $0.50(0.21-1.14)$ & - & - & - & $0.52(0.19-1.45)$ & $0.58(0.19-1.81)$ \\
\hline \multicolumn{7}{|l|}{ Type of work } \\
\hline Full- time with benefits & (ref) & - & - & - & (ref) & (ref) \\
\hline Full-time without benefits & $3.01(1.47-6.17)$ & - & - & - & $2.78(1.19-6.50)$ & $3.20(1.17-8.72)$ \\
\hline Part-time & $2.99(1.06-8.47)$ & - & - & 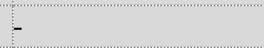 & $3.92(1.01-15.28)$ & $3.75(0.83-16.88)$ \\
\hline Seasonal or temporary & $3.59(1.36-9.50)$ & - & - & 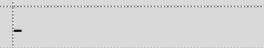 & $2.29(0.76-6.90)$ & $1.89(0.51-7.03)$ \\
\hline Per capita monthly income, 100 's of dollars & $0.84(0.77-0.91)$ & - & - & - & - & $0.88(0.78-1.00)$ \\
\hline
\end{tabular}


Table 4-7: Sequentially adjusted logistic regression models for the associations between household characteristics and food insecurity ${ }^{\mathrm{a}}$ (OR $95 \%$ CI) (White)

\begin{tabular}{|c|c|c|c|c|c|c|}
\hline & 1.Unadjusted & $\begin{array}{l}\text { 2. Adjusted for } \\
\text { age and sex }\end{array}$ & 3. + education & $\begin{array}{l}\text { 4. + marital status } \\
\text { and number of } \\
\text { children }\end{array}$ & $\begin{array}{l}\text { 5. + \# of workers } \\
\text { and type of work }\end{array}$ & 6. + income \\
\hline$\overline{\text { Age }^{b}}$ & $0.98(0.96-0.99)$ & $0.98(0.96-0.99)$ & $0.98(0.96-1.00)$ & $0.98(0.96-1.00)$ & $0.99(0.96-1.03)$ & $0.99(0.94-1.03)$ \\
\hline \multicolumn{7}{|l|}{$\operatorname{Sex}^{b}$} \\
\hline Male & (ref) & (ref) & (ref) & (ref) & (ref) & (ref) \\
\hline Female & $1.20(0.74-1.97)$ & $1.26(0.77-2.08)$ & $1.28(0.77-2.11)$ & $1.50(0.86-2.62)$ & $1.64(0.60-4.48)$ & $1.23(0.35-4.35)$ \\
\hline Education, years ${ }^{b}$ & $0.95(0.86-1.04)$ & - & $0.97(0.88-1.06)$ & $0.97(0.88-1.07)$ & $0.98(0.78-1.22)$ & $0.91(0.70-1.20)$ \\
\hline \multicolumn{7}{|l|}{ Marital status ${ }^{\mathrm{b}}$} \\
\hline Married/civil union & (ref) & - & - & (ref) & (ref) & (ref) \\
\hline Single & $1.84(0.97-3.49)$ & - & - & $1.54(0.77-3.08)$ & $1.60(0.46-5.50)$ & $2.07(0.43-9.90)$ \\
\hline Divorced/Separated & $1.40(0.71-2.76)$ & - & - & $1.42(0.70-2.89)$ & $1.13(0.34-3.75)$ & $1.08(0.27-4.35)$ \\
\hline Widowed & $0.73(0.34-1.55)$ & - & - & $0.85(0.37-1.96)$ & $0.36(0.07-1.89)$ & $0.46(0.06-3.81)$ \\
\hline \multicolumn{7}{|l|}{ Children in household } \\
\hline 0 & (ref) & - & - & (ref) & (ref) & (ref) \\
\hline 1 & $0.78(0.35-1.75)$ & - & - & $0.77(0.33-1.77)$ & $0.72(0.20-2.60)$ & $0.78(0.17-3.59)$ \\
\hline $2-3$ & $1.28(0.58-2.84)$ & - & - & $0.90(0.38-2.16)$ & $0.72(0.21-2.46)$ & $0.51(0.11-2.43)$ \\
\hline $4-5$ & $1.49(0.31-7.20)$ & - & - & $0.76(0.14-4.18)$ & $1.48(0.13-16.60)$ & $0.58(0.04-8.30)$ \\
\hline 6 or more & $0.19(0.02-2.09)$ & - & - & $0.10(0.01-1.21)$ & $0.12(0.01-1.99)$ & $0.91(0.00-1.88)$ \\
\hline \multicolumn{7}{|l|}{ Number of workers in household } \\
\hline 0 & $0.95(0.54-1.66)$ & - & - & - & * & $*$ \\
\hline 1 & (ref) & - & - & - & (ref) & (ref) \\
\hline 2 & $1.01(0.36-2.87)$ & - & - & - & $0.68(0.20-2.29)$ & $1.82(0.32-10.37)$ \\
\hline 3 or more & $0.18(0.02-2.07)$ & - & - & - & $0.16(0.01-2.47)$ & $0.24(0.01-4.36)$ \\
\hline \multicolumn{7}{|l|}{ Type of work } \\
\hline Full- time with benefits & (ref) & - & - & - & (ref) & (ref) \\
\hline Full-time without benefits & $0.95(0.30-3.00)$ & - & - & - & $0.73(0.19-2.75)$ & $0.38(0.08-1.80)$ \\
\hline Part-time & $1.17(0.39-3.50)$ & - & - & - & $1.06(0.29-3.87)$ & $2.05(0.42-10.11)$ \\
\hline Seasonal or temporary & $1.03(0.24-4.41)$ & - & - & - & $0.79(0.14-4.34)$ & $0.65(0.10-4.43)$ \\
\hline Per capita monthly income,100's of dollars & $0.92(0.88-0.96)$ & - & - & - & - & $0.91(0.85-0.98)$ \\
\hline
\end{tabular}

${ }^{\mathrm{a}}$ Food insecurity classified as a dichotomous variable by the USDA 6-item HFSSM

${ }^{\mathrm{b}}$ Individual level data used to represent the household

${ }^{*} \mathrm{n}=0$ 


\section{CHAPTER 5: DISCUSSION}

This study examined marital status, the number of children in the household and the number of workers in the household as potential determinants of household food insecurity. Our findings confirm that some household characteristics were associated with food insecurity among vulnerable Hispanic/Latino and White households, whereas others impacted associated variables. Associations between characteristics and food insecurity varied from Hispanic/Latino to White households in our stratified models. The study design was successful in determining associations among vulnerable and historically under-sampled populations of San Luis Obispo County as evidenced by the high poverty and food insecurity prevalence in the sample. Generally, White households were more educated and earned more income, despite Hispanic/Latino households having more workers and more children.

In this sample, vulnerable Hispanic/Latino and White households had a similar likelihood of being food insecure. This finding is inconstant with national level data (Coleman-Jensen, Nord, Andrews, \& Carlson, 2012). However, because the sample strategy specifically targeted vulnerable groups social and economic disparities were by definition partially controlled for by design. Notwithstanding, income and education levels remained significantly different between Hispanic/Latino and White respondents in our sample, and both were lower than the general population. Although similar in the dichotomous measurement, differences between groups became apparent when considering 
food insecurity in the three category convention. Variable distribution of very low and low food security in the latter classification contributed to this effect.

The primary difference between the two food insecure classifications is that very low food security respondents indicated multiple incidences of disrupted eating patterns and reduced food intake (Table 2-1). A greater proportion of food insecure White households had very low food security, whereas more food insecure Hispanic/Latino households had low food security. This variation may be explained by cultural differences in stress-coping strategies (Farley, Galves, Dickinson \& Maria de Jesus, 2005) or cultural response bias in survey questions (Johnson, Kulesa, Cho \& Shavitt, 2005).

Marital status is likely a more distal variable to food security, which works through a series of associated factors (e.g. income in White households) to modify the outcome. Marital status did not have a direct effect on food security status in either ethnic group; however, marital status was significantly associated with income in White households. White married households had the lowest proportion of households living in poverty and households with a divorced individual had the highest. These trends were not significant in Hispanic/Latino households, suggesting that cultural differences may insulate Hispanic/Latino households from resource disparities in marital status. Strong extended family networks or familismo in Mexican culture (Smith-Morris, Morales-Campos, Alvarez \& Turner, 2012) may contribute to mediating stressors of a singleheaded household that lead to poverty. 
In reference to households with a married respondent, Hispanic/Latino households with a single or divorced respondent were nearly two times more likely to be food insecure. This relationship, however, was not significant and became weaker in sequentially adjusted models, strengthening the notion of a more distal effect of marital status. Among White households, marital status was not significantly associated in any model, yet in all models, households with a respondent who reported being single were more likely to be food insecure than married households. In the fully adjusted models, White households with a widowed individual were much less likely to be food insecure than households with a married individual. This association may be explained by sampling bias. Many surveys collected from potentially widowed individuals were collected at senior living facilities and veteran's halls, where vulnerable White widows may have been more likely to take advantage of supplemental nutrition programs.

Number of children in the household was associated with food security status in Hispanic households; however, number of children was not associated with income. This finding suggests that the mechanisms by which the presence of children affects food security in Hispanic/Latino households occur in a nonlinear fashion, possibly bypassing an effect on household income. According to the hierarchical conceptual framework for this study, number of children could ultimately influence food security status through an effect on level of education, number of workers or type of work. The association between number of children and household income was much stronger among White households than Hispanic/Latino households. As number of children increased in White 
households, income increased, possibly explaining the dissimilar trend in number of children and food insecurity.

After adjustment for age, sex, education, marital status and number of children, Hispanic/Latino households with two or three children were more than six times as likely to be food insecure compared with households with no children. The fact that in the fully adjusted model, households with two to three children remained at the highest risk of being food insecure, even over households with six or more children, suggests that there may be a threshold effect in number of children among Hispanic/Latino households and food insecurity. There was a substantial difference between households with zero and one child and between households with one and two or three children; however after three children, households may acquire skills and coping mechanism that decrease their risk of food insecurity relative to households with only two or three children. This pattern was not duplicated in White households; in fact, having any number of children appeared to slightly decrease households' odds of food insecurity. This relationship, although not significant, may have been a result of a high number of homeless respondents, without children, who self-identified as White. Sixty three White respondents identified as homeless, $92 \%$ without children, compared with 10 Hispanic/Latino respondents who were homeless, $80 \%$ without children.

Number of workers in the household was not associated with food insecurity in either Hispanic/Latino or White households, indicating that employment status per se, was not protective of food insecurity. National and 
state-wide policies have been focused primarily on job creation and unemployment reduction (Office of Governor Jerry Brown, 2011); however, these results suggest that merely having a job is not enough. Employment as a determinant of food security may be associated through terms of the employment (e.g. working hours, salary, and benefit packages). In White households, having more workers was associated with decreased poverty, but this association did not hold in Hispanic/Latino households. This discrepancy in the association between worker number and poverty between White and Hispanic/Latino households is likely a result of differentials in mean per-person earnings by racial/ethnic group (United States Census Bureau, 2011a). In Hispanic/Latino households, type of employment impacted income and also made an important difference in food security status, highlighting the importance of terms of employment, especially among at-risk populations, as mediators of food security.

Results from this study also suggest that other household characteristics were significantly associated with food insecurity. In Hispanic/Latino households, with every additional year of education, risk of household food insecurity decreased by $15 \%(95 \% \mathrm{Cl} 0.77-0.95)$ when adjusted for number of workers and type of work whereas this association was weak among White households. This demonstrates the differential impact, and indeed the real-life value, of education between at-risk Hispanic/Latino and White households. Increased education was also correlated with increased incomes in both groups. However, in each education category White households earned more income than their Hispanic/Latino counterparts. This inequality may point to ethnic differences in 
employment opportunities. Specifically in San Luis Obispo County, the top industries of tourism and agriculture have historically employed many Hispanic /Latino residents (United States Census Bureau, 2011b) and generally offer lower paying jobs with limited benefits.

As expected, per capita monthly income was associated with food security status in both Hispanic/Latino and White households. The relative importance of per capita monthly income remained in the fully adjusted models for both groups. With each increase in one hundred dollars of per capita monthly income, odds of food insecurity decreased in by $12 \%$ Hispanic/Latino households and $9 \%$ in White households. It is important to note that the majority of households were living near or below poverty, suggesting that among poor populations, small changes in income strongly impact risk for food insecurity. Notably, the effect size of these associations was similar in both ethnic groups, reflecting relatively homogenous economic situations between the groups, and the sampling strategy of targeting low-income groups.

One limitation of this study was that some individual data was used in showing associations with household level food insecurity. While respondents were taken to be a representative of their household and it was assumed that individual-level attributes were related to some of the household-level attributes, this may have not always been the case. It was determined that having some information about the respondent, specific persons in the household, and the household as a unit, provided enough information to form conclusions about the household. Another limitation of the study was that in using a logistic regression 
model to analyze odds, a dichotomous outcome variable had to be used, in this case, food insecure or not. Limiting food security status to only the two categories may have been less sensitive to differences in characteristics than the three category classification would have been. Because multiple variables were controlled for in later models of the logistic regression analysis, the number of observations decreased in later models, also making odds ratios less sensitive to detect differences between groups.

One strength of the study was that a unique population was targeted for this investigation. Exclusively sampling at-risk, low-income households made it possible to assess the conditions and needs of a particular population within the County. This type of information is critical to improving community-level food security through local agencies. In addition to targeting vulnerable households, our study was successful in collecting substantial data from the Latino population in the County. More than half of the sample identified themselves as Hispanic/Latino and, more notably, nearly one third of all surveys were collected in Spanish by native Spanish speaking research assistants. Utilizing interviewerapplied surveys by trained research assistants was another strength of the study because it removed reliance on reading skills and ensured quality data collection, and potentially more accurate responses from respondents.

More research is needed on the cultural differences between other ethnic groups, and in different ecologies. While conclusions from this study can be used in better understanding Hispanic/Latino and White households, it is important to consider findings in the context of San Luis Obispo County, which, with its 
distinctive demographics, may make it a special case. It would also be beneficial to investigate cross-cultural differences in survey response patterns to the USDA HFFSM and other measurements tools. Results from this study suggested there were differences in how marital status, number of children and number of workers impacted Hispanic/Latino households and White households, implying that food insecurity among different ethnic groups may manifest and be experienced in unique ways. For this reason, it would be valuable to determine if different ethnic groups interpret and respond to subjective questions about food security differently, and if patterns in their responses are apparent. 


\section{CHAPTER 6: CONCLUSION}

Comprehensive social and economic changes are what will ultimately improve food security in the United States. Several household characteristics determine household food security status and should be considered when approaching reform. In the case of marital status, number of children and number of workers, each either directly or indirectly affects food security. A hierarchical framework of these and other variables predict a series of associations; however those pathways are not necessarily ordered or linear. It is therefore important not to point to one characteristic as the cause of food insecurity, or to simply target one factor in policy strategies.

In planning strategies and policy, it is also valuable to realize that the pathways by which household characteristics impact food security differ between Hispanic/Latino and White households. Different coping strategies and family support networks between racial/ethnic groups should be considered when assessing determinants of food insecurity. Defining social characteristics of racial and ethnic groups should be understood in regards to food insecurity to better customize intervention and policy strategies.

Given the growing population of Hispanic/Latinos in the United States and specifically in California, it is critical to address key characteristics of culturally diverse groups to establish equity among populations. In ethnically diverse areas, such as California, notions of cultural pluralism can promote justice and respect among existing cultural groups. Recognizing the individuality as well as the 
interdependence of different populations may help to bridge gaps in the structural and historical racism which compromise food security and overall health.

Inclusive policies that merge social and economic issues, which consider the multiple determinants of food security in the broader socioeconomic context, may be more complex and could require more resources than one-dimensional strategies. However, this approach is likely to yield more return on investment than current strategies given that rates of food insecurity are increasing despite exorbitant spending on safety net programs. Establishing sustainable food security for all residents should be an economic and social priority for policy makers. With adequate food for an active and healthy life it is more likely that children will meet academic and developmental goals, families will experience better health and stronger relationships and communities will maximize productivity and future human capital. 


\section{WORKS CITED}

Aguirre International. (2005). The California farm labor force: Overview and trends from the National Agricultural Workers Survey. Retrieved from http://agcenter.ucdavis.edu/AgDoc/CalifFarmLaborForceNAWS.pdf.

Alaimo, K., Olson, C.M., \& Frongillo, E.A. (2002). Family food insufficiency, but not low family income, is positively associated with dysthymia and suicide symptoms in adolescents. Journal of Nutrition, 132 (4), 719-725.

Alaimo, K., Olson, C.M., \& Frongillo, E.A. (2001). Food insufficiency and school aged children's cognitive, academic and psychological development. Pediatrics, 108(1),44-53.

Algert, S.J., Reibel, M., \& Renvall, M. (2006). Barriers to participation in the food stamp program among food pantry clients in Los Angeles. American Journal of Public Health, 96(5), 807-809.

American Dietetic Association. (1990). Position of the American Dietetic Association: Domestic hunger and inadequate access to food. Journal of the American Dietetic Association, 90, 1437-1441.

Badun, C., Evers, S., \& Hooper, M. (1995). Food security and nutritional concerns of parents in an economically disadvantaged community. Journal of Canadian Dietetic Association, 56, 75-80.

Basiotis,P.P. (1992). Validity of the self-reported food sufficiency status item in the U.S. American Council on Consumer Interests $38^{\text {th }}$ Annual Conference, Columbia, MO. Washington DC: US Department of Agriculture.

Becker, G.S. (1975). Human Capital: A theoretical and empirical analysis, with special reference to education ( $2^{\text {nd }} E d$.). National Bureau of Economic Research.

Bhattacharya, J., Currie, J., \& Haider, S. (2004). Poverty, food insecurity and nutritional outcomes in children and adults. Journal of Health Economics, 23, 839-862.

Bickel, G., Nord, M., Price, C., Hamilton, W., \& Cook, J. (2000). Guide to Measuring Household Food Security, Revised 2000. Washington DC: 
United States Department of Agriculture.

Blumberg, S. J., Bialostosky, K., Hamilton, W. L., \& Briefel, R. R. (1999). The effectiveness of a short form of the household food security scale. American Journal of Public Health, 89(8), 1231-1234.

Bohn, S. (2011). Public Policy Institute of California. Just the facts: Poverty in California. Retrieved from http://www.ppic.org/main/publication_show.asp?i=261

Braveman, P.A., Cubbin, C., Egerter, S., Williams, D. R., \& Pamuk, E. (2010). Socioeconomic disparities in health in the United States: What the patterns tell us. American Journal of Public Health, 100(S1), S186-S196.

Brown, L.J. (2007). The economic cost of domestic hunger: Estimated annual burden to the United States. Sodexho Foundation.

Capp, R., Horowitz, A., Fortuny, K., Bronte-Tinkew, J., \& Zaslow, M. (2009). Young children in immigrant families face higher risk of food insecurity [Research Brief] (2009-07). Retrieved from http://www.childtrends.org/Files/Child_Trends2009_02_20_RB_ImmigrantFood.pdf.pdf

Carlson, S.J., Andrews, M.S., \& Bickel, G.W. (1999). Measuring food insecurity and hunger in the United States: Development of a national benchmark measure and prevalence estimates. The American Society of Nutritional Sciences, 129(2), 510S-516S.

Casey, P.H., Szeto, K., Lensing, S., Bogle, M., \& Weber, J. (2001). Children in food-insufficient, low-income families: Prevalence, health and nutrition status. Achieves of Pediatric \& Adolescent Medicine, 155(4), 508-514.

Chilton, M., \& Rose, D. (2009). A rights-based approach to food insecurity in the United States. American Journal of Public Health, 99, 1203-1211.

Chaparro, M.P., Langellier, B., Birnbach, K., Sharp, M., \& Harrison, G. (2012). UCLA Center for Health Policy Research. Nearly four million Californians are food insecure [Policy Brief]. Retrieved from http://escholarship.org/uc/item/5407m7mh

Coleman-Jensen, A., \& Nord, M. (September 2012). Definitions of food security. 
Retrieved from http://www.ers.usda.gov/topics/food-nutritionassistance/food-security-in-the-us/definitions-of-food-security.aspx

Coleman-Jensen, A., Nord, M., Andrews, M., \& Carlson, S. (2012). Household food security in The United States in 2011. Washington DC: United States Department of Agriculture, Economic Research Service.

Coley, R.L., Lohman, B.J., Votruba-Drzal, E., Pittman, L.D., \& Chase-Lansdale, P.L. (2007). Maternal functioning, time and money: The world of work and welfare. Child and Youth Services Review, 29(6), 721-741.

Cook, J. T. (2002). Clinical implications of household food security: Definitions, monitoring, and policy. Nutrition in Clinical Care, 5(4), 152-167.

Cuddy, B. (2012, October 12). Ideas for combating hunger in SLO County to be presented to supervisors. The Tribune. Retrieved from http://www.sanluisobispo.com/2012/10/12/2260367/food-bank-hungryfarms.html

Derrickson, J., \& Anderson, J. (2000). Face validity of the core food security module with Asians and Pacific Islanders. Journal of Nutrition Education, 31, 21-30.

Dinour, L.M., Bergen, D.,\& Yeh, M. (2007). The food insecurity-obesity paradox: A review of the literature and the role food stamps may play. Journal of the American Dietetic Association, 107(11), 1952-1961.

Drewnowski, A., \& Specter, S.E. (2004). Poverty and obesity: the role of energy density and energy costs. American Journal of Clinical Nutrition, 79(1), 616.

Ennis, S.R., Rios-Vargas, M., \& Albert, N.G. (2011). The Hispanic population: 2010 [Census Brief]. Retrieved from http://www.census.gov/prod/cen2010/briefs/c2010br-04.pdf

Farley, T., Galves, A., Dickinson, L.M., \& Maria de Jesus, D.P. (2005). Stress, coping and health: A comparison of Mexican immigrants, MexicanAmericans and non-Hispanic whites. Journal of Immigrant Health, 7(3), 213-220.

Food and Agriculture Organization of the United Nations. (June 2006). Food 
security. (Issue 2). Retrieved from

ftp://ftp.fao.org/es/ESA/policybriefs/pb_02.pdf

Food and Agriculture Organization of the United Nations. (2012). Globally almost

870 million chronically undernourished- new hunger report [press release].

Retrieved from http://www.fao.org/news/story/en/item/161819/icode/

Fuller, B., Caspary, G. Kagan, S.L., Gauthier, C., Huang, D.S., Carroll, J., \& McCarthy, J. (2002). Does employment influence poor children's social development? Early Childhood Research Quarterly, 17(4), 470-497.

Frongillo, E.A., Jyoti, D.F., \& Jones, S.J. (2006).Food stamp program participation is associated with better academic learning among school children. Journal of Nutrition, 136, 1077-1080.

Gundersen, C., Lohman, B. J., Eisenmann, J. C., Garasky, S., \& Stewart, S. D. (2008). Child-specific food insecurity and overweight are not associated in a sample of 10- to 15-year-old low-income youth. The Journal of Nutrition, 138(2), 371-378.

Haering, S.A., \& Syed, S., B. (2009). Community food security in the United States cities: A review of relevant scientific literature. Baltimore, MD: Johns Hopkins Center for a Livable Future.

Hamilton, W.L., Cook, J.T., Thompson, W.W., Buron, L.F., Frongillo, E.A., Olson, C.M., Wehler, C.A. (1997). Household food security in the United States in 1995: Summary report of the food security measurement project.

Washington, DC: United States Department of Agriculture.

Hamelin, A., Habicht, J., \& Beaudry, M. (1999). Food insecurity: Consequences for the household and broader social implications. The Journal of Nutrition, 129(2), 525S-528S.

Hazuda, H.P., Stern, M.P., \& Haffner, S.M. (1998). Acculturations and assimilation among Mexican Americans: Scales and population-based data. Social Science Quarterly, 69,687-706.

Hill, K., \& Kaplan, H. (1999). Life history traits in humans: Theory and empirical studies. Annual Review of Anthropology, 28, 397-430.

Hill, K. (1993) Life History theory and evolutionary anthropology. Evolutionary 
Anthropology, 2(3), 78-88.

Hofferth, S., L., \& Anderson, K.G. (2003). Are all dads equal? Biology versus marriage as a basis for paternal investment. Journal of Marriage and Family, 65(1), 213-232.

Hsu, M, Anen, C., \& Quartz, S., R. (2008). The right and the good: Distributive justice and neural encoding of equity and efficiency. Science, 320, 10921095.

Johnson, T., Kulesa, P., Cho, Y.I., \& Shavitt, S. (2005). The relationship between culture and response styles: Evidence from 19 countries. Journal of Cross-Cultural Psychology, 36(2), 264-277.

Jyoti, D.F., Frongillo, E.A.,\& Jones, S.J. (2005). Food insecurity affects school children's academic performance, weight grain and social skills. The Journal of Nutrition, 135(12), 2831-2839.

Kaiser, L.L, Melgar-Quinonez, H., Townsend, M.S., Nicholson, Y., Fuji, M.L., Martin, A.C., \& Lamp, C.I. (2003). Food insecurity and food supplies in Latino households with young children. The Journal of Nutrition Education and Behavior, 35, 148-153.

Kaiser, L. L., \& Townsend, M. (2005). Food insecurity among US children: Implications for nutrition and health. Clinical Nutrition, 20(4), 313-320.

Kaiser, L.L., Melgar-Quinonez, H.R., Lamp, C.L., Johns, M.C., Harwood, J.O., \& Sutherlin, J.C. (2002). Food security and nutritional outcomes of Latino preschoolers. The Journal of American Dietetic Association, 102, 924-929.

Kendall, A., Olson, C.M., Frongillo, E.A., Jr. (1996). Relationship of hunger and food insecurity to food availability and consumption. Journal of the American Dietetic Association, 96(10), 1019-1026.

Kent, G. (2005). Freedom from want: The human right to adequate food. Washington, DC: Georgetown University Press.

Kleinman, R.E., Murphy, J.M., Little, M., Pagano, M., Wehler, C.A., Regal, K., \& Jellinek, M.S. (1998). Hunger in children in the United States: Potential Behavioral and Emotional Correlates. Pediatrics, 101(1), e3.

Lee, J.S., \& Frongillo, E.A. Jr. (2001). Nutritional and health consequences are 
associated with food insecurity among US elderly persons. The Journal of Nutrition, 131(5), 1503-1509.

Lucas, A. (1994). Role of nutritional programming in determining adult morbidity. Achieves of Disease in Childhood, 71, 288-290.

Marmot, M. (2002). The influence of income on health: Views of an epidemiologist. Health Affairs, 21(2), 31-46.

Mazur, R., Marquis, G., \& Jensen, H.H. (2003). Diet and food insufficiency among Hispanic youths: Acculturation and socioeconomic factors in the Third National Health and Nutrition Examination Survey. American Journal of Clinical Nutrition, 78, 1120-1127.

McIntyre, L., Conner, S.K., \& Warren, J. (2000). Child hunger in Canada: Results of the 1994 National Longitudinal Survey of Children and Youth. Canadian Medical Association Journal, 163(8), 961-965.

McLanahan, S. (2001, December). The Consequences of Single Motherhood. The American Prospect. Retrieved from http://prospect.org/article/consequences-single-motherhood.

Morland, K., Wing, S., Diez Roux, A., \& Poole, C. (2002). Neighborhood characteristics associated with the location of food stores and food service places. American Journal of Preventative Medicine, 22(1), 23-29.

National Association of Home Builders. (2012). NABH/Wells Fargo housing opportunity index: $1^{\text {st }}$ quarter 2012 by affordable rank [Data Set]. Retrieved from http://www.nahb.org/reference_list.aspx?sectionID=132

Nazmi, A., \& Lund, A.D. (2012). Hunger-Free communities: Characterizing vulnerable populations in San Luis Obispo County. San Luis Obispo, CA: Science through Translational Research in Diet and Exercise (STRIDE) Program.

Nord, M., \& Hopwood, H. (2007). Recent advances provide improved tools for measuring children's food security. The Journal of Nutrition, 137(3), 533536.

Nord, M. (June 2012). Definitions of food security: CNSTAT Assessment. Retrieved from http://www.ers.usda.gov/topics/food-nutrition- 
assistance/food-security-in-the-us/definitions-of-food-security/cnstatassessment.aspx

Nord, M. (2009). Food Insecurity in households with children: Prevalence, severity, and household characteristics. United States Department of Agriculture, Economic Information Bulletin Number 56. Retrieved from http://www.ers.usda.gov/media/155368/eib56_1_.pdf

Office of Governor Jerry Brown. (2011, August 25). Governor Brown proposes California jobs first package to spur local job creation [Press release]. Retrieve from http://gov.ca.gov/news.php?id=17182

Ohls, J. (1999). Testing the robustness of the Food Security Scale with more recent CPS data. Paper presented at the 2nd Food Security Measurement and Research Conference. Alexandria, VA: United States Department of Agriculture.

Popkin, B., Duffey, K., \& Gordon-Larsen, P. (2005). Environmental influences on food choice, physical activity and energy balance. Physiology \& Behavior, 86, 603-613.

Powell, L., Slater, S., Mirtcheva, D., Bao, Y., \& Chaloupka, F. (2007) Food store availability and neighborhood characteristics in the United States. American Journal of Preventive Medicine, 44, 189-195.

Quinn, T. (2001). Housing issues of new Hispanic residents in lowa. Retrieved from http://www.ncrcrd.iastate.edu/spanishconf/ses3a-housinghandout.html.

Radimer, K.L. (2002). Measurement of household food security in the USA and other industrialized countries. Public Health Nutrition, 5(6A), 859-864.

Reid, K.W., Vittinghoff, E., \& Kushel, M.B. (2008). Association between the level of housing instability, economic standing and health care access: A metaregression. Journal of Health Care for the Poor and Underserved, 19(4), 1212-1228.

Rose, D., \& Bodor, J. N. (2006). Household food insecurity and overweight status in young school children: Results from the early childhood longitudinal study. Pediatrics, 117(2), 464-473. 
Rose, D. (1999). Economic determinants and dietary consequences of food insecurity in The United States. The Journal of Nutrition, 129(2), 517S$520 \mathrm{~S}$

Ryan, K.D. (2010). National Council of La Raza. Profiles of Latino health: $A$ closer look at Latino child nutrition [Policy Brief]. Retrieved from http://www.nclr.org/images/uploads/pages/Jan12_Profiles_Issue_11.pdf

Sano, Y., Garasky, S., Greder, K.A., Cook, C.C., \& Browder, D. (2011). Understanding food insecurity among Latino immigrant families. Journal of Family and Economic Issues, 32(1), 11-123.

Seligman, H. K., Bindman, A. B., Vittinghoff, E., Kanaya, A. M., \& Kushel, M. B. (2007). Food insecurity is associated with diabetes mellitus: Results from the national health examination and nutrition examination survey(NHANES) 1999-2002. Journal of General Internal Medicine, 22(7), 1018-1023.

Shapouri, S., Rosen, S., Peters, M., Tandon, S., Gale, F., Mancino, L., \& Bai, J. (2011). International food security assessment, 2011-21. Washington DC: United States Department of Agriculture-Economic Research Service.

Shetty, P. (2003). Malnutrition and undernutrition. Medicine, 31(4), 18-22.

Skalicky, A., Meyers, A. F., Adams, W.G., Yang, Z., Cook, J.T., \& Frank, D.A. (2006). Child food insecurity and iron deficiency anemia in low-income infants and toddlers in the United States. Maternal and Child Health Journal, 10(2), 177-185.

Smith-Morris, C., Morales-Campos, D., Alvarez, E.,A.,C., \& Turner, M. (2012). An anthropology of familismo: On narratives and description of Mexican/immigrants. Hispanic Journal of Behavioral Science, 35(1), 3560.

Story, M., Kaphingst, K.M., Robinson-O'Brien, R., \& Glanz, K. (2008). Creating healthy food and eating environments: Policy and environmental approaches. Annual Review of Public Health, 29, 253-272.

Tarasuk, V., \& Beaton, G. (1999). Women's dietary intakes in the context of household food insecurity. Journal of Nutrition, 129, 672-679. 
Townsend, M.S., Peerson, J., Love, B., Achterberg, C., \& Murphy, S.P. (2001).

Food insecurity is positively related to overweight in women. The Journal of Nutrition, 131(6), 1738-1745.

Turrell, G. (1996). Structural, material and economic influences of the food purchasing choices of socioeconomic groups. Australian and New Zealand Journal of Public Health, 20(6), 611-617.

United States Census Bureau. (2010). Total fertility rate by race and Hispanic origin: 1980 to 2008 [Data Set]. Retrieved from http://www.census.gov/compendia/statab/2012/tables/12s0083.pdf

United States Census Bureau. (2011a). Historical income tables [Data tables]. Retrieved from http://www.census.gov.ezproxy.lib.calpoly.edu/hhes/www/income/data/ historical/people/

United States Census Bureau. (2011b). Selected economic characteristics: 20072011 American Community Survey-San Luis Obispo County [Data tables]. Retrieved from http://factfinder2.census.gov/faces/tableservices/jsf/pages/productview. xhtml?src=bkmk

United States Census Bureau. (2012a). Selected housing characteristics-San Luis Obispo County, California [Data Set]. Retrieved from http://factfinder2.census.gov/rest/dnldController/deliver?_ts=38333407825 5

United States Census Bureau. (2012b). Poverty status of families, by type of family, presence of related children, race, and Hispanic origin: 1959 to 2011 [Data Set]. Retrieved from www.census.gov/hhes/www/poverty/data/.../hstpov4.xls

United States Census Bureau. (2012c). Marital status of the population by sex, race, and Hispanic origin: 1990 to 2010. [Data Set]. Retrieved from http://www.census.gov/compendia/statab/2012/tables/12s0056.pdf United States Census Bureau. (2012d). A profile of the working poor, 2010. Retrieved from http://www.bls.gov/cps/cpswp2010.pdf 
United States Department of Agriculture. (2009). Access to affordable and nutritious food: Measuring and understanding food deserts and their consequences. Washington, DC.

United States Department of Agriculture. (2011). County-level unemployment and median household income for California, 2011 [Data Set]. Retrieved from http://www.ers.usda.gov/data/unemployment/RDList2.asp?ST=CA

United States Department of Agriculture. (2012a). Hunger-Free Communities Grants. Retrieved from http://www.fns.usda.gov/outreach/grants/hfc_awards.htm

United States Department of Agriculture. (2012b). U.S. Adult Food Security Survey Module: Three-state Design, with Screeners. Retrieved from http://www.ers.usda.gov/datafiles/Food_Security_in_the_United_States/Fo od_Security_Survey_Modules/ad2012.pdf

United States Department of Agriculture, Economic Research Service. (2013). Food desert locator. Retrieved from http://www.ers.usda.gov/dataproducts/food-desert-locator/about-the-locator.aspx

Victora, C.G., Huttly, S.R., Fuchs, S.C., \& Olinto, M.T.A. (1997). The role of conceptual frameworks in epidemiological analysis: A hierarchical approach. International Journal of Epidemiology, 26(1), 224-227.

Vozoris, N.T., \& Tarasuk, V.S. (2003). Household food insufficiency is association with poorer health. The Journal of Nutrition, 133(1), 120-126.

Wehler, C., Scott, R. I., \& Andersen, J. J. (1992). The community childhood hunger identification project: A model for domestic hunger-demonstration project in Seattle, Washington. Journal of Nutrition Education, 24(1), 29s$35 \mathrm{~s}$.

Wilde, P.E. (2004). Differential response patterns affect food-security prevalence estimates for households with and without children. The Journal of Nutrition, 134(8), 1910-1915.

Wilde, P.E., McNamara, P.E., \& Ranney, C.K. (2000). The effect on dietary quality of participation in the food stamp and WIC programs. (Report 9). 
Washington, DC: United States Department of Agriculture, Economic Research Services.

Williams, D. R., \& Jackson, P. B. (2005). Social sources of racial disparities in health. Health Affairs, 24(2), 325-334.

Winicki, J., \& Jemison, K. (2003). Food insecurity and hunger in the kindergarten classroom: It's effect on learning and growth. Contemporary Economic Policy, 21(2), 145-157.

Ziegler J. (2002). Economic, Social and Cultural Rights: The Right to Food. Report by the Special Rapporteur on the right to food: United Nations General Assembly, 58th Session. January 10.

Zizza, C.A., Duffy, P.A., \& Gerrior, S.A. (2008). Food insecurity is not associated with lower energy intakes. Obesity, 16(8), 1908-1913. 


\section{APPENDIX A: Food security assessment survey (English version)}

The Food Bank Coalison of San Luls Oblspo

3TRIDE QQ Calforna Fobtechnic state Univeraty

- "Over the next 2 weeks, volunteers across the county will be doing a survey for The Food Bank Coalition of San Luis Obispo.

- Agencies that serve our community want to ensure that all groups of people are included, especially those that may not have been included in past surveys.

- We need answers from lots of different people.

- Would you be able to spend 15 to 20 minutes of your time to answer some questions about your ability to get the foods that you need?

- Participation is voluntary and you do not have to answer any questions you do not know or do not feel comfortable answering.

- All your answers are completely confidential."

\section{PART 1: SOCIODEMOGRAPHIC INFORMATION}

"First, I would like to ask you some questions about you."

\begin{tabular}{|lrr|}
\hline 1. What is your sex? & $\square$ Male & $\square$ Female $\square$ Other \\
\hline 2. What is your age? & years old \\
\hline 3. Do you consider yourself to be Hispanic or Latino? & $\square$ NO \\
\hline Y YES
\end{tabular}

4. What race do you consider yourself to be? (You may select more than one.)
ㅁ White
ㅁ Native Hawailan or Other Pacific Islander
ㅁ Black or African American
ㅁ Asian
ㅁ. American Indian or Alaska Native
므 Mixed

5. How long have you lived in San Luis Obispo County?
6. How many years have you been living in the United States?
7. What is your marital status? $\quad$ Married $\square$ Single $\square$ Divorcediseparated $\square$ Widowed $\square$ Civil union

"The next questions are about you and your family or the people living with you in the same house."

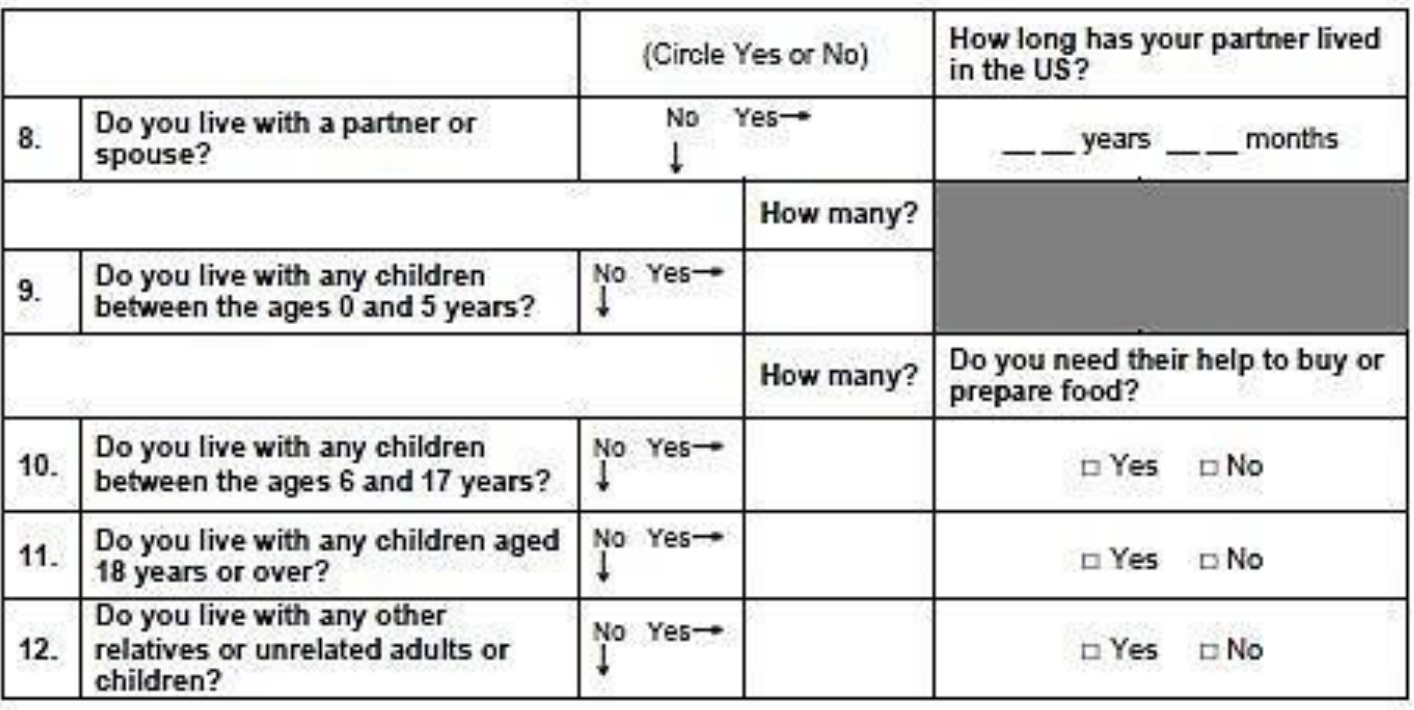




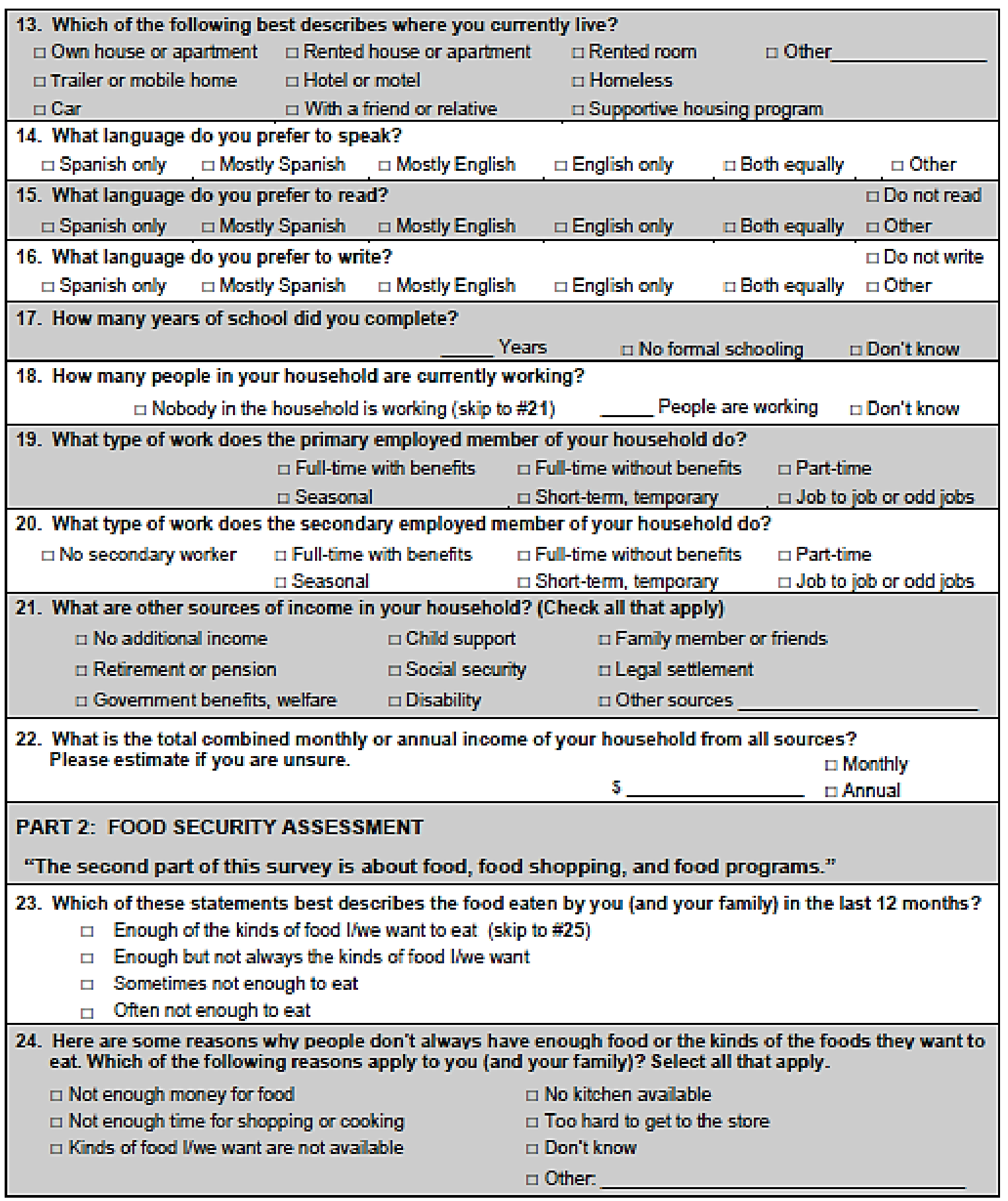


"Now I"m going to read you several statements that people have made about their food situation. For these statements, please tell me whether the statement was often true, sometimes true, or never true for you (and your household) in the past 12 months-that is, since last (name of current month)."

25. The first statement is, "The food that l/we bought just didn't last, and l/we didn't have money to get more." Was that often, sometimes, or never true for you (and your household) in the last 12 months?

$$
\text { 므ten true }
$$

$\square$ Sometimes true

$\square$ Never true

$\square$ Don't know

26. "We couldn't afford to eat balanced meals." Was that often, sometimes, or never true for you (or your household) in the last 12 months?

$$
\square \text { Often true }
$$

$\square$ Sometimes true

$\square$ Never true

口Don't know

27. In the last 12 months, since last (name of current month), did you ever cut the size of your meals or skip meals because there wasn't enough money for food?

$$
\text { ㅁ Yes }
$$

$\square$ No (skip to \#29)

$\square$ Don't know

28. How often did this happen, almost every month, some months but not every month, or in 1 or 2 months? $\square$ Almost every month $\square$ Some months, but not every month $\quad \square$ Only in 1 or 2 months $\square$ Don't know

29. In the last 12 months, did you ever eat less than you felt you should because there wasn't enough money for food?

ㅁes

$\square$ No

$\square$ Don't know

30. In the last 12 months, were you ever hungry but didn't eat because there wasn't enough money for food?

$$
\square \text { Yes } \quad \text { No } \quad \square \text { Don't know }
$$

31. In the last 12 months, how often did you have to choose between buying food and paying rent or mortgage?
Oten
ㅁ Sometimes
$\square$ Never
ㅁ Don't know

32. In the last 12 months, how often did you have to choose between buying food and paying utilities, such as gas, electricity or water?

$\square$ Often

$\square$ Sometimes

$\square$ Never

$\square$ Don't know

33. In the last 12 months, how often did you have to choose between buying food and buying medicine?

$\square$ Often $\quad \square$ Sometimes $\quad \square$ Never

$\square$ Don't know

"Now, I would like to ask you some questions about where you buy food."

34. When you purchase food for your household, where do you buy most of the food? Please select only one $\square$ Larger supermarket

$\square$ Smaller, local grocery store

口Don't know

$\square$ Convenience store or mini-mart

ㅁ Farmer's market or farm stand $\square$ Other.

35. What are the names of the $\mathbf{2}$ stores or markets you most often buy food from?
Name of store:
City:
$\square$ Don't know Name of store:
City:

36. How often do you go food shopping in those stores or markets? times per ㅁ Month

37. How do you get to those stores? Please rank the top 3 forms of transportation, 1 being the most common.

_ Drive your own car Borrow a car Get a ride from somebody with a car _Walk or bike Take the bus/shuttle Other:

38. When you don't prepare a meal at home, what are the names of the $\mathbf{2}$ places or restaurants you most often buy your meals from, including fast-food, drive-thru, pizza, sit-down dining and convenience stores or mini-marts?

Name of restaurant:

City:

$\square$ Don't know Name of restaurant:

City: 
39. How often do you buy fully prepared meals, get take out meals, or eat at restaurants, including fast-food, drive-thru, pizza, sit-down dining and convenience stores or mini-marts? times per $\square$ Week

40. How do you get to those places where you buy fully prepared meals? Please rank the top 3 forms of transportation, 1 being the most common.

_ Drive your own car

- Borrow a car

_ Get a ride from somebody with a car

Walk or bike

Take the bus/shuttle

Other:

41. Some people need outside help in preparing food. This can be a home health aide, a neighbor, or someone from church. Do you have someone that comes to where you live on a regular basis to help with preparing or cooking food?

$\square$ Yes

$\square$ No

口 Don't know

"Next, I would like to ask you how often you eat certain types of food. For each type of food, please tell me how many times you eat it- either per day, per week, or per month."

How often do you eat .......

42. Fruits (fresh, frozen, or canned), such as bananas, oranges. strawberries, or watermelon?

43. Vegetables (raw, cooked, canned, or frozen), such as lettuce, carrots, onions, zucchini, or broccoli?

44. Beans, such as refried beans, bean soup or baked beans?

\begin{tabular}{|l|l} 
& \\
\hline 45. & Meats, including beef, chicken, or pork?
\end{tabular}

46. Dairy products, such as milk, yogurt, or cheese?

47. Soda or sweet drinks such as cola, lemonade, sports drinks, or Kool-Aid?

48. Sweet or salty snacks including candy, cookies, or chips?

\begin{tabular}{|c|c|}
\hline times per & $\begin{array}{l}\text { D Day } \\
\square \text { Week } \\
\square \text { Month }\end{array}$ \\
\hline times per & $\begin{array}{l}\text { DDay } \\
\square \text { Week } \\
\square \text { Month }\end{array}$ \\
\hline times per & $\begin{array}{l}\text { Day } \\
\square \text { Week } \\
\square \text { Month }\end{array}$ \\
\hline times per & $\begin{array}{l}\text { पDay } \\
\square \text { Week } \\
\square \text { Month }\end{array}$ \\
\hline times per & $\begin{array}{l}\text { ㅁ Day } \\
\square \text { Week } \\
\square \text { Month }\end{array}$ \\
\hline times per & $\begin{array}{l}\text { DDay } \\
\square \text { Week } \\
\square \text { Month }\end{array}$ \\
\hline times per & $\begin{array}{l}\text { पDay } \\
\square \text { Week } \\
\square \text { Month }\end{array}$ \\
\hline
\end{tabular}

\section{-.-Please continue to the next page -..}




\begin{tabular}{|c|c|c|c|c|c|}
\hline & (A) & (B) & (C) & (D) \\
\hline & & $\begin{array}{l}\text { Have you heard } \\
\text { of this } \\
\text { program? }\end{array}$ & $\begin{array}{l}\text { Have you ever } \\
\text { used this } \\
\text { program? }\end{array}$ & $\begin{array}{l}\text { Are you } \\
\text { currently using } \\
\text { this program? }\end{array}$ & $\begin{array}{l}\text { Why aren't you } \\
\text { using this } \\
\text { program? } \\
\text { (Use back of } \\
\text { sheet if needed) }\end{array}$ \\
\hline 49. & $\begin{array}{l}\text { Food Stamps, SNAP. } \\
\text { or CalFresh? }\end{array}$ & $\begin{array}{l}\square \text { No } \square \text { Yes } \rightarrow \\
\downarrow\end{array}$ & $\begin{array}{l}\square \text { Yes } \rightarrow \\
\square \text { No (go to part D) }\end{array}$ & $\begin{array}{l}\square \mathrm{No} \rightarrow \\
\square \mathrm{Yes} \downarrow\end{array}$ & \\
\hline 50. & $\begin{array}{l}\text { Places that give free } \\
\text { food, such as the Food } \\
\text { Bank, Meals on } \\
\text { Wheels, churches, or } \\
\text { other places that serve } \\
\text { free cooked meals? }\end{array}$ & $\begin{array}{l}\square \text { No } \square \text { Yes } \rightarrow \\
\downarrow\end{array}$ & $\begin{array}{l}\square \text { Yes } \rightarrow \\
\square \text { No (go to part D) }\end{array}$ & $\begin{array}{l}\text { № } \rightarrow \\
\square \text { Yes } \downarrow\end{array}$ & \\
\hline 51. & WIC? & $\begin{array}{l}\square \text { No } \square \text { Yes } \rightarrow \\
\downarrow\end{array}$ & $\begin{array}{l}\square \text { Yes } \rightarrow \\
\square \text { No (go to part D) }\end{array}$ & $\begin{array}{l}\text { № } \rightarrow \\
\square \text { Yes } \downarrow\end{array}$ & \\
\hline
\end{tabular}

\section{PART 3: COMMUNITY ASSESSMENT}

"For the last part of this survey, I would like to get your opinions on the food situation in your community or neighborhood. Remember that all your responses are confidential."

52. In your opinion, what could be done in our community to reduce hunger and to help families get enough food to meet all their needs? (use back if necessary)

53. Are you willing to provide us with your address to help us study the food environment in your local community and neighborhood? If you do not wish to disclose your street address, please consider providing the nearest cross streets in your neighborhood.

Name of street on which you live (no house number)

$\square$ Do not wish to dlsclose

City:

Zip code:

"Thank you for supporting The Food Bank Coalition of San Luis Obispo County. Your time and insight will help us build a healthier community for everyone."

Interviewer name: Interview date:

Interview location: 


\section{APPENDIX B: Food security assessment survey (Spanish version)}

The Food Bank Coalison of Ban Luls Oblspo

STRIDE Q Calfornla Fobytechnic atate University

- "Durante las próximas dos semanas voluntarios atravéz del condado estarán haciendo una encuesta para la Coalición del Banco de Comida del Condado de San Luis Obispo.

- Agencias que sirven nuestra comunidad quieren asegurarse de que todos los grupos de personas sean incluidos, especialmente aquellos que no hayan podido ser incluidos en encuestas previas.

- Necesitamos respuestas de varios distintos grupos de personas.

- ¿Podría usted tomar 15 a 20 minutos de su tiempo para contestar unas preguntas sobre su habilidad de recibir la comida que usted ocupa?

- Su participación es voluntaria y no es necesario contestar cualquier pregunta que no comprenda o que no sienta cómodo contestando.

- Todas sus respuestas son completamente confidenciales."

PART 1: INFORMACIÓN SOCIO DEMOGRÁFICA

"Primero me gustaría hacerle preguntas sobre usted."

1. ¿Cuál es su sexo?

$\square$ Masculino

$\square$ Femenina $\square$ Otro

2. ¿Cuál es su edad?

$\square$ No $\quad$ a $\mathrm{Si}$

3. ¿Se considera ser Hispano o Latino? 口i

4. ¿A cuál raza se considera usted ser? (Puede seleccionar más de uno.)
ㅁ Blanco
ㅁ Nativo de Hawai o Islas del Pacifico
ㅁ Negro o Africano Americano
ㅁ Asiática
ㅁ Indio Americano o Nativo de Alaska
ㅁ Mixto

5. ¿Por cuánto tiempo ha vivido en el Condado de San Luis Obispo?

6. ¿Por cuántos años ha vivido usted en Los Estados Unidos?

7. ¿Cuál es su estado civil? ¿Casadola $\square$ Soltero/a $\square$ Divorciado/separado $\square$ Viudola $\square$ Unión civil

"Las próximas preguntas son sobre usted y su familia o la gente viviendo con usted en su hogar."

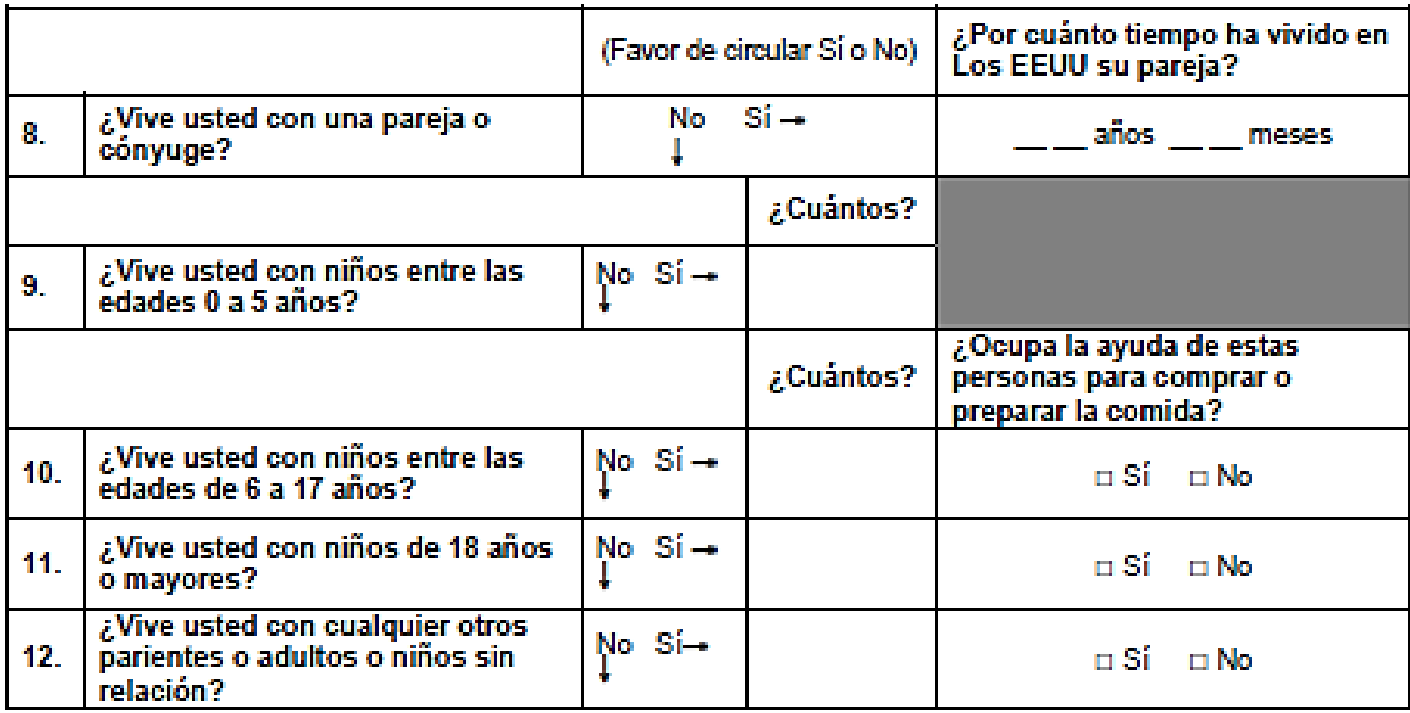




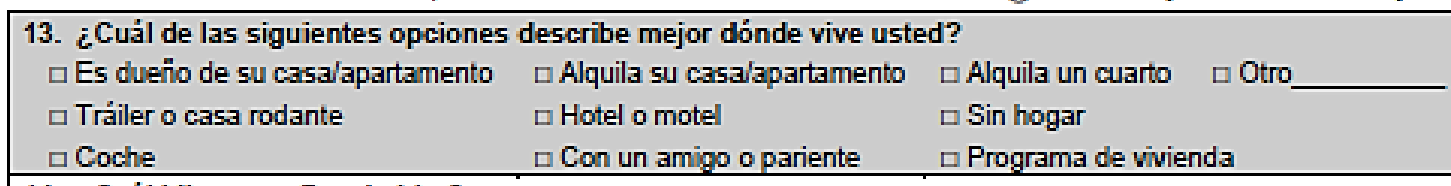

14. ¿Cuál idioma prefiere hablar?

$\square$ Español solamente $\square$ Mayormente Español $\square$ Mayormente Inglés $\square$ Inglés solamente $\square$ Ambos $\square$ Otro

15. ¿Cuál idioma prefiere leer? No sé leer

$\square$ Español solamente $\square$ Mayormente Español $\square$ Mayormente Inglés $\square$ Inglés solamente $\square$ Ambos $\square$ Otro

16. ¿Cuál idioma prefiere escribir?

$\square$ No sé escribir

口Español solamente $\square$ Mayormente Español $\square$ Mayormente Inglés $\square$ Inglés solamente $\square$ Ambos $\square$ Otro

17. ¿Cuántos años de estudios completó usted?

Ar̃os de educación $\square$ Sin educación formal $\square$ No lo sé

18. ¿Cuántas personas en su vivienda están trabajando actualmente?

$\square$ No trabaja nadie en la vivienda (Pase al \#21) Cantidad de personas trabajando

$\square$ No lo sé

19. ¿Qué tipo de trabajo hace el empleado primario de su hogar?

$\square$ Tiempo completo con beneficios $\square$ Tiempo completo sin beneficios $\square$ Tiempo parcial $\square$ Trabajo de Temporada $\square$ A cortó plazo, temporalmente Trabajos ocasionales

20. ¿Qué tipo de trabajo hace el empleado secundario de su hogar?
$\square$ Tiempo completo con beneficios
$\square$ Tiempo completo sin beneficios
口 Trabajo de Temporada
ㅁA cortó plazo, temporalmente
$\square$ Tiempo parcial
Trabajos ocasionales

$\square$ No hay empleado secundario

21. ¿Cuales son las otras fuentes de ingresos en su hogar? (Favor de marcar todos los que apliquen)

$\square$ No hay ingresos adicionales $\quad \square$ Manutención de los hijos $\square$ Miembros de familia o amigos

ㅁ Jubilación o pensión

$\square$ Seguro social

$\square$ Acuerdo legal

$\square$ Beneficios del gobiemo

$\square$ Discapacidad

$\square$ Otras fuentes

22. ¿Cuál es la combinación mensual o anual total de todas las fuentes de ingresos de su hogar? (Favor de mencionar si no está seguro de la cantidad)

ㅁ Mensualmente

$\$$

$\square$ Anualmente

\section{PART 2: EVALUACIÓN DE LA SEGURIDAD ALIMENTARIA}

"La segunda parte de esta encuesta es sobre el alimento, compra de alimentos, y programas de alimentos."

23. ¿Cuál de estas frases describe mejor los alimentos consumidos por usted y su familia durante los últimos 12 meses?

ㅁ Suficiente de los tipos de alimentos que yo/nosotros deseamos comer (pase a \#25)

ㅁ Suficiente pero no todo el tiempo consumimos los alimentos que deseamos

ㅁ A veces no hay suficiente para comer

ㅁ Con frecuencia no hay lo suficiente para comer

24. Aqui hay unas razones por cuál las personas no reciben suficiente comida o no reciben los alimentos que desean. ¿Cuál de las siguientes razones aplican a usted (y su familia)? Favor de seleccionar todas las que se aplican.

$\square$ No hay suficiente dinero para los alimentos $\square$ No hay una cocina disponible

$\square$ No hay suficiente tiempo para ir de compras o para cocinar

$\square$ Las clase de comida que deseo/deseamos comer no está disponible

$\square$ Es muy dificil legar a la tienda

$\square$ Nolo sé

口 Otra razón: 
A continuación le voy a leer varias declaraciones que personas han hecho sobre su situación alimentaría. Por favor dígame si las declaraciones son ciertas con frecuencia, a veces, o nunca para usted (y su familia). Esto sólo incluye los últimos 12 meses desde el pasado (nombre del mes actual)."

25. La primera declaración es, "La comida que compramos no duró lo suficiente y no teníamos dinero para comprar más." Por favor dígame si las declaraciones son ciertas con frecuencia, a veces, o nunca para usted (y su familia). Esto sólo incluye los últimos 12 meses.

$$
\square \text { Con frecuencia } \square \text { Algunas veces } \quad \text { Nunca } \square \text { No lo sé }
$$

26. "Nosotros no teníamos dinero para una dieta balanceada (nutritiva)." ¿Para su casa, en los últimos 12 meses, sucedió esto en su hogar? $\quad$ Con frecuencia $\quad$ Algunas veces $\square$ Nunca $\square$ No lo sé

27. ¿En los últimos 12 meses, usted o algún miembro de su familia comió menos o dejó de comer por que no había suficiente dinero para la comida? 口Si $\square$ No (pase al \#29) $\square$ No lo sé

28. ¿Con qué frecuencia sucedió esto?
$\square$ Casi todos los meses
$\square$ Algunos meses, pero no todos
$\square$ Solo en uno o dos meses
$\square$ No losé

29. ¿En los últimos 12 meses alguna vez tuvo que comer menos de lo que usted piensa necesario porque no hubo suficiente dinero para la comida?

$\square \mathrm{Si}$

$\square$ No

$\square$ Nolo sé

30. ¿En los últimos 12 meses, alguna vez turvo hambre pero no comió porque no tuvo suficiente dinero para comida?

$\square$ Si

$\square$ No

口 No lo sé

31. ¿En los últimos 12 meses con qué frecuencia tuvo que decidir entre comprar alimentos y pagar el alquiler o la hipoteca?

$\square$ Con frecuencia $\quad$ Algunas veces ㅁ. Nunca 모 No lo sé

32. ¿En los últimos $\mathbf{1 2}$ meses con qué frecuencia tuvo que decidir entre comprar alimentos y pagar servicios públicos como el gas, la electricidad o el agua?

$\square$ Con frecuencia $\square$ Algunas veces $\square$ Nunca $\square$ No lo sé

33. ¿En los últimos 12 meses con qué frecuencia tuvo que decidir entre comprar alimentos y comprar medicina?

$\square$ Con frecuencia $\square$ Algunas veces

口 Nunca

口 No lo sé

"Ahora me gustaría hacerle unas preguntas sobre donde compra sus alimentos."

34. ¿Cuándo usted compra alimentos para su hogar, dónde compra la mayoría de sus alimentos?

(Favor de seleccionar solamente uno)
$\square$ Un supermercado
$\square$ Un mercado chico o local
$\square$ No lo sé

$\square$ Mini mercado

$\square$ Mercado de frutas y verduras (mercado de granjero)

口 Otro:

35. ¿Cuáles son los nombres de las dos tiendas/mercados dónde va con más frecuencia a comprar sus alimentos?

Nombre de la tienda:

Ciudad:

口 No lo sé Nombre de la tienda:

Ciudad:

36. ¿Con cuánta frecuencia va de compras a estos supermercados? veces por 口 Semana Mes

37. ¿De qué manera llegas a estos mercados? Favor de clasificar las 3 formas más comunes por las cuál llega al mercado, con 1 siendo el más común.

_ Maneja su propio coche _ Pide prestado un coche _ _ Pide que alguien más lo/la lleve a la tienda _Caminando o en bicicleta _ Por autobús _ Otra:

38. ¿Cuándo usted no prepara la comida en su casa cuales son los nombres de los dos lugares donde acude ir a comprar comida, esto incluye comida rápida, ventanilla de auto servicio, pizza, restaurante, o un mini mercado?

Nombre de restaurante:

Ciudad:

$\square$ No lo sé

Nombre de restaurante:

Ciudad: 
39. ¿Con qué frecuencia compra comida completamente preparada, compra comida para llevar, come en un restaurante; esto incluye comida rápida, ventanilla de auto servicio, pizza o un mini mercado?

veces por

$\square$ Semana $\square$ Mes

40. ¿De qué manera lleqa a estos luqares donde compra comida preparada? Favor de clasificar las 3 transportaciones más comunes por las cuál usted llega a estos lugares, con 1 siendo el más común. Maneja su propio coche Pide prestado un coche _ Caminando o en bicicleta _. Por autobús Pide que alguien más lo/la lleve a la tienda _Otra:

41. Algunas personas ocupan ayuda externa para preparar su comida. Esta ayuda puede provenir de un asistente de salud en casa, de un vecino, o de alguien de un miembro de su iglesia. ¿Tiene usted a alguien que va a su hogar a menudo para ayudarlo/a a preparar o cocinar comida?
口 Si
$\square$ No
$\square$ No lo sé

"Ahora me qustaría prequntarle sobre la frecuencia en cual usted come ciertas clases de comidas. Por cada clase de comida por favor indique cuantas veces come esa clase de comida, así sea por día, por semana, o por mes."

\begin{tabular}{|c|c|c|c|}
\hline \multicolumn{4}{|c|}{ ¿Con qué frecuencia usted come... } \\
\hline 42. & $\begin{array}{l}\text { Frutas (frescas, congeladas, o enlatadas), tal como los } \\
\text { plátanos, naranjas, fresas o sandía? }\end{array}$ & __ veces por & $\begin{array}{l}\text { 口 Dia } \\
\text { ․ Semana } \\
\square \text { Mes }\end{array}$ \\
\hline 43. & $\begin{array}{l}\text { Verduras (crudas, cocidas, o congeladas), tal como la } \\
\text { lechuga, zanahorias, cebollas, calabacitas, o brócoli?? }\end{array}$ & __ veces por & $\begin{array}{l}\text { 口 Dia } \\
\text { ․ Semana } \\
\square \text { Mes }\end{array}$ \\
\hline 44. & $\begin{array}{l}\text { Frijoles, tal como frijoles refritos, caldo de frijol, o frijoles } \\
\text { cocidos? }\end{array}$ & __ veces por & $\begin{array}{l}\text { Dila } \\
\text { ․ Semana } \\
\square \text { Mes }\end{array}$ \\
\hline 45. & Carnes incluyendo el res, el pollo, o el cerdo? & veces por & $\begin{array}{l}\text { पDía } \\
\text { Semana } \\
\text { Mes }\end{array}$ \\
\hline 46. & Productos de leche, tal como la leche, el yogur, o el queso? & veces por & $\begin{array}{l}\text { 마a } \\
\square \text { Semana } \\
\square \text { Mes }\end{array}$ \\
\hline 47. & $\begin{array}{l}\text { Soda, o bebidas dulces tal como la Coca-Cola, limonada, } \\
\text { bebidas de los deportes, o Kool-Aid? }\end{array}$ & - veces por & $\begin{array}{l}\text { Dila } \\
\square \text { Semana } \\
\square \text { Mes }\end{array}$ \\
\hline 48. & $\begin{array}{l}\text { Bocadillos dulces o salados incluyendo dulces, galletas o } \\
\text { chips? }\end{array}$ & __ veces por & $\begin{array}{l}\text { 口 Dia } \\
\text { ․ Semana } \\
\square \text { Mes }\end{array}$ \\
\hline
\end{tabular}

\footnotetext{
-.. - Favor continuar -.. -
} 
"Hay diferentes programas que pueden ayudar miembros de esta comunidad obtener suficiente comida para si mismos o para sus familias. Por cada programa que menciono favor de decirme si usted ha oido de ese programa, si la ha ocupado, o si está utilizando ese programa actualmente."

\begin{tabular}{|c|c|c|c|c|c|}
\hline & (A) & (B) & (C) & (D) \\
\hline & & $\begin{array}{l}\text { ¿Ha oído de ese } \\
\text { programa? }\end{array}$ & $\begin{array}{l}\text { ¿Ha usado ese } \\
\text { programa? }\end{array}$ & $\begin{array}{l}\text { Está usando } \\
\text { este programa? }\end{array}$ & $\begin{array}{l}\text { Por qué no usa } \\
\text { el programa? } \\
\text { (Favor de escribir } \\
\text { atrás si es } \\
\text { necesario) }\end{array}$ \\
\hline 49. & $\begin{array}{l}\text { ¿Las Estampillas de } \\
\text { Comida, SNAP, o } \\
\text { CalFresh? }\end{array}$ & $\begin{array}{l}\square \text { No } \square \mathrm{Si} \rightarrow \\
\downarrow\end{array}$ & $\begin{array}{l}\text { Si } \rightarrow \\
\square \text { No (vaya al D) }\end{array}$ & $\begin{array}{l}\square \mathrm{No} \rightarrow \\
\square \mathrm{Si} \downarrow\end{array}$ & \\
\hline 50. & $\begin{array}{l}\text { ¿Lugares que le dan } \\
\text { comia gratis, como el } \\
\text { Banco de Comida, } \\
\text { Meals on Wheels, } \\
\text { lglesias, u otros } \\
\text { lugares que sirven } \\
\text { comida cocida gratis? }\end{array}$ & $\begin{array}{l}\square \text { No } \square \mathrm{Si} \rightarrow \\
\downarrow\end{array}$ & $\begin{array}{l}\text { Si } \rightarrow \\
\square \text { No (vaya al D) }\end{array}$ & $\begin{array}{l}\square \mathrm{No} \rightarrow \\
\square \mathrm{Si} \downarrow\end{array}$ & \\
\hline 51. & ¿WIC? & $\begin{array}{l}\square \text { No } \square \mathrm{Si} \rightarrow \\
\downarrow\end{array}$ & $\begin{array}{l}\text { Si } \rightarrow \\
\square \text { No (vaya al D) }\end{array}$ & $\begin{array}{l}\square \mathrm{No} \rightarrow \\
\square \mathrm{Si} \downarrow\end{array}$ & \\
\hline
\end{tabular}

\section{PART 3: EVALUACIÓN DE LA COMUNIDAD}

"Para la última parte de esta encuesta me qustaría recibir su opinión sobre la situación alimentaria en su comunidad o vecindad. Recuerde que todas sus respuestas son confidenciales."

52. ¿En su opinión, que se puede hacer en nuestra comunidad para reducir el hambre y para poder ayudar a familias a recibir suficiente comida? (favor de escribir atrás si es necesario)

53. ¿Está usted dispuesto a darnos su dirección para ayudarnos a analizar el ambiente de alimentos en su comunidad local y en su vecindad? Si no desea darnos su dirección, por favor considere darnos el nombre de las calles que se cruzan, más cercanas a su vecindad.

$\square$ No deseo dar esta Nombre de la calle en la que reside? información

(Omite número de vivienda)

Ciudad:

Código postal:

"Gracias por apoyar la Coalición del Banco de Comida del Condado de San Luis Obispo. Su tiempo y perspectiva ayudarán a construir una comunidad más saludable para todos."

Nombre del Entrevistador:

Fecha de la Entrevista:

Localización de la Entrevista: 


\title{
APPENDIX C: Informed consent forms (English and Spanish)
}

\author{
INFORMED CONSENT TO PARTICIPATE IN THE SAN LUIS OBISPO COUNTY \\ FOOD SECURITY ASSESSMENT
}

A research project is being conducted on food availability and food security in San Luis Obispo County. Food Bank volunteers from the San Luis Obispo County Food Bank and students and faculty of California Polytechnic State University are working together to assess the food environment in our communities. Interviewers have been trained by faculty and students from the Department of Food Science and Nutrition and the STRIDE at Cal Poly, San Luis Obispo. The purpose of this study is to assess determinants of food insecurity among certain populations of San Luis Obispo County.

You are being asked to take part in this study by answering a series of questions regarding your household demographics, food shopping, and food intake. Questions will be asked and recorded by a trained surveyor. Your participation will take approximately twenty minutes. Please be aware that you are not required to participate in this research and you may discontinue your participation at any time.

The possible risks associated with participation in this study include some limited social and physiological distress while answering survey questions. If you should feel inconvenienced or offended by the questions asked of you, please be aware that you may contact Dr. Aydin Nazmi (nazmi (a) calpoly.edu or 756-2216) or Dr. Ann Y McDermott (amcdermo@ calpoly.edu or 756-6447) at Cal Poly for questions or assistance.

This survey is completely confidential. Your identity and any identifying personal information will be protected using coding schemes. Your name and other personal identifying information will never be used. Your participation will help provide the Food Bank and other organizations with data to form a more complete picture of food security in our county, benefiting the entire community.

If you have questions regarding this study or would like to be informed of the results when the study is completed, please feel free to contact Dr. Aydin Narmi (nazmi@alpoly.edu or 756-2216) or Dr. Ann Y McDermott (amcdermo@ealpoly.edu or 756-6447) at Cal Poly. If you have questions or concerns regarding the manner in which the study is conducted, you may contact Dr. Steve Davis, Chair of the Cal Poly Human Subjects Committee, at 756-2754, sdavis@alpaly.edu, or Dr. Susan Opava, Dean of Research and Graduate Programs, at 756-1508, sopava@calpoly.edu.

If you agree to voluntarily participate in this research project as described, please indicate your agreement by signing below. Please keep one copy of this form for your reference, and thank you for your participation in this research.

Signature of Volunteer

Signature of Researcher
Date

Date 


\section{El Consentimiento Informado de Participar en la Evaluación de la Seguridad Alimentaria en el Condado de San Luis Obispo}

Un proyecto de investigación se está realizando acerca de la disponibilidad de alimentos y el acceso de la gente a comida en el condado de San Luis Obispo. Voluntarios del Banco De Comida del Condado de San Luis Obispo y estudiantes y profesores de California Polytechnic State University están trabajando juntos para evaluar el ambiente alimentario en nuestras comunidades. Entrevistadores han sido entrenados por los profesores y los estudiantes del Departamento de las Ciencias de la Comida y la Nutrición y del Departamento de Kinesiología y de STRIDE (un equipo de investigación en ciencias de la salud) en Cal Poly, San Luis Obispo. El propósito de este estudio es evaluar determinantes de la inseguridad alimentaria entre ciertas poblaciones en el condado de San Luis Obispo.

Le estamos pidiendo que participe en este estudio contestando una serie de preguntas con respecto a la demografía, compra de alimentos, y ingesta de alimentos en su hogar. Preguntas serán hechas y registradas por un entrevistador entrenado. Su participación se llevará aproximadamente veinte minutos. Por favor, tenga en cuenta que no es necesario participar en esta investigación y puede discontinuar su participación en cualquier momento.

No hay riesgos físicos implicados, pero hay algunas preguntas personales que pueden causar moléstia personal o el estrés. Si usted se siente incómodo u ofendido por las preguntas, por favor esté consciente de que puede ponerse en contacto con el Dr. Aydin Nazmi (nazmi@calpoly.edu o 756-2216) o la Dra. Ann Y. McDermott (amcdermo@calpolyedu o 756-6447) en Cal Poly para asistencia.

Esta encuesta es completamente anónima y totalmente confidencial. No colectamos información personal que puede revelar su identidad. Su participación es importante y ayudará a proporcionar datos al Banco de Comida y a otras organizaciones para formar una imagen más completa de seguridad alimentaria en nuestro condado, beneficiando a todas las comunidades en el área.

Si usted tiene preguntas sobre este estudio o desea ser informado de los resultados cuando se complete el estudio, por favor póngase en contacto con el Dr. Aydin Nazmi (nazmi@calpolyedu o 756-2216) o la Dra. Ann Y. McDermott (amcdermo@calpoly.edu o 756-6447) en Cal Poly. Si usted tiene preguntas o preocupaciones con respecto a la forma en que se hizo el estudio, puede contactar a el Dr. Steve Davis, Director del Comité de los 
Sujetos Humanos de Cal Poly, a 756-2754, sdavis@calpoly.edu , o la Dra. Susan Opava, Decana de Investigación y Programas Posgrados, a 756-1508, sopava@calpolyedu.

Si usted está de acuerdo en participar voluntariamente en este proyecto de investigación como se describe, por favor indique su acuerdo firmando este documento. Por favor guarde una copia de esta forma para su referencia, $y$ gracias por su participación en esta investigación.

Firma de Voluntario

Fecha

Firma de Investigador

Fecha 


\title{
APPENDIX D: Food Security Assessment Survey Training Manual
}

\author{
Hunger Assessment Survey Training Manual
}

\section{1) Background}

a) Procedure at site: Usually large groups of students and other community volunteers will be going to a given site for survey collection but be sure that at any given time you are with at least one other person at a survey site. Follow sign up procedures (as indicated during training) for date and site locations. For each date, at each site, there will be a site leader, who will be the liaison between the interviewers and the site contact. Follow all directions given by your site leader and communicate with them regarding any issues that come up at a site. Make sure that all completed surveys are turned into your site leader prior to leaving the site. Site leaders will vary depending on date and site, so you may come in contact with several different leaders; they will be identified prior to arriving at a site.

b) Sensitivity: This survey targets groups of people in our community who may be at risk of hunger, personally or within their household. It is important, as the interviewer, that you are respectful and unbiased to the different cultures, income levels, living situations, and social backgrounds that you may experience during the interview process. Be aware that this issue of hunger and some questions in this survey can cause embarrassment, anxiety, or discomfort in some interviewees. Be direct and professional with each interviewee, be conscious of your own biases, and be careful never to judge or be perceived as judgmental.

c) Informed consent/confidentiality: After reading the 6 introduction points on the top of the survey it is critical that each interviewee reads and signs the informed consent form (Appendix 1.) Hand the interviewee the appropriate language version of the informed consent form and allow them to read through it and sign it. Familiarize yourself with the document so that you may answer any questions. It is stated in one of the introduction points, as well as in the informed consent form, but it is important that you remember that all answers and even participation in this survey will be kept confidential.

d) Surveyor presentation: On days that you will be conducting interviews, you must wear your red hunger walk Food Bank shirt. The shirts will identify all volunteers at the site. You are responsible for keeping your shirt and having it ready for each interview session that you attend.

2) General Survey Techniques

a) Non -verbal cues: Nonverbal cues, which are any form of communication that is not directly spoken, will occur naturally but should be kept to a minimum and you should keep your cues as neutral as possible.

i) Eye contact: Read the question directly from the survey paper and do not look up to the interviewee. You may make eye contact with the interviewee when it is their time to answer but do not stare and return to the survey once they have answered. 
ii) Facial expressions: Adopt a neural, non judgmental expression for the duration of the interview. Do not express surprise, shock, disdain, disapproval, or disagreement. There is no correct answer to any of the questions.

iii) Tone: Ask each question in a respectful and neutral manner. Do not imply that some answers are "better" than others and do not give less inflection to options you feel are unusual.

b) Reading directly from the survey: Read each question and answer options exactly as it is written on the survey, word for word. Read the quoted prompts and survey questions in the order in which they are presented in the survey. Ask every question specified in the survey; do not omit any questions even if you feel them to be redundant, unclear or inappropriate. Read each question slowly and clearly. Repeat questions or answer options that are misunderstood or unclear in the same manner that you read the question initially. Keep in mind that there are some skip patterns on the survey, which indicate a question should be skipped in the case of some responses.

i) Pause after reading each answer option to give the interviewee a chance to respond to that answer. If they do not acknowledge that as the correct answer, continue reading the other answer options. You may have to read through all answer options before the interviewee responds to a previous answer. You may need to re-read through the full set of answer options before the interviewee responds to an answer.

ii) When reading questions with answer options that indude "don't know" or "other: "DO NOT read these answers aloud as you would read the others. These answers should be marked only if the interviewee voluntarily generates these answers in place of choosing a given answer option.

c) Interpreting Responses: In almost all questions, you will read the answer options below the question. Read these immediately after you have finished reading the question. The interviewee should choose only one option unless it is specified in the question that they may select more than one option. Since most answers cannot be open ended, it is important to isolate the one answer option that applies to the interviewee. This can be difficult if the interviewee answers the question with a story or an answer that is not an option. In this case you may use the following prompts in the example below to isolate an answer option:

i) Question 8: What is your marital status? Answer options: Married, Single, Divorced/Separated, Widowed, Civil union

Interviewee response: Well I was with this guy for 5 years and we had 2 kids and then last month he left me for another woman.

Interviewer prompt: I want to make sure that I am clear; of the given options which would you say most closely reflects your current status? (Reread the answer options) -or-

I see, so of the given options which would you most closely relate to? (reread the answer options] 
Interviewee response: oh, well probably divorced/separated. (Interviewer mark box for divorced/separated.)

\section{3) Specific Sections of the Survey}

\section{a) Part One}

i) Questions 5 and 7: You may enter the response either in the number of years OR the number of months OR both, depending on how the interviewee answers.

ii) Questions 6 and 19: Depending on the answers, you may continue as normal to the next question or follow the skip patterns that direct you to skip some questions and continue at a later question.

iii) Questions 9-13: Follow the arrow prompts to the next question depending on the interviewee response. For example, question 9: "Do you live with a partner or spouse?" If they answer "no," proceed to question 10, if they answer "yes," continue to "was your partner born in the US?" and so on.

iv) For question 23, the interviewee can answer in terms of monthly or annual income, whichever is easier for them, just be sure to check the box of which unit they report in.

b) Part Two

i) Questions 24 and 28: Follow the skip patterns when relevant.

ii) Questions 36 and 39: The interviewee must provide the name and city of a grocery store. This is not from a list and there is no correct answer, simply write whatever they say. Be sure to write clearly.

iii) Questions 38 and 41: The interviewee will have to rank three of the answer options. You should write the numbers 1,2 and 3 on the line next to the chosen options. 1 is the most commonly used form of transportation and 3 is the least.

iv) Questions 43-49: These can be answered in units of days, weeks or months, whichever is easier for the interviewee to recall. Be sure to check the box of which unit is reported. The units do not need to be the same for all questions.

v) Questions 50-52: These questions have several parts but every part may not be answered. Follow the arrow prompts to the next question depending on the given answer. If the interviewee answers "no" to any part B then you will be prompted to skip to part D of the same question. Part D is an open ended question; write out the answer that the interviewee gives you. You may write these responses on the back of the paper if needed. Be sure to note which response corresponds to which number question.

c) Part Three

i) Question 53: This question is opened and requires that you write out the answer given by the interviewee. You may write the response on the back of the paper if needed. Feel free to ask the interviewee to repeat their answer so that you can accurately record it. You can use bullet points if the interviewee has several different ideas. If they don't know or don't want to give a response then write in the answer space "N/A" do not leave the space completely blank. 


\section{Interviewing Procedure Check List:}

1) Warmly greet the interviewee and offer them a seat.

2) Introduce yourself and identify yourself as a food bank volunteer

3) Read the 6 introduction points on the top of the survey

4) If the interviewee agrees to participate, give him/her an informed consent form to read and sign

5) Begin with the quoted sentence under part one, and continue to each question following. Be sure to read all quoted sentences throughout the survey.

6) Upon completing question number 54 , read the closing statement

7) Thank them again for their time.

8) Fill out the interviewer information on the bottom of the last page of the survey

9) Be sure to turn in every survey and informed consent to your site leader 


\section{APPENDIX E: Modified varaibles from the food security assessment for statistical analysis}

\begin{tabular}{|c|c|c|c|}
\hline Modified variable & Change & Original variables used & Notes \\
\hline Age (grouped) & Categorized & Age (continuous) & $\begin{array}{l}\text { Age groupings used in } \\
\text { USDA food security } \\
\text { reporting }\end{array}$ \\
\hline Monthly household income & Standardized & $\begin{array}{l}\text { Household income } \\
\text { (monthly or annual) }\end{array}$ & $\begin{array}{l}\text { Monthly income was a } \\
\text { more practical value for } \\
\text { examining FPL's etc. }\end{array}$ \\
\hline Per capita monthly income & Created & $\begin{array}{l}\text { Monthly household } \\
\text { income and total } \\
\text { number of household } \\
\text { members }\end{array}$ & $\begin{array}{l}\text { Total number of } \\
\text { household members } \\
\text { included the } \\
\text { interviewee, spouse or } \\
\text { partner, any children } \\
\text { and any relatives or } \\
\text { other adults living in the } \\
\text { household }\end{array}$ \\
\hline $\begin{array}{l}\text { Federal Poverty Level cut } \\
\text { offs (100\%, } 130 \% \text {, and } \\
185 \%)\end{array}$ & Created & $\begin{array}{l}\text { Monthly household } \\
\text { income and total } \\
\text { number of household } \\
\text { members }\end{array}$ & $\begin{array}{l}\text { Incomes were classified } \\
\text { based on } 2011 \mathrm{HHS} \\
\text { poverty guidelines }\end{array}$ \\
\hline Education level completed & Categorized & $\begin{array}{l}\text { Years of school } \\
\text { completed }\end{array}$ & $\begin{array}{l}\text { Reported number of } \\
\text { years of school } \\
\text { completed were } \\
\text { grouped into standard } \\
\text { US school education } \\
\text { levels }\end{array}$ \\
\hline Marital status & Categorized & Marital status & $\begin{array}{l}\text { Those who reported } \\
\text { being married or civil } \\
\text { union, were combined } \\
\text { into married/civil union } \\
\text { as a matter of } \\
\text { convention }\end{array}$ \\
\hline $\begin{array}{l}\text { Number of children in the } \\
\text { household }\end{array}$ & Created & $\begin{array}{l}\text { Number of children, by } \\
\text { age group, in the } \\
\text { household }\end{array}$ & $\begin{array}{l}\text { Age of the children was } \\
\text { not relevant in this } \\
\text { analysis, therfore all } \\
\text { ages were combind }\end{array}$ \\
\hline $\begin{array}{l}\text { Number of workers in the } \\
\text { household (grouped) }\end{array}$ & Categorized & $\begin{array}{l}\text { Number of workers in } \\
\text { the household } \\
\text { (continuous) }\end{array}$ & $\begin{array}{l}\text { Any households } \\
\text { reporting } 3 \text { or more } \\
\text { workers were combind } \\
\text { due to a low } n \text { value }\end{array}$ \\
\hline Food insecurity status & Created & $\begin{array}{l}6 \text { USDA HFSSM } \\
\text { questions }\end{array}$ & $\begin{array}{l}\text { Questions were scored } \\
\text { to establish status based } \\
\text { on USDA HFSSM } \\
\text { classifications }\end{array}$ \\
\hline
\end{tabular}

Note. Only variables that were modified from their original form are included. Any variables discussed which are not listed here, were utilized directly as they were collected on the survey (see Methods section) 
